\title{
Conserving seeds of useful wild plants in Mexico: main issues and recommendations
}

\author{
Isela Rodríguez-Arévalo $\cdot$ Efisio Mattana $\cdot$ Lilia García $\cdot$ \\ Udayangani Liu · Rafael Lira • Patricia Dávila • Alex Hudson • \\ Hugh W. Pritchard · Tiziana Ulian
}

Received: 10 September 2015/Accepted: 18 July 2016/Published online: 20 August 2016

(C) The Author(s) 2016. This article is published with open access at Springerlink.com

\begin{abstract}
The efficient storage and germination of seeds underpin the effective use of plants for livelihoods and sustainable development. A total of 204 wild species useful for local communities of the Tehuacán-Cuicatlán Valley were collected and stored in seed banks in country for long term conservation, and $66 \%$ (i.e., 134) duplicated in the U.K., as an effective means of ex situ conservation. Of the 204 species, 147 (122 of which also duplicated in the U.K.) were previously listed as useful plants in the ethnofloristic inventory of the Valley. Based on literature surveys, we found that one of the major impediments to the use of stored seeds of wild species is the lack of knowledge of how to germinate the seed. In detailed studies, we found that seeds of 18 useful plant species from 10 different families germinated readily and could be propagated. In contrast, four species (Actinocheita filicina, Bursera submoniliformis, Karwinskia mollis and Lippia graveolens) produced dormant seeds and therefore further studies are needed
\end{abstract}

I. Rodríguez-Arévalo · L. García · R. Lira · P. Dávila Facultad de Estudios Superiores Iztacala, UNAM, Av. De los Barrios 1, Los Reyes Iztacala, Tlalnepantla,

Estado de México, Mexico

E. Mattana $(\bowtie) \cdot$ U. Liu · A. Hudson .

H. W. Pritchard · T. Ulian

Royal Botanic Gardens, Kew, Wellcome Trust

Millennium Building, RH17 6TN, Wakehurst Place,

Ardingly, West Sussex, UK

e-mail: e.mattana@kew.org before their use can be maximised in large scale propagation programmes in support of conservation and livelihoods. Overall, this large-scale study on useful wild plant species in Mexico confirms that conventional seed banking can effectively support sustainable development and livelihood programmes.

Keywords Drylands - Seed banking $\cdot$ Seed dormancy $\cdot$ Seed germination $\cdot$ Sustainable development

\section{Introduction}

Current global plant diversity extinction is estimated to be as much as 100- to 1000-fold higher than during the recent geological past (Pimm et al. 1995). In situ conservation measures, such as the protection and restoration of natural habitats, are the best methods of preserving plant diversity (CBD 2002). However, ex situ conservation acts as a back-up for certain segments of diversity that might otherwise be lost in nature and in human-dominated ecosystems, generally through the maintenance of clonal crops in field gene banks and in vitro banks, certain trees in conservation stands, and many seed-bearing species in botanic gardens and/or in conventional or cryogenic seed banks (Li and Pritchard 2009). One of the most effective ways to conserve ex situ plant diversity is through germplasm storage in seed banks, which 
allows the preservation of large amounts of genetic material in a small space and with minimum risk of genetic damage (Iriondo and Pérez 1999), at least for species with orthodox (i.e. desiccation tolerant) seeds. Such seeds tolerate drying to very low moisture contents ( $\leq 3-7 \%$ fresh weight), and their longevity increases as moisture content and temperature are reduced (Roberts 1973). In situ and ex situ conservation approaches should be viewed as complementary rather than alternative. However, there are economic drivers working against in situ conservation, with the costs for ex situ conservation being estimated as little as $1 \%$ of those needed for in situ, although ex situ conservation must still address some technical challenges ( $\mathrm{Li}$ and Pritchard 2009).

Seed collecting represents a first critical step of the seed banking process, which should be adressed carefully in order to achieve high quality seed collections, capture the highest genetic diversity of the targeted populations and, at the same time, not pauperize their in situ genetic resources. In particular, seed collections may be affected by high percentages of empty or damaged (by insects or pathogens) seeds (Way 2003).

Once collected, one of the major impediments to the potential use of wild species germplasm for species reintroduction or habitat restoration is the lack of knowledge of how to break seed dormancy and enhance germination (Hay and Probert 2013). Intact viable seeds may fail to complete germination even under favourable conditions and this phenomenon is called "seed dormancy". The primary function of seed dormancy is to prevent germination during periods that are unsuitable for germination and establishment or, more precisely, when conditions are suitable for germination, but the probability of survival and growth of the seedlings is low (Fenner and Thompson 2005). Dormancy is likely to be lost during storage, and the conditions required for germination (in particular, temperature) become less specific (Probert 2000), although the rate of dormancy loss is likely to be slower in seed bank storage than it would be in room conditions (Roberts 1988). During seed bank storage, induction of dormancy can also occur (e.g. Pérez-García et al. 2007) and in the Millennium Seed Bank (MSB) of the Royal Botanic Gardens, Kew (RBG Kew) there have been instances where stored accessions have failed a germination retest carried out using the same treatments and/or conditions that were found to be optimum at the start of the storage (Hay and Probert 2013).

These issues are of particular relevance when working with wild species, whose seed dormancy breaking and germination conditions are unknown or poorly investigated and for which ex situ conservation is intended as a support to their propagation and reintroduction. Useful wild species are still poorly represented in gene banks' collections (Padulosi et al. 2002) whilst ex situ conservation of crop diversity, as a global concern, has received historic support in the development of an efficient and sustainable system recognized in international law and policy, as recently confirmed by the safety duplication collection in the Svalbard Global Seed Vault (Westengen et al. 2013). However, a more recently study concluded that the diversity of crop wild relatives is also poorly represented in gene banks, with over $70 \%$ of taxa identified as high priority for further collecting (CastañedaÁlvarez et al. 2016).

The cultural area known as Mesoamerica (between central Mexico and northern Costa Rica) is recognized as one of the most important centres of cultural diversity and biological richness of the world (Hernández-Xolocotzi 1993; Rzedowski 1993; Toledo et al. 1997). Humans and plants have interacted here for nearly 12,000 years (MacNeish 1992) and such a long and systematic interaction has led to the construction of rich knowledge regarding the use of a wide range of plants. It has been estimated that nearly 5000-7000 species are used in Mexico (Casas et al. 1994). Nearly $90 \%$ of these useful plants are native wild species gathered traditionally (Caballero et al. 1998), whereas nearly 20 plant species (such as corn, beans, cocoa, chili peppers, cotton, and squashes) are important economic crops on a global scale whose extraordinary diversity of landraces and populations of wild relatives constitute highly relevant genetic resources (Lira et al. 2009a).

The Tehuacán-Cuicatlán Valley (Puebla, Central Mexico) is probably the most diverse arid region of North America (Dávila et al. 2002) and it is now an important natural protected area. The relationship between humans and plants in the area is as important today as it has been historically and these interactions, from prehistory to the present day, have been well documented (Casas et al. 2001). Lira et al. (2009a) recorded a total of 1,605 useful vascular plant species (61.2\% of the total species richness of the regional 
vascular flora) for this Valley, which shows the highest absolute richness of useful plants in Mexico.

Since February 2002, the RBG Kew and the Facultad de Estudios Superiores, Iztacala (Fes-I) of the National University of Mexico (UNAM) have been working together for the seed conservation of wild endemic, narrowly distributed, rare and threatened plant species or wild relatives of economically important species from the arid and semiarid areas of Mexico (León-Lobos et al. 2012). This collaboration was established under an Access and Benefit Sharing Agreement (ABSA) in the framework of the MSB Project (lately MSB Partnership). The ex situ conservation and study of useful plants of the arid and semiarid areas of Mexico has been carried out since 2007 through "The Project MGU—the Useful Plant Project" (UPP) under the umbrella of the MSBP. The UPP, managed by RBG Kew, uses an applied scientific approach to conserve and sustainibly use indigenous plants which are important to local rural communities in Mexico, Botswana, Mali, Kenya and South Africa. The project has brought together staff from RBG Kew, and a wide range of national scientific institutions, to help local communities tackle the environmental challenges threatening their livelihoods through the conservation and sustainable use of indigenous plant species (Ulian et al. 2016). The UPP in Mexico has been led by Fes-I UNAM, based in Mexico City, and has worked in the Coxcatlán municipality (Puebla) in the TehuacánCuicatlán Valley. Seeds were collected and stored at the Fes-I Seed Bank and duplicated at the RBG Kew's MSB in the U.K. Propagation activities were carried out at the Fes-I UNAM and replicated in the local communtity, in the framework of the project.

Therefore, the aim of this paper was to evaluate the contribution of seed banking and germination studies on the conservation of useful wild plants as a support to sustainable development and livelihood programmes.

\section{Materials and methods}

Study area

The study area was limited to the Coxcatlán municipality in the Tehuacán-Cuicatlán Valley and in particular to the villages of San Rafael, San José
Tilapa and Guadalupe Victoria, in the state of Puebla (Central Mexico). This area, which covers ca. $6 \mathrm{~km}^{2}$, is located at ca. $1200 \mathrm{~m}$ a.s.l., and the local climate is semi-arid to arid. The mean annual temperature is $22{ }^{\circ} \mathrm{C}$, varying between $25{ }^{\circ} \mathrm{C}$ in April and May, and $18{ }^{\circ} \mathrm{C}$ in January. Rainfall is concentrated in the summer, from June until September and the total annual precipitation is $394.6 \mathrm{~mm}$ (Medina 2000). The main communities originated from the state of Oaxaca and southern Puebla. Their understanding of the local natural resources grew through the adoption of knowledge from neighbouring villages and the discovery of new uses of the local species (Rosas 2003). The most important economic activity in the region is the production of sugarcane, beans, squashes and maize, which is complemented by the gathering of wild plants and insects (e.g. "cocopaches", Thasus sp., Coreidae) for direct consumption or commercialization (Pardo 2001).

\section{Seed banking}

The ethnofloristic inventory carried out by Lira et al. (2009a) for the whole Tehuacán-Cuicatlán Valley was used as a reference of useful plants present in the study area. This inventory originally counted 1605 useful plants belonging to 671 genera and 147 families (Lira et al. 2009a). For the purpose of this study, only vascular plants were considered and the list was nomenclaturaly checked and updated according to The Plant List (2013). In addition, the desiccation tolerance of the seeds of these species were evaluated using the Seed Information Database, SID (Royal Botanic Gardens Kew 2014) so that species with (or likely to have) intermediate or desiccation sensitive seeds were discarded. This led to a total of 1,162 useful vascular plants, belonging to 578 genera and 111 families, with a putative orthodox seed storage behaviour (see Appendix 1).

From 2007 to date, seed collection expeditions have been carried out in the study area as an activity of the UPP (Ulian et al. 2016). Ethnobotanical, biological, and ecological information on useful plants was documented by consultations with local communities and through literature reviews (e.g. Lira et al. 2009a). Plants with a putative orthodox seed storage behaviour (see Appendix 1) were then prioritized for seed collecting, although opportunistic collections were also made on other useful native wild species 
identified in the study area. The choice of the optimal timing for seed collection, as well as harvesting methods and quantity of material to be collected, were regulated by legal (ABSA), ethical and scientific criteria that guarantee a high quality of the collected material (Way 2003) and avoided the pauperization of the in situ genetic resources (Menges et al. 2004).

The collected seeds have been stored in the Fes-I UNAM Seed Bank. Seeds of species for which a seed desiccation sensitive behaviour is reported, or could be inferred, were not collected, while collected seed lots have been banked following the procedures for orthodox seeds (Terry et al. 2003). Once in the bank, after the samples had been registered, seeds were stored in the lab $\left(23{ }^{\circ} \mathrm{C}\right.$ and R.H. $\left.28 \%\right)$ and cleaned manually and mechanically by a gravimetric separator (Mod. CB-1, Agriculex Inc.). Priority for the cleaning was given to fresh fruits for which seeds are separated from the pulp under running tap water and then left to dry. To achieve seed moisture content values between 3.5 and $6.5 \%$ (Linington 2003) viable seeds were then placed in the dry room (T $14{ }^{\circ} \mathrm{C}$ and R.H. $11 \%$ ) for 4-6 weeks and then stored at $-20{ }^{\circ} \mathrm{C}$ in aluminium bags. Duplicates of seed lots (when enough seeds were available) were sent after drying to the MSB (U.K.) for backup storage and testing.

In country germination experiments

Seed lots were tested for germination at Fes-I UNAM Seed Bank using an incubator (ICP-18 d-c/iv Lumistell ${ }^{\circledR}$ ) set at the constant temperature of $30^{\circ} \mathrm{C}$ and a photoperiod of $12 \mathrm{~h}$ of irradiance per day (with 10 white neon lights corresponding to 5100 lux). The incubation temperature is coherent with the requirement of high germination temperatures for species of hot deserts and semi-deserts, which range, according to their life forms, from ca. 20 to ca. $27^{\circ} \mathrm{C}$ for annuals and vines, respectively (Baskin and Baskin 2014). This pattern was recently confirmed by OrdõnezSalanueva et al. (2015), who identifed an optimum temperature for germination rate of ca. $30{ }^{\circ} \mathrm{C}$ for seeds of two Polaskia species collected in the study area (Puebla, Tehuacán-Cuicatlán Valley). Light requirement for seed germination is reported to be related to seed mass, with seeds smaller than $1.5 \mathrm{mg}$ likely to require light for germination (Jankowska-Blaszczuk and Daws 2007). Seed mass of the collected species ranged from ca. $0.05 \mathrm{mg}$ to ca. $1.2 \mathrm{~g}$ for Nicotiana glauca and Proboscidea louisianica, respectively (Royal Botanic Gardens Kew 2014), with $25 \%$ of the collected species having a seed mass $\leq 1.5 \mathrm{mg}$ (data not shown).

Cleaned seeds were sown on the top of one sheet of filter paper, in 60- or 90-mm-diameter glass Petri dishes (3 replicates of 20 seeds each), according to seed size. Seeds were sown without any pre-treatment except for those of Leguminosae which were chipped before sowing to break physical dormancy and allow water imbibition. Germination was defined as visible radicle emergence to $\geq 1 \mathrm{~mm}$ and germinated seeds were scored three times a week. Germination tests lasted 20 days and then at the end of the test, a cut-test was carried out to determine the viability of the remaining seeds. Soft, mouldy seeds were considered to be non-viable.

\section{Seed testing at RBG Kew's MSB}

Seed lots duplicated at the RBG Kew's MSB were tested after cleaning for seed lot quality and germination and viability. In order to estimate seed lot quality, empty or insect-infested seeds present in a subsample (approximately 50 seeds) of the whole seed lot were evaluated using a MX20 Faxitron X-ray unit, with a $<20 \mu \mathrm{m}$ focal spot and $5 \times$ geometric magnification (Faxitron Bioptics, LLC, Tucson, Arizona).

Seed germination was assessed about 1 month after storage at $-20{ }^{\circ} \mathrm{C}$. The number of seeds in each treatment sample was usually 20 or 50 seeds, according to seed availability. For very small collections, as few as 10 seeds were used although seed lots with less than 500 good quality seeds were left untested. Seeds were sown on $1 \%$ water agar in plastic Petri dishes and then placed at an appropriate temperature in an illuminated incubator ( $8 \mathrm{~h}$ fluorescent light/16 h dark). Germination (usually to $\geq 1 \mathrm{~mm}$ protrusion of radicle) was recorded weekly and the germinated seeds removed and discarded. When no germination occurred during 2 weeks following 4 weeks of testing, the test was terminated and the remaining seeds evaluated by a cuttest to ascertain whether they were full, empty or mouldy. Soft, mouldy seeds were considered to be nonviable. The particular germination conditions to break seed dormancy for the investigated species (gibberellic acid in the substrate, scarification or stratification treatments) were chosen according to data accumulated previously at the RBG Kew and by information from literature (Terry et al. 2003). 
Data analysis

The representativeness of each family in the inventory of useful plant families of the Tehuacán-Cuicatlán Valley (Appendix 1) was calculated as the percentage of useful species in the family against the total number of species in the inventory. The representativeness of each useful plant family against the total useful species stored at the Fes-I Seed Bank was calculated in the same way.

According to Godefroid et al. (2010), the dormancy status was determined using the following equation (Offord et al. 2004):

$$
\begin{aligned}
& \text { Dormancy Index }(\mathrm{DI}) \\
& \quad=1-(\text { seed germinated } \% / \text { viable seeds } \%) .
\end{aligned}
$$

The percentage of germinated seeds was calculated on the basis of tested viable seeds. For the purpose of this study this index does not include physical dormancy as seeds of species for which this was assumed (i.e. Leguminosae) were scarified before sowing for germination. The higher the value of the index the more likely that the seed lot was dormant, and DI $\geq 0.4$ was used as threshold value to indicate dormancy (Offord et al. 2004).

Simple linear regressions were fitted to identify correlations among the most important families of the Tehuacán-Cuicatlán Valley and those stored at the Fes-I UNAM Seed Bank and between the DI values achieved for each species at both the RBG Kew's MSB and Fes-I UNAM. Statistical analysis were carried out using R v. 2.14.1 (R Development Core Team 2011).

Uses of species were compiled from Lira et al. (2009a) and complemented by field observations through during the UPP. The standardization of plant uses followed the first level of uses in the "Economic Botany data collection standards" (Cook 1995) revised together with the author of the standardization through the work of the UPP.

\section{Results}

Seed conservation

The families of the Tehuacán-Cuicatlán Valley which had most useful plants with orthodox seeds, were
Poaceae, Leguminosae, Compositae, Cactaceae, Cyperaceae, Solanaceae, Euphorbiaceae, Malvaceae, Asparagaceae and Crassulaceae. Figure 1A reports their proportions, expressed as a percentage of the species in each family relative to the total number of species of the inventory of useful plants (Lira et al. 2009a, modified; Appendix 1). During the UPP, a total of 204 useful plant species, from 142 genera and 48 families, were collected and stored at the Fes-I UNAM Seed Bank. Of these, 147 (belonging to 104 genera and 36 families) are included in the inventory of useful plants (Appendix 1). Therefore ca. $12 \%$ of the useful plants of the whole Tehuacán-Cuicatlán Valley is currently stored for long term conservation at the Fes-I UNAM Seed Bank. Furthermore, 134 taxa from 101 genera and 40 families are also duplicated at the RBG Kew's MSB and 122 of them (belonging to 91 genera and 36 families), included in the inventory of useful plants (Appendix 1).

The representativeness of the most important families of the Tehuacán-Cuicatlán Valley in the Fes-I Seed Bank, calculated as percentage of species in respect to the total of useful species stored at the seed bank, is reported in Fig. 1b. Representativeness of the useful plant families on the inventory and that of those stored at the Fes-I UNAM Seed Bank had the same trend $\left(\mathrm{R}^{2}=0.25 ; p=0.0008 ; y=0.44 x+\right.$ $1.49 ; \mathrm{n}=41$ ), except for the Poaceae and Cyperaceae which are underrepresented and the Cactaceae which are overrepresented (Fig. 1B). A linear regression carried out without Poaceae and Cyperaceae confirmed this correlation $\left(\mathrm{R}^{2}=0.89 ; \quad p<0.0001\right.$; $\mathrm{n}=39)$, with a $x$ coefficient close to 1 ( $\mathrm{a}=1.25$; Fig. 1B).

Uses

All the main categories of uses were represented by the species stored at the Fes-I Seed Bank. The most represented are species with environmental uses (22.3\%), followed by species used as medicines (18.7\%), fodder (animal food, $16.2 \%$ ) food (15.7\%) and materials (Fig. 2A). In Fig. 2B the records of uses are grouped for each of the 10 most important useful plants families (see Fig. 1A).

Leguminosae is the family with the highest number of records of uses (62), followed by Cactaceae (42), 

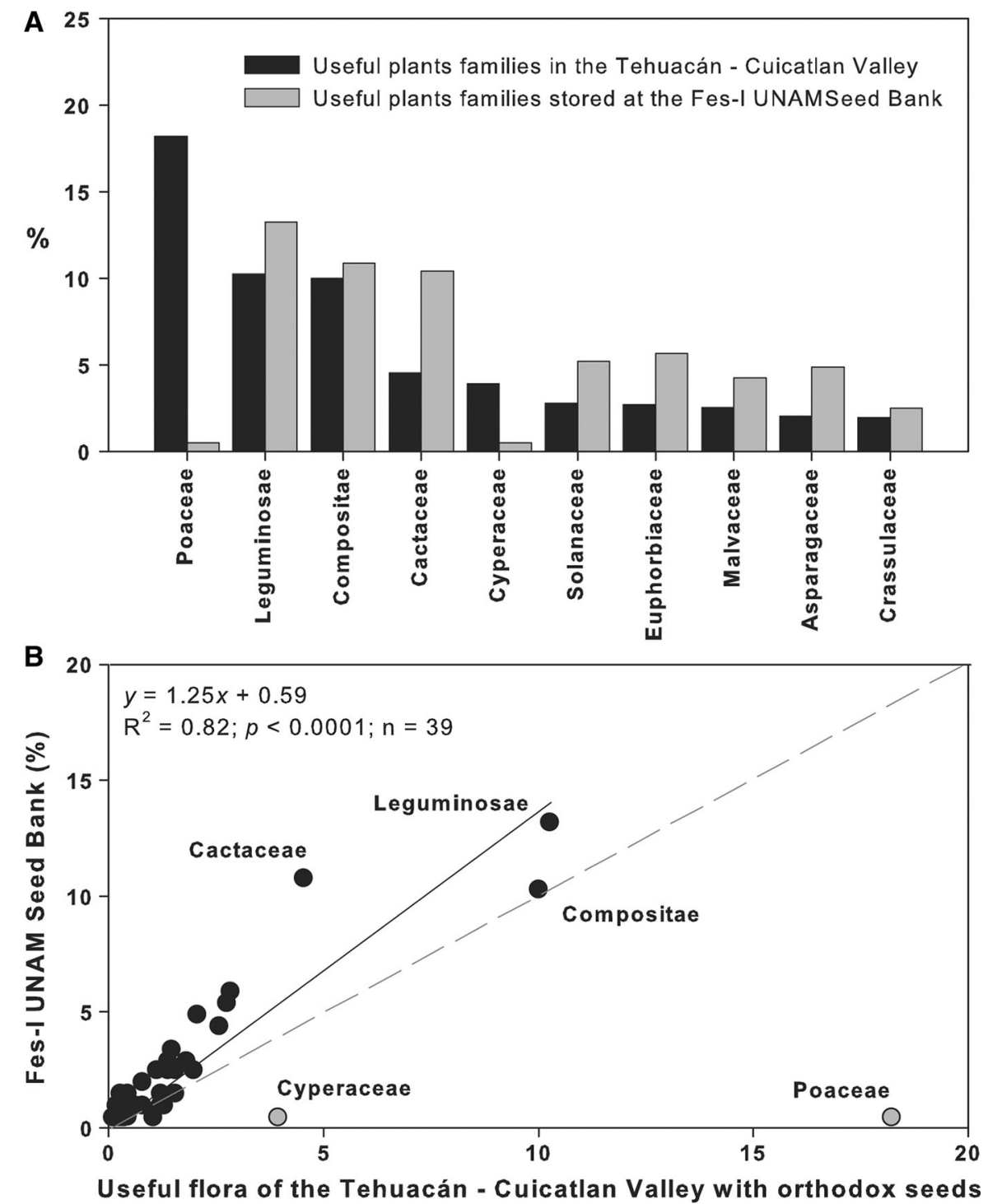

Fig. 1 A The 10 most important families of the TehuacánCuicatlan Valley according to their representation in the bankable useful flora (i.e. species with orthodox seeds) of the Tehuacán-Cuicatlán Valley (see Appendix 1) and their representativeness in the Fes-I UNAM Seed Bank collections. Data are expressed as percentages of the total number of useful species in the inventory and of that of useful species stored at the Fes-I UNAM. B Correlation between representativeness of the most important families according to their richness in useful

Compositae (39) and Asparagaceae (29; Fig. 2B). Cactaceae is the family with the highest number of species used as food, Leguminosae and Compositae have the most species used as medicines and Asparagaceae has most used as materials (Fig. 2B). plants (Appendix 1: Lira et al. 2009a, modified) and that of families stored at the Fes-I UNAM Seed Bank. Data are expressed as percentages of the total number of useful species in the inventory (Lira et al. 2009a, modified) and of that of useful species stored at the Fes-I UNAM Seed Bank. Linear regression was calculated without considering the values of Cyperaceae and Poaceae (grey circles); $\mathrm{n}=39$. The five most important useful plant families have been labelled (see Fig. 1) and the 1:1 line has also been plotted in the graph

Seed lot quality

The $\mathrm{X}$ ray analysis was carried out on seed lots of 72 species duplicated at the RBG Kew's MSB. Only 11 taxa (which correspond to the $15 \%$ of the analysed 
Fig. 2 Uses of the plants stored at the Fes-I UNAM Seed Bank. A Uses grouped according to the first level of Economic Botany data collection standards (Cook 1995 , modified) as percentages of records in relation to the total.

B Records of uses for each of the most important useful plant families of the Tehuacán-Cuicatlan Valley

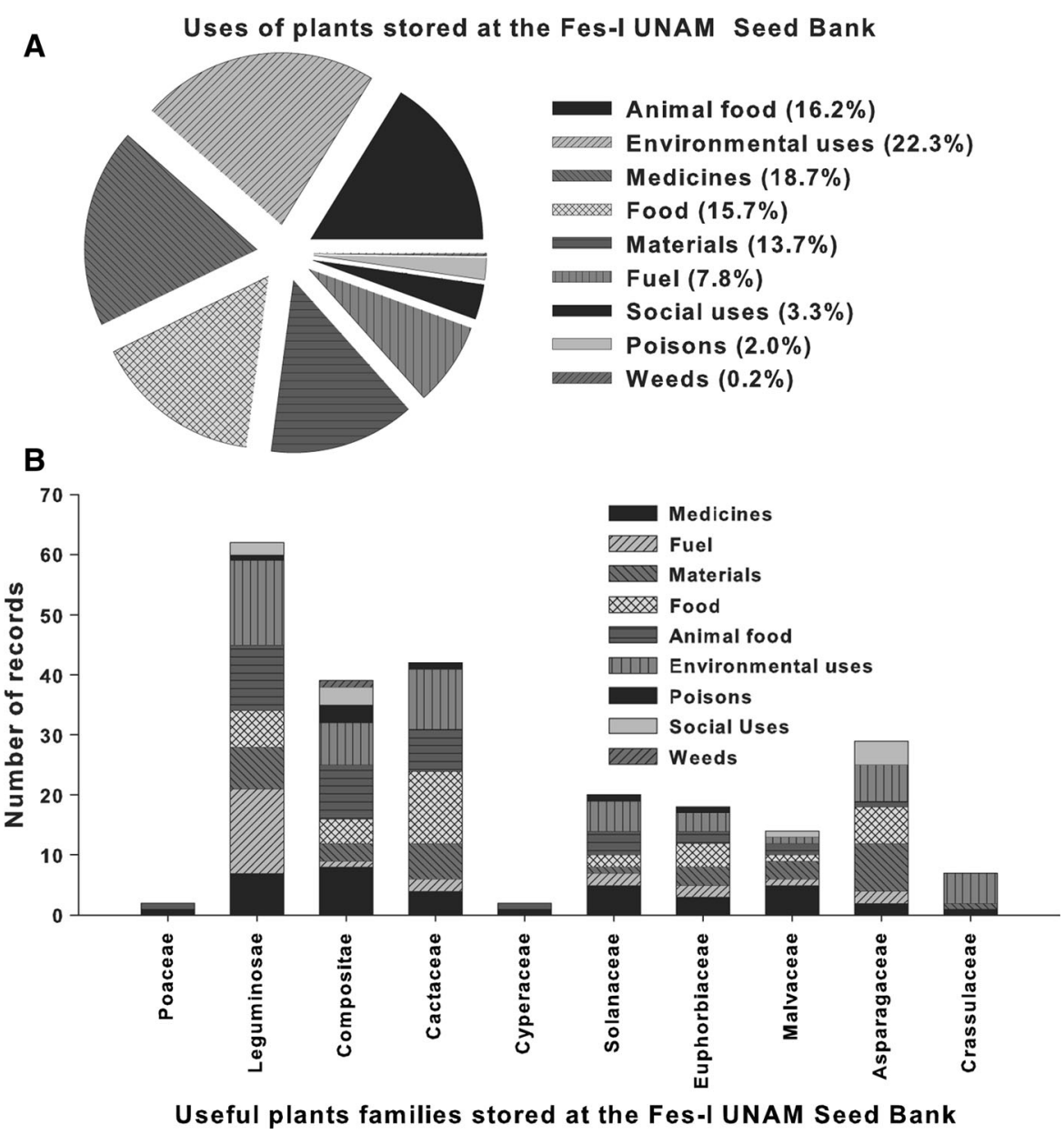

taxa) had a percentage of filled seeds $\leq 50 \%$ (Table 1). About $70 \%$ of the stored species had very few empty and infested seeds with $>80 \%$ of filled seeds.

Seed dormancy breaking and germination requirements

Seed germination experiments were carried out on seed lots of 77 species at the Fes-I UNAM Seed Bank. The results highlighted a poor seed viability for only 3 species, Heliocarpus terebinthinaceus (Malvaceae), Jatropha neopauciflora (Euphorbiaceae) and Actinocheita filicina (Anacardiaceae) showing values $<50 \%$ (Fig. 3). The majority of the seed lots (75\%) showed viability values higher than $90 \%$ (Fig. 3). About $51 \%$ of the investigated species showed Dormancy Index values lower than 0.4 (i.e. non dormant) with $27 \%$ being completely non dormant (DI $=0$; Appendix 2).
On the contrary, seeds of five species were completely dormant $(\mathrm{DI}=1)$ : Coursetia caribaea (Leguminosae), Passiflora foetida (Passifloraceae), Cardiospermum halicacabum (Sapindaceae), Melochia tomentosa (Malvaceae) and Bursera aptera (Burseraceae).

Seed germination experiments were carried out on 51 species at the MSB. Results and conditions applied are listed in Appendix 2. Nine taxa (corresponding to $18 \%$ ) were dormant (DI $>0.4$; Table 2), while the remaining $82 \%$ of the tested species had seed lots with DI values lower than 0.4 and therefore could be considered as non dormant, with $51 \%$ (26 species) being completely non dormant (DI $=0$; Appendix 2). Differences on DI values for the same species were due to the different applied germination conditions (see Appendix 2).

Seed germination experiments were carried out both at the RBG Kew's MSB and at the Fes-I UNAM Seed Bank for 35 taxa. The linear regression did not 
Table 1 Useful species for which a percentage of filled seeds $\leq 50 \%$ was detected by X-ray analysis at the RBG Kew's Millennium Seed Bank (MSB)

\begin{tabular}{lll}
\hline Family & Taxa & Filled seeds (\%) \\
\hline Amaranthaceae & Gomphrena serrata L. & 14 \\
Compositae & Gymnolaena oaxacana (Greenm.) Rydb. & 20 \\
Anacardiaceae & Amphipterygium adstringens (Schltdl.) Standl. & 27 \\
Burseraceae & Bursera submoniliformis Engl. & 30 \\
Bignoniaceae & Tecoma stans (L.) Juss. ex Kunth & 30 \\
Leguminosae & Prosopis laevigata (Willd.) M.C. Johnst. & 40 \\
Malvaceae & Heliocarpus terebinthinaceus (DC.) Hochr. & 40 \\
Burseraceae & Bursera morelensis Ramirez & 45 \\
Leguminosae & Acacia compacta Rose & 50 \\
Burseraceae & Bursera fagaroides (Kunth) Engl. & 50 \\
Verbenaceae & Lantana camara L. & 50 \\
\hline
\end{tabular}

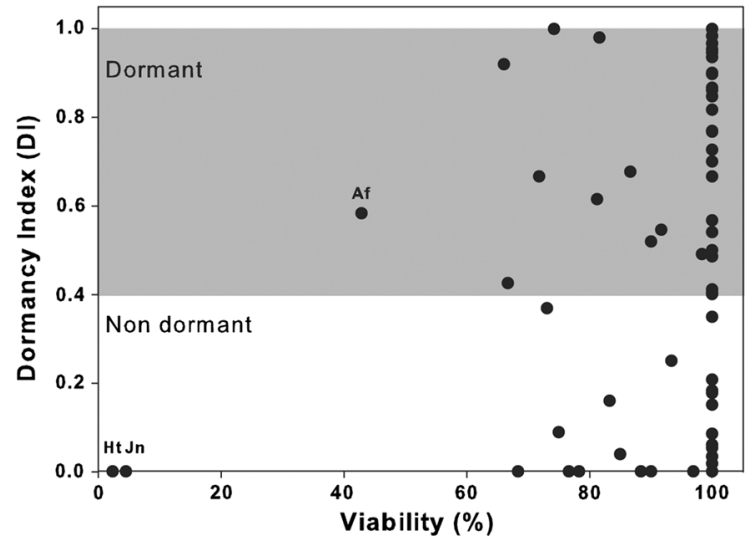

Fig. 3 Coplot indicating the common occurrence of seed viability and seed dormancy index (DI) for the 77 useful plants tested for seed germination at the Fes-I UNAM Seed Bank. The grey area highlights seed lots with DI $>0.4$ which are considered to be dormant (Offord et al. 2004). Ht: Heliocarpus terebinthinaceus, Jn: Jatropha neopauciflora, and Af: Actinocheita filicina

highlight any statistically significant correlation $(p=0.97 ; \mathrm{n}=35)$ between the DI values achieved for each species, mainly due to the different applied germination conditions (see Appendix 2). The taxa for which the dormant status (i.e., DI $>0.4$ ) detected at the RBG Kew's MSB was confirmed by the results achieved at the Fes-I UNAM are highlighted in bold in Table 2. The 16 taxa for which the non dormant satus (i.e., DI <0.4) detected at the RBG Kew's MSB was confirmed by the results achieved at the Fes-I UNAM are listed in Table 3.

\section{Discussion}

Conventional seed banking of useful plant species

Although the activities of the UPP focused in an area which corresponds to less than $1 \%$ of the whole Tehuacán-Cuicatlan Valley, ca. $12 \%$ of the whole flora of bankable useful plants (i.e. desiccation tolerant species; see Appendix 1) have been collected and stored at the Fes-I UNAM Seed Bank. This excludes the Fagaceae, one of the most important useful plant families in the Valley (Lira et al. 2009a), including the genus Quercus in particular whose species have been reported to have recalcitrant seeds (Hong et al. 1998; Xia et al. 2012) and for which alternative measures, such as cryopreservation of the embryonic axes, should be applied in order to guarantee their long term conservation (Gonzalez-Benito and Perez-Ruiz 1992). These results are of particular importance when the poor representation of underutilised species, including crop wild relatives, in ex situ gene banks' collections globally (Padulosi et al. 2002; Castañeda-Álvarez et al. 2016) is considered in conjunction with the potential loss of effectiveness of protected areas (i.e. in situ conservation) in preserving underutilised species under future climate change conditions (Lira et al. 2009b).

The most useful plant families with desiccation tolerant seeds are well represented in terms of number of useful species stored at the Fes-I UNAM Seed Bank, except for Poaceae and Cyperaceae. These two families are among the most demanded plants that are used as fodder (Lira et al. 2009a). However, their 
Table 2 Useful species for which seed dormancy issues were detected at the RBG Kew's Millennium Seed Bank (MSB) (DI > 0.4; Offord et al. 2004)

\begin{tabular}{lllc}
\hline Family & Taxon & MSB (DI) & Fes-I (DI) \\
\hline Burseraceae & Bursera submoniliformis Engl. & $\mathbf{0 . 8 0}$ & $\mathbf{0 . 8 4}$ \\
Bignoniaceae & Tecoma stans (L.) Juss. ex Kunth & 0.62 & 0.0 \\
Verbenaceae & Lippia graveolens Kunth & $\mathbf{0 . 6}$ & $\mathbf{0 . 4 9}$ \\
Euphorbiaceae & Jatropha neopauciflora Pax & 0.57 & 0.0 \\
Malvaceae & Ceiba aesculifolia (Kunth) Britten et Baker f. subsp. & 0.55 & 0.37 \\
Rhamnaceae & parvifolia (Rose) P.E. Gibbs et Semir & $\mathbf{0 . 5 5}$ \\
Rhamnaceae & Karwinskia mollis Schltdl. & 0.55 \\
Anacardiaceae & Ziziphus pedunculata (Brandegee) Standl. & $\mathbf{0 . 5}$ & $\mathbf{0 . 6 8}$ \\
Bignoniaceae & Actinocheita filicina (DC.) F.A. Barkley & 0.45 \\
\hline
\end{tabular}

When available, the DI values obtained for the same species at the Fes-I UNAM Seed Bank are also reported. The taxa for which the dormant status detected at the RBG Kew's MSB was confirmed by the experiments carried out at the Fes-I UNAM Seed Bank are shown in bold text. Differences on DI values for the same species were due to the different applied germination conditions

difficult taxonomic identification in the field as well as the unpredictability of their seed dispersal time, which in annual species living in semiarid environments is strongly related to rainfall patterns, affected the planning and implementation of seed collection for these species. The selection of target species for seed collections was also influenced by the preference of local rural communities for human food and multi-purpose species, such as the Cactaceae (Lira et al. 2009a), which are over-represented among the collections of the Fes-I Seed Bank. This positive bias on representativity may therefore be determined by a sort of "flag species" effect, in order to answer the needs of the communities involved in the UPP which aimed to support the improvement of their wellbeing (Ulian et al. 2016). It should also be highlighted that for conservation value, only 83 taxa of Cyperales (Cyperaceae plus Graminae/Poaceae) are listed in the IUCN Global Red List, with only one of them (Carex austromexicana Reznicek) reported as critically endangered (CR), whilst these figures increase to 596 taxa $(32 \mathrm{CR})$ for the Cactaceae (IUCN 2015).

It should also be considered that these figures refer to the UPP only, whereas a broader seed collecting and conservation programme focusing on plant conservation in the drylands has been active since 2002 in the same region through the MSB Partnership (see LeónLobos et al. 2012).
Seed longevity under conventional seed banking conditions

High viability was detected for the stored seed lots, reaching an average of $92 \%$, with the majority of them $(75 \%)$ showing values higher than $90 \%$. These data confirm the high quality of the banked seed lots and their potentiality for use in plant propagation activities. Godefroid et al. (2010), in a study on seed germination and capacity and viability of threatened wild species stored at the National Botanic Garden of Belgium Seed Bank, found that seed viability of the 250 tested species reached on average $79 \%$. However, while viability tests of this study were carried out at the beginning of the storage (after one month; Terry et al. 2003), the results of Godefroid et al. (2010) refers to seed lots stored up to 26 years. As reported by the same authors, some species may have declined in seed viability during storage because they are short lived. This has been experimentally confirmed by Probert et al. (2009), who showed that longevity is related to seed structure and the climate of the area from where they were collected. Species with endospermic seeds appear to be typically short lived, and seeds from species originating in cool, wet environments are likely to have shorter lifespans than those from warm, dry environments (Probert et al. 2009). Therefore, further studies with controlled ageing tests (Newton et al. 2014) should be carried out, considering that all 
Table 3 Taxa for which the non dormant status detected at the Millennium Seed Bank (MSB) (DI < 0.4; Offord et al. 2004) was confirmed by the experiments carried out at the Fes-I UNAM Seed Bank

\begin{tabular}{|c|c|c|c|c|}
\hline Family & Taxon & $\begin{array}{l}\text { MSB } \\
\text { (DI) }\end{array}$ & $\begin{array}{l}\text { Fes-I } \\
\text { (DI) }\end{array}$ & Use \\
\hline Amaranthaceae & Chenopodium murale $\mathrm{L}$. & 0.3 & 0.2 & Environmental use \\
\hline Anacardiaceae & Amphipterygium adstringens (Schltdl.) Standl. ${ }^{a}$ & 0.3 & $\mathbf{0 . 0}$ & Medicines, Materials \\
\hline Apocynaceae & Matelea trachyantha (Greenm.) W.D. Stevens & 0.0 & 0.1 & Food, Environmental use \\
\hline Asparagaceae & Agave macroacantha Zucc. & 0.4 & 0.2 & Food, Environmental use \\
\hline Bromeliaceae & Hechtia podantha Mez. & 0.0 & 0.0 & Environmental use \\
\hline Cactaceae & $\begin{array}{l}\text { Escontria chiotilla (A.A. Weber ex K. Schum.) } \\
\text { Rose }\end{array}$ & 0.1 & $\mathbf{0 . 0}$ & $\begin{array}{l}\text { Food, Animal food, Materials, } \\
\text { Fuels, Environmental use }\end{array}$ \\
\hline Convolvulaceae & Ipomoea pauciflora $\mathrm{M}$. Martens et Galeotti & 0.0 & 0.0 & Environmental use \\
\hline Euphorbiaceae & Manihot pauciflora Brandegee & 0.1 & 0.4 & Materials \\
\hline Fouqueriaceae & Fouquieria formosa Kunth & 0.0 & 0.1 & Environmental use \\
\hline Leguminosae & Acacia cochliacantha Willd. & 0.0 & 0.0 & Social uses \\
\hline Leguminosae & Acacia farnesiana (L.) Willd. & 0.0 & 0.0 & $\begin{array}{l}\text { Fuels, Animal food, Medicines, } \\
\text { Poisons }\end{array}$ \\
\hline Leguminosae & Caesalpinia melanadenia (Rose) Standl. & 0.3 & 0.0 & $\begin{array}{l}\text { Animal food, Medicines, Materials, } \\
\text { Fuels }\end{array}$ \\
\hline Leguminosae & Coursetia glandulosa A. Gray & 0.0 & 0.1 & Fuels, Animal food \\
\hline Leguminosae & Indigofera conzattii Rose & 0.0 & 0.0 & Environmental use \\
\hline Leguminosae & Mimosa luisana Brandegee & 0.0 & 0.0 & $\begin{array}{l}\text { Fuels, Animal food, Environmental } \\
\text { use }\end{array}$ \\
\hline Leguminosae & Parkinsonia praecox (Ruiz et Pav.) Hawkins & $\mathbf{0 . 0}$ & $\mathbf{0 . 0}$ & Food, Environmental use \\
\hline Leguminosae & Prosopis laevigata (Willd.) M.C. Johnst. ${ }^{\mathrm{a}}$ & 0.0 & 0.0 & Animal food, Medicines, Materials \\
\hline Leguminosae & Senna wislizeni (A. Gray) H.S. Irwin et Barneby & 0.0 & 0.0 & Food \\
\hline
\end{tabular}

Differences on DI values for the same species were due to the different applied germination conditions. Their uses according to the first level of "Economic Botany data collection standards" (Cook 1995, modified) are also reported. Species for which plant propagation activities were already carried out on the framwork of the UPP are in bold text

${ }^{a}$ Species for which a poor seed quality was detected (see Table 1)

the bankable most useful plant families of the Valley, except Leguminosae, are constituted by species with endospermic seeds (Fig. 4).

Difficult seed collections

Alternative conservation measures should be considered for species producing few filled seeds (see those identified in this study in Table 1), because seed collection efforts made in the field did not produce a seed lot representative of the genetic diversity of the original population (Fig. 4). This was the case for Gomprena serrata (Amaranthaceae) and Gymnolaena oaxacana (Compositae), whose percentage of filled seeds was less than $20 \%$. Compositae have been listed among the families producing high percentages of empty seeds (ENSCONET 2009) and for Mexican species of this family, as well as for species of other families, this phenomenon can be related to and emphasized by the lack of water availability during seed development. When seed quality is very poor, complementary ex situ conservation measures, such as in vitro propagation, should be applied (Pence 2013).

For the other species with low seed quality identified in this study (see Table 1), conventional seed banking can still be suggested (Fig. 4), although seed collections in the field should be carried out with extra care (Way 2003). In particular, production of parthenocarpic empty fruits has been reported for Bursera morelensis (Ramos-Ordoñez et al. 2008), one of the most useful species of the Valley (i.e. used for fodder, firewood, wood and construction material, living fences, resins/latex, soil control, colorant; Lira et al. 2009a) and other Bursera species (RamosOrdoñez et al. 2012). Seeded and parthenocarpic fruits can be separated in the field at maturity by the 

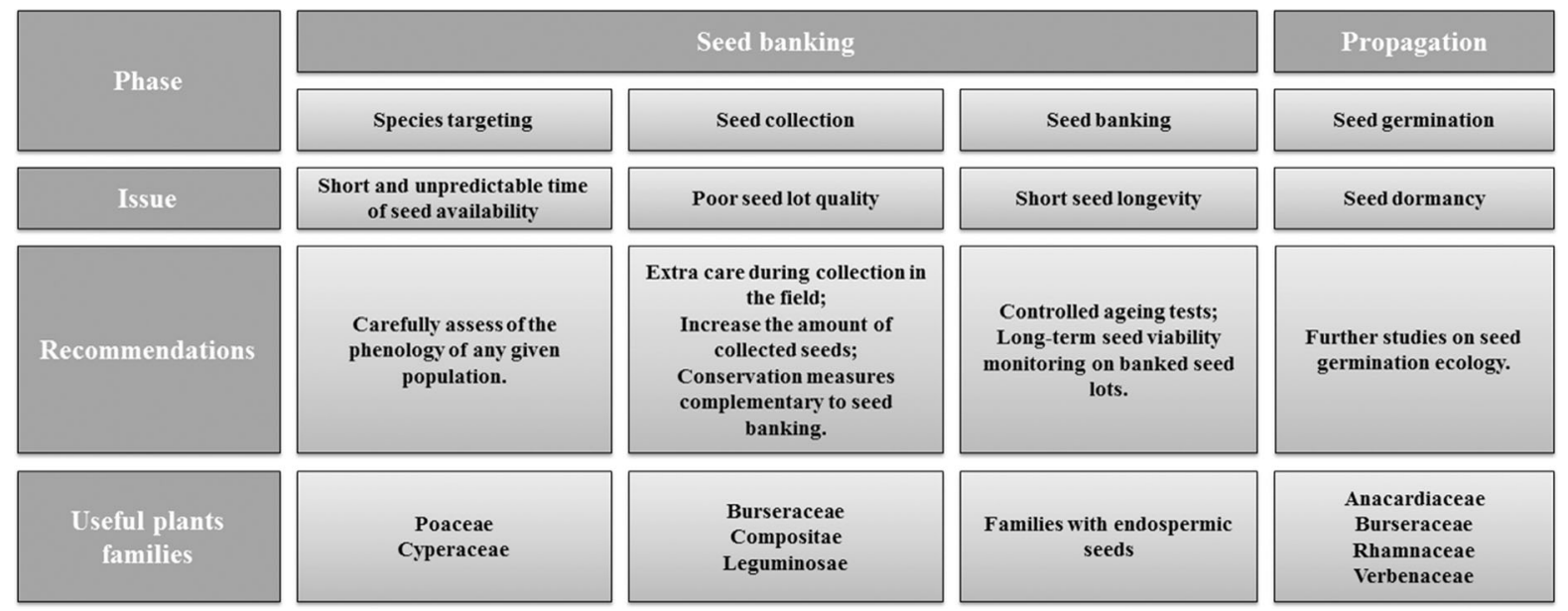

Fig. 4 Key issues identified for the main phases of seed conservation and propagation of useful plants in Mexico. For each issues, recommendations and families affected are also summarized

presence of dehiscence, which is complete in seeded and partial in the parthenocarpic ones (RamosOrdoñez et al. 2008). Damaged seeds in a seedlot can occur due to attack by insects or microbial pathogens at different stages in the seed life-cycle (Way 2003). Leguminosae, in particular Acacia and Mimosa species, are among the taxa for which damage level exceeded the $50 \%$ of banked accessions (Way 2003) as assessed in this study for A. compacta and Prosopis laevigata. It is very difficult to distinguish in the field between viable and infested seeds on Leguminosae and the loss of viable seeds should be compensated by extra seed collecting (Way 2003).

The germination and subsequent cut tests carried out on the stored seed lots identified three species with low seed viability $(<50 \%)$, although seeds appeared filled by X-ray analysis. These species were Actinocheita filicina (Anacardiaceae), Jatropha neopauciflora (Euphorbiaceae) and Heliocarpus terebinthinaceaus (Malvaceae). All these species can be found in narrow populations with few individuals and therefore, the low seed viability detected could be related to inbreeding (Ågren 1996; Fischer and Matthies 1998) or pollination related problems (Fischer and Matthies 1998; Jacquemyn et al. 2002), although this should be confirmed by further studies. In addition, seeds of $J$. neopauciflora were collected before the right time of maturation because ripe seeds are available in the field only for a short period, due to their slow development and those of $H$. terebinthinaceaus are affected by high percentages of predation by insects on the plant.
Seed dormancy as an issue for plant propagation

The different seed processing and germination protocols used in the two institutions in some cases led to different germination results, highlighting the importance of published information on seed germination of wild native species (Godefroid et al. 2010; Hay and Probert 2013; Baskin and Baskin 2014). It should also be taken into account that due to facility constraints at the Fes-I UNAM Seed Bank, only one germination condition could be tested. In this study it was possible to confirm the presence of seed dormancy for four species (see Table 2): Actinocheita filicina (Anacardiaceae), Bursera submoniliformis (Burseraceae), Karwinskia mollis (Rhamnaceae) and Lippia graveolens (Verbenaceae), with limited information on seed germination being available in the literature for seed germination of these species (Fig. 4).

Fruits of Bursera sp. are dispersed through endozoochory which means that the seeds are protected against physical and chemical damage by hard layers (Ramos-Ordoñez et al. 2012). This woody endocarp could lead to physical (PY) or physiological (PD) seed dormancy depending on its permeability to water, whether it allows seed imbibition or not (RamosOrdoñez et al. 2012). Seeds of many Burseraceae are reported to have PD or to be non dormant (Baskin and Baskin 2014). Limited information is available in the literature on seed germination requirements of Lippia species (but see Galíndez et al. 2016)and most of the study took a common garden approach, with seeds 
sown in the soil and incubated in nursery conditions (e.g., Mata-González and Meléndez-González 2005; Alui Konan et al. 2013).

For all these four species, further studies using freshly collected seeds, with a factorial experimental approach under laboratory controlled conditions, should be carried out in order to identify the best treatments and incubation conditions for seed dormancy breaking and germination (Baskin et al. 2006). Alternatively, as dormancy level is likely to change during cold storage, and the conditions required for germination become less specific (Probert 2000), the effect of storage time on seed germination should be considered and assessed, if using stored seed lots instead of freshly collected seeds, in seed dormancy studies (i.e. Vandelook et al. 2012; Mattana et al. 2014).

Useful species whose plant propagation by seed is not affected by dormancy

A total of 18 species with a non dormant status were identified (see Table 3). Among them, Acacia farnesiana, Amphipteryngium adstringens and Fouquieria formosa are reported by Lira et al. (2009a) as being most used by the local communities of the Valley. However, A. adstringens was identified in this study as one of the species with a low production of viable seeds and therefore the propagation by seed of this species is constrained by seed availability.

Interestingly, the majority of these species are woody or tree species, suggesting that they could be used to support reforestation programmes with useful indigenous species, as aimed for by the UPP (Ulian et al. 2016) and confirmed by the successful propagation of five of these species through the project (see Table 3). In addition, half of these species are Leguminosae which have been reported to act as "nurse plants" (e.g. Caesalipinia melanadenia, Senna wislizeni, Parkinsonia praecox, Prosopis laevigata; Valiente-Banuet et al. 1991; Morello-Calles and Casas 2010) and "resource islands" (e.g. Mimosa luisana; Camargo-Ricalde et al. 2002), for endangered cactus species of the Tehuacán-Cuicatlan Valley, such as the globose Mammillaria carnea, M. haagena and Corypantha pallida (Mandujano et al. 2002), Myrtillocactus geometrizans, Neobuxbaumia tetetzo and Opuntia pilifera (Garcia-Chávez et al. 2014) and Stenocereus stellatus (Álvarez-Espino et al. 2014), adding ecological and conservation values to their use in restoration programmes. However, it should be taken into account that seed germination is only one of the steps in the plant life cycle and other issues could be detected in seedling establishment and survival.

Seed banking and germination studies as a support to the preservation of the traditional knowledge

Knowledge on the use of plants is disappearing faster than the plants themselves (Alves and Rosa 2007). Therefore, conservation of useful plants should not be limited to the preservation of their genetic resources, but it should include the cataloguing and preservation for future generations of their traditional uses. Through the UPP, information on plant and plant products uses associated to the species stored in the seed banks have been gathered and managed through a dedicated database (Ulian et al. 2016). The uses of the ethnoflora of the Tehuacán-Cuicatlan Valley have been well investigated and documented in the past (e.g. Casas et al. 2001; Lira et al. 2009a). All the main categories of uses documented for the Valley (Lira et al. 2009a) are represented in the seed collections carried out through the UPP. Therefore, seed banking of wild useful species contributed to the preservation of the traditional knowledge of these rural communities by: (1) ensuring a back up of the genetic resources of wild useful plants; (2) providing information on their germination protocols; and (3) documenting and cataloguing the associated traditional knowledge on their uses, which represents an additional challenge in respect to the conventional ex situ conservation of either wild species or crop varieties.

\section{Conclusions}

The conservation in seed banks carried out through the UPP, contributed to delivering the GSPC Target 9 for the conservation of "genetic diversity of crops including their wild relatives and other socio-economically valuable plant species, while respecting, preserving and maintaining associated indigenous and local knowledge" (www.cbd.int/gspc) and Aichi Biodiversity Target 18 for the respect of "the traditional knowledge, innovations and practices of indigenous and local communities relevant for the conservation and sustainable use of biodiversity, and their customary use of biological resources" (http:// www.cbd.int/sp/targets) in Mexico. In addition, these 
results contribute to the achievement of the Target 2.5 of the United Nations' Sustainable Development Goals: "By 2020, maintain the genetic diversity of seeds, cultivated plants and farmed and domesticated animals and their related wild species, including through soundly managed and diversified seed and plant banks at the national, regional and international levels, and promote access to and fair and equitable sharing of benefits arising from the utilization of genetic resources and associated traditional knowledge, as internationally agreed" (https:// sustainabledevelopment.un.org/sdgs). Moreover, the stored species may represent sources of new genetic diversity and, as for the crop wild relatives, potentially be available for plant breeding experiments, contributing a wide range of beneficial agronomic and nutritional traits (Castañeda-Álvarez et al. 2016).

The germination experiments carried out for the stored species allowed the identification of: (1) species for which more in depth studies on seed dormancy and germination are needed before considering their propagation by seed at a large scale; (2) species whose germination protocols and seed lot availability may already enhance their sustainable use through plant propagation by seed.

This study also confirmed that conventional seed banking represents an effective technique for ex situ conservation of useful wild plant species in Mexico and may complement their in situ conservation as well as the sustainable management of small scale agriculture (Blanckaert et al. 2007) and traditional homegardens (Blanckaert et al. 2004) in the preservation of plant diversity of the Biosphere Reserve of the Tehuacán-Cuicatlán Valley.

Acknowledgments This work has been funded by MGU, a philanthropist based in Spain, as part of "The Project MGU-the Useful Plants Project", managed by the Royal Botanic Gardens, Kew. The authors acknowledge the support of the local communities involved in the project and their authorities. Kenwin Liu (RBG Kew) helped with the analysis on the seed desiccation tolerance of the species listed in the Seed Information Database, SID. They also acknowledge the help of Hector Cervantes and Armando Ponce and the field technician Martin Lopez Carrera for seed collecting and all the staff and students of the Fes-I UNAM and MSB for seed processing and testing. Oswaldo Tellez (UNAM) and Gabriele Bradamante (RBG Kew) helped with data.

\section{Compliance with ethical standards}

Conflict of interest The authors declare that they have not conflict of interest.

Open Access This article is distributed under the terms of the Creative Commons Attribution 4.0 International License (http:// creativecommons.org/licenses/by/4.0/), which permits unrestricted use, distribution, and reproduction in any medium, provided you give appropriate credit to the original author(s) and the source, provide a link to the Creative Commons license, and indicate if changes were made.

\section{Appendix 1: The inventory of bankable useful plants of the Tehuacán-Cuicatlan Valley (from Lira et al. 2009a, modified)}

\begin{tabular}{|c|c|c|c|c|c|}
\hline Family & Genus & Specific epithet & Species authors & $\begin{array}{l}\text { Infraspecific } \\
\text { rank and epithet }\end{array}$ & $\begin{array}{l}\text { Infraspecific } \\
\text { taxon Authors }\end{array}$ \\
\hline Acanthaceae & Anisacanthus & gonzalezii & Greenm. & & \\
\hline Acanthaceae & Carlowrightia & neesiana & $\begin{array}{l}\text { (Schauer ex Nees) T.F. } \\
\text { Daniel }\end{array}$ & & \\
\hline Acanthaceae & Carlowrightia & pringlei & B.L. Rob. et Greenm. & & \\
\hline Acanthaceae & Elytraria & imbricata & (Vahl) Pers. & & \\
\hline Acanthaceae & Holographis & velutifolia & (House) T.F. Daniel & & \\
\hline Acanthaceae & Justicia & brandegeeana & Wassh. et L.B. Sm. & & \\
\hline Acanthaceae & Justicia & candicans & (Nees) L.D. Benson & & \\
\hline Acanthaceae & Justicia & gonzalezii & $\begin{array}{l}\text { (Greenm.) Henrickson et } \\
\text { Hiriart }\end{array}$ & & \\
\hline Acanthaceae & Justicia & spicigera & Schltdl. & & \\
\hline Acanthaceae & Justicia & ramosa & (Oerst.) V.A.W. Graham & & \\
\hline Acanthaceae & Ruellia & hirsutoglandulosa & (Oerst.) Hemsl. & & \\
\hline Acanthaceae & Ruellia & lactea & Cav. & & \\
\hline
\end{tabular}




\begin{tabular}{|c|c|c|c|c|c|}
\hline Family & Genus & Specific epithet & Species authors & $\begin{array}{l}\text { Infraspecific } \\
\text { rank and epithet }\end{array}$ & $\begin{array}{l}\text { Infraspecific } \\
\text { taxon Authors }\end{array}$ \\
\hline Acanthaceae & Tetramerium & nervosum & Nees & & \\
\hline Acanthaceae & Thunbergia & alata & Bojer ex Sims & & \\
\hline Aizoaceae & Mesembryanthemum & cordifolium & L.f. & & \\
\hline Alstroemeriaceae & Bomarea & edulis & (Tussac) Herb. & & \\
\hline Alstroemeriaceae & Bomarea & hirtella & (Kunth) Herb. & & \\
\hline Amaranthaceae & Alternanthera & obovata & $\begin{array}{l}\text { (M. Martens et Galeotti) } \\
\text { Millsp. }\end{array}$ & & \\
\hline Amaranthaceae & Alternanthera & pungens & Kunth & & \\
\hline Amaranthaceae & Amaranthus & hybridus & L. & & \\
\hline Amaranthaceae & Amaranthus & hypochondriacus & L. & & \\
\hline Amaranthaceae & Atriplex & pueblensis & Standl. & & \\
\hline Amaranthaceae & Beta & vulgaris & $\mathrm{L}$ & & \\
\hline Amaranthaceae & Chamissoa & altissima & (Jacq.) Kunth & & \\
\hline Amaranthaceae & Chenopodium & ambrosioides & L. & & \\
\hline Amaranthaceae & Chenopodium & berlandieri & Moq. & & \\
\hline Amaranthaceae & Chenopodium & incisum & Poir. & & \\
\hline Amaranthaceae & Chenopodium & murale & L. & & \\
\hline Amaranthaceae & Gomphrena & serrata & L. & & \\
\hline Amaranthaceae & Iresine & calea & (Ibantz) Standl. & & \\
\hline Amaranthaceae & Iresine & discolor & Greenm. & & \\
\hline Amaranthaceae & Iresine & pringlei & S. Watson & & \\
\hline Amaranthaceae & Iresine & schaffneri & S. Watson & & \\
\hline Amaryllidaceae & Allium & сера & L. & & \\
\hline Amaryllidaceae & Allium & glandulosum & Link et Otto & & \\
\hline Amaryllidaceae & Allium & sativum & L. & & \\
\hline Amaryllidaceae & Allium & longifolium & (Kunth) Spreng. & & \\
\hline Amaryllidaceae & Hymenocallis & harrisiana & Herb. & & \\
\hline Anacardiaceae & Actinocheita & filicina & (DC.) F.A. Barkley & & \\
\hline Anacardiaceae & Amphipterygium & adstringens & (Schltdl.) Standl. & & \\
\hline Anacardiaceae & Cyrtocarpa & procera & Kunth & & \\
\hline Anacardiaceae & Pseudosmodingium & multifolium & Rose & & \\
\hline Anacardiaceae & Rhus & chondroloma & Standl. & & \\
\hline Anacardiaceae & Rhus & standleyi & F.A. Barkley & & \\
\hline Anacardiaceae & Rhus & virens & Lindh. ex A. Gray & & \\
\hline Anacardiaceae & Schinus & molle & L. & & \\
\hline Anacardiaceae & Spondias & mombin & L. & & \\
\hline Annonaceae & Annona & cherimola & Mill. & & \\
\hline Annonaceae & Annona & muricata & L. & & \\
\hline Annonaceae & Annona & reticulata & $\mathrm{L}$. & & \\
\hline Apiaceae & Coriandrum & sativum & L. & & \\
\hline Apiaceae & Eryngium & bonplandii & F. Delaroche & & \\
\hline Apiaceae & Eryngium & pectinatum & C. Presl ex DC. & & \\
\hline Apiaceae & Foeniculum & vulgare & Mill. & & \\
\hline
\end{tabular}




\begin{tabular}{|c|c|c|c|c|c|}
\hline Family & Genus & Specific epithet & Species authors & $\begin{array}{l}\text { Infraspecific } \\
\text { rank and epithet }\end{array}$ & $\begin{array}{l}\text { Infraspecific } \\
\text { taxon Authors }\end{array}$ \\
\hline Apiaceae & Petroselinum & crispum & (Mill.) Fuss & & \\
\hline Apocynaceae & Asclepias & curassavica & L. & & \\
\hline Apocynaceae & Asclepias & linaria & Cav. & & \\
\hline Apocynaceae & Cascabela & ovata & (Cav.) Lippold & & \\
\hline Apocynaceae & Cascabela & thevetia & (L.) Lippold & & \\
\hline Apocynaceae & Cascabela & thevetioides & (Kunth) Lippold & & \\
\hline Apocynaceae & Catharanthus & roseus & (L.) G. Don & & \\
\hline Apocynaceae & Cryptostegia & madagascariensis & Bojer ex Decne. & & \\
\hline Apocynaceae & Funastrum & pannosum & (Hemsl.) Schltr. & & \\
\hline Apocynaceae & Gonolobus & pectinatus & Brandegee & & \\
\hline Apocynaceae & Marsdenia & parvifolia & Brandegee & & \\
\hline Apocynaceae & Matelea & crenata & (Vail) Woodson & & \\
\hline Apocynaceae & Matelea & trachyantha & (Greenm.) W.D. Stevens & & \\
\hline Apocynaceae & Nerium & oleander & L. & & \\
\hline Apocynaceae & Orbea & variegata & (L.) Haw. & & \\
\hline Apocynaceae & Plumeria & rubra & L. & & \\
\hline Apocynaceae & Rauvolfia & tetraphylla & L. & & \\
\hline Apocynaceae & Sarcostemma & elegans & Decne. & & \\
\hline Apocynaceae & Vallesia & glabra & (Cav.) Link & & \\
\hline Araceae & Alocasia & macrorrhizos & (L.) G. Don & & \\
\hline Araceae & Anthurium & andraeanum & Linden ex André & & \\
\hline Araceae & Anthurium & crassinervium & (Jacq.) Schott & & \\
\hline Araceae & Caladium & bicolor & (Aiton) Vent. & & \\
\hline Araceae & Dieffenbachia & picta & Schott & & \\
\hline Araceae & Dieffenbachia & seguine & (Jacq.) Schott & & \\
\hline Araceae & Epipremnит & aureum & $\begin{array}{l}\text { (Linden et André) G.S. } \\
\text { Bunting }\end{array}$ & & \\
\hline Araceae & Monstera & adansonii & Schott & & \\
\hline Araceae & Monstera & deliciosa & Liebm. & & \\
\hline Araceae & Philodendron & pinnatifidum & (Jacq.) Schott & & \\
\hline Araceae & Xanthosoma & robustum & Schott & & \\
\hline Araceae & Zantedeschia & aethiopica & (L.) Spreng. & & \\
\hline Araliaceae & Aralia & humilis & Cav. & & \\
\hline Araliaceae & Hedera & helix & L. & & \\
\hline Araliaceae & Polyscias & balfouriana & L.H. Bailey & & \\
\hline Arecaceae & Brahea & dulcis & (Kunth) Mart. & & \\
\hline Arecaceae & Brahea & calcarea & Liebm. & & \\
\hline Arecaceae & Phoenix & dactylifera & L. & & \\
\hline Asparagaceae & Agave & americana & L. & & \\
\hline Asparagaceae & Agave & atrovirens & Karw. ex Salm-Dyck & & \\
\hline Asparagaceae & Agave & karwinskii & Zucc. & & \\
\hline Asparagaceae & Agave & kerchovei & Lem. & & \\
\hline Asparagaceae & Agave & macroacantha & Zucc. & & \\
\hline Asparagaceae & Agave & marmorata & Roezl & & \\
\hline
\end{tabular}




\begin{tabular}{|c|c|c|c|c|c|}
\hline Family & Genus & Specific epithet & Species authors & $\begin{array}{l}\text { Infraspecific } \\
\text { rank and epithet }\end{array}$ & $\begin{array}{l}\text { Infraspecific } \\
\text { taxon Authors }\end{array}$ \\
\hline Asparagaceae & Agave & peacockii & Croucher & & \\
\hline Asparagaceae & Agave & potatorum & Zucc. & & \\
\hline Asparagaceae & Agave & salmiana & Otto ex Salm-Dyck & & \\
\hline Asparagaceae & Agave & sisalana & Perrine & & \\
\hline Asparagaceae & Agave & stricta & Salm-Dyck & & \\
\hline Asparagaceae & Agave & triangularis & Jacobi & & \\
\hline Asparagaceae & Beaucarnea & gracilis & Lem. & & \\
\hline Asparagaceae & Chlorophytum & comosum & (Thunb.) Jacques & & \\
\hline Asparagaceae & Cordyline & stricta & (Sims) Endl. & & \\
\hline Asparagaceae & Dasylirion & serratifolium & $\begin{array}{l}\text { (Karw. ex Schult. et Schult.f.) } \\
\text { Zucc. }\end{array}$ & & \\
\hline Asparagaceae & Dracaena & braunii & Engl. & & \\
\hline Asparagaceae & Echeandia & conzattii & Cruden & & \\
\hline Asparagaceae & Furcraea & tuberosa & (Mill.) Aiton & & \\
\hline Asparagaceae & Nolina & longifolia & $\begin{array}{l}\text { (Karw. ex Schult. et Schult.f.) } \\
\text { Hemsl. }\end{array}$ & & \\
\hline Asparagaceae & Polyanthes & tuberosa & L. & & \\
\hline Asparagaceae & Sansevieria & trifasciata & Prain & & \\
\hline Asparagaceae & Sansevieria & zeylanica & Roxb. & & \\
\hline Asparagaceae & Yисса & periculosa & Baker & & \\
\hline Balsaminaceae & Impatiens & balsamina & L. & & \\
\hline Begoniaceae & Begonia & gracilis & Kunth & & \\
\hline Betulaceae & Alnus & acuminata & Kunth & & \\
\hline Betulaceae & Alnus & jorullensis & Kunth & & \\
\hline Bignoniaceae & Astianthus & viminalis & (Kunth) Baill. & & \\
\hline Bignoniaceae & Jacaranda & mimosifolia & D. Don & & \\
\hline Bignoniaceae & Parmentiera & aculeata & (Kunth) Seem. & & \\
\hline Bignoniaceae & Podranea & ricasoliana & (Tanfani) Sprague & & \\
\hline Bignoniaceae & Tecoma & stans & (L.) Juss. ex Kunth & & \\
\hline Boraginaceae & Antiphytum & heliotropioides & A.DC. & & \\
\hline Boraginaceae & Antiphytum & paniculatum & I.M. Johnst. & & \\
\hline Boraginaceae & Borago & officinalis & L. & & \\
\hline Boraginaceae & Cordia & curassavica & (Jacq.) Roem. et Schult. & & \\
\hline Boraginaceae & Cordia & oaxacana & A. DC. & & \\
\hline Boraginaceae & Cordia & spinescens & L. & & \\
\hline Boraginaceae & Cordia & stellata & Greenm. & & \\
\hline Boraginaceae & Cordia & alba & (Jacq.) Roem. et Schult. & & \\
\hline Boraginaceae & Ehretia & latifolia & Loisel. ex A. DC. & & \\
\hline Boraginaceae & Heliotropium & angiospermum & Murray & & \\
\hline Boraginaceae & Heliotropium & curassavicum & L. & & \\
\hline Boraginaceae & Heliotropium & procumbens & Mill. & & \\
\hline Boraginaceae & Nama & dichotoma & (Ruiz et Pav.) Choisy & & \\
\hline Boraginaceae & Tournefortia & mutabilis & Vent. & & \\
\hline Boraginaceae & Tournefortia & volubilis & L. & & \\
\hline
\end{tabular}




\begin{tabular}{|c|c|c|c|c|c|}
\hline Family & Genus & Specific epithet & Species authors & $\begin{array}{l}\text { Infraspecific } \\
\text { rank and epithet }\end{array}$ & $\begin{array}{l}\text { Infraspecific } \\
\text { taxon Authors }\end{array}$ \\
\hline Boraginaceae & Wigandia & urens & (Ruiz et Pav.) Kunth & & \\
\hline Brassicaceae & Brassica & rapa & L. & & \\
\hline Brassicaceae & Brassica & oleracea & L. & & \\
\hline Brassicaceae & Capsella & bursa-pastoris & (L.) Medik. & & \\
\hline Brassicaceae & Descurainia & virletii & (E. Fourn.) O.E. Schulz & & \\
\hline Brassicaceae & Eruca & sativa & Mill. & & \\
\hline Brassicaceae & Lepidium & virginicum & L. & & \\
\hline Brassicaceae & Matthiola & incana & (L.) R. Br. & & \\
\hline Brassicaceae & Nasturtium & officinale & R. Br. & & \\
\hline Brassicaceae & Raphanus & sativus & L. & & \\
\hline Bromeliaceae & Ananas & comosus & (L.) Merr. & & \\
\hline Bromeliaceae & Catopsis & compacta & Mez & & \\
\hline Bromeliaceae & Hechtia & bracteata & Mez & & \\
\hline Bromeliaceae & Hechtia & confusa & L.B. Sm. & & \\
\hline Bromeliaceae & Hechtia & conzattiana & L.B. Sm. & & \\
\hline Bromeliaceae & Hechtia & fragilis & Burt-Utley et Utley & & \\
\hline Bromeliaceae & Hechtia & galeottii & Mez & & \\
\hline Bromeliaceae & Hechtia & glomerata & Zucc. & & \\
\hline Bromeliaceae & Hechtia & lyman-smithii & Burt-Utley et Utley & & \\
\hline Bromeliaceae & Hechtia & podantha & Mez & & \\
\hline Bromeliaceae & Hechtia & pringlei & B.L. Rob. et Greenm. & & \\
\hline Bromeliaceae & Hechtia & roseana & L.B. Sm. & & \\
\hline Bromeliaceae & Hechtia & sphaeroblasta & B.L. Rob. & & \\
\hline Bromeliaceae & Hechtia & liebmannii & Mez & & \\
\hline Bromeliaceae & Tillandsia & concolor & L.B. Sm. & & \\
\hline Bromeliaceae & Tillandsia & dasyliriifolia & Baker & & \\
\hline Bromeliaceae & Tillandsia & grandis & Schltdl. & & \\
\hline Bromeliaceae & Tillandsia & plumosa & Baker & & \\
\hline Bromeliaceae & Tillandsia & pueblensis & L.B. Sm. & & \\
\hline Bromeliaceae & Tillandsia & recurvata & (Gaudich.) Baker & & \\
\hline Bromeliaceae & Tillandsia & usneoides & (L.) L. & & \\
\hline Burseraceae & Bursera & aptera & Ramírez & & \\
\hline Burseraceae & Bursera & arida & (Rose) Standl. & & \\
\hline Burseraceae & Bursera & biflora & (Rose) Standl. & & \\
\hline Burseraceae & Bursera & bipinnata & (Moc. et Sessé ex DC.) Engl. & & \\
\hline Burseraceae & Bursera & cinerea & Engl. & & \\
\hline Burseraceae & Bursera & copallifera & $\begin{array}{l}\text { (Sessé et Moc. ex DC.) } \\
\text { Bullock }\end{array}$ & & \\
\hline Burseraceae & Bursera & diversifolia & Rose & & \\
\hline Burseraceae & Bursera & fagaroides & (Kunth) Engl. & & \\
\hline Burseraceae & Bursera & galeottiana & Engl. & & \\
\hline Burseraceae & Bursera & glabrifolia & (Kunth) Engl. & & \\
\hline Burseraceae & Bursera & laxiflora & S. Watson & & \\
\hline Burseraceae & Bursera & mirandae & C.A. Toledo & & \\
\hline
\end{tabular}




\begin{tabular}{|c|c|c|c|c|c|}
\hline Family & Genus & Specific epithet & Species authors & $\begin{array}{l}\text { Infraspecific } \\
\text { rank and epithet }\end{array}$ & $\begin{array}{l}\text { Infraspecific } \\
\text { taxon Authors }\end{array}$ \\
\hline Burseraceae & Bursera & morelensis & Ramírez & & \\
\hline Burseraceae & Bursera & schlechtendalii & Engl. & & \\
\hline Burseraceae & Bursera & simaruba & (L.) Sarg. & & \\
\hline Burseraceae & Bursera & submoniliformis & Engl. & & \\
\hline Burseraceae & Bursera & linanoe & $\begin{array}{l}\text { (La Llave) Rzed., Calderón et } \\
\text { Medina }\end{array}$ & & \\
\hline Cactaceae & Acanthocereus & subinermis & Britton et Rose & & \\
\hline Cactaceae & Cephalocereus & columna-trajani & (Karw. ex Pfeiff.) K. Schum. & & \\
\hline Cactaceae & Coryphantha & pallida & Britton et Rose & & \\
\hline Cactaceae & Coryphantha & pycnacantha & (Mart.) Lem. & & \\
\hline Cactaceae & Disocactus & flagelliformis & (L.) Barthlott & & \\
\hline Cactaceae & Echinocactus & platyacanthus & Link et Otto & & \\
\hline Cactaceae & Echinocereus & pulchellus & (Mart.) K. Schum. & & \\
\hline Cactaceae & Escontria & chiotilla & $\begin{array}{l}\text { (A.A. Weber ex K. Schum.) } \\
\text { Rose }\end{array}$ & & \\
\hline Cactaceae & Ferocactus & flavovirens & (Scheidw.) Britton et Rose & & \\
\hline Cactaceae & Ferocactus & haematacanthus & $\begin{array}{c}\text { (Monv. ex Salm-Dyck) Bravo } \\
\text { ex Backeb. et F.M. Knuth }\end{array}$ & & \\
\hline Cactaceae & Ferocactus & macrodiscus & (Mart.) Britton et Rose & & \\
\hline Cactaceae & Ferocactus & recurvus & (Mill.) Borg & & \\
\hline Cactaceae & Ferocactus & robustus & $\begin{array}{l}\text { (Karw. ex Pfeiff.) Britton et } \\
\text { Rose }\end{array}$ & & \\
\hline Cactaceae & Heliocereus & elegantissimus & Britton et Rose & & \\
\hline Cactaceae & Heliocereus & schrankii & $\begin{array}{l}\text { (Zucc. ex Seitz) Britton et } \\
\text { Rose }\end{array}$ & & \\
\hline Cactaceae & Hylocereus & purpusii & (Weing.) Britton et Rose & & \\
\hline Cactaceae & Hylocereus & undatus & (Haw.) Britton et Rose & & \\
\hline Cactaceae & Isolatocereus & dumortieri & (Scheidw.) Backeb. & & \\
\hline Cactaceae & Mammillaria & carnea & Zucc. ex Pfeiff. & & \\
\hline Cactaceae & Mammillaria & haageana & Pfeiff. & & \\
\hline Cactaceae & Mammillaria & sphacelata & Mart. & & \\
\hline Cactaceae & Myrtillocactus & geometrizans & (Mart. ex Pfeiff.) Console & & \\
\hline Cactaceae & Myrtillocactus & schenckii & (J.A. Purpus) Britton et Rose & & \\
\hline Cactaceae & Neobuxbaumia & macrocephala & $\begin{array}{l}\text { (F.A.C. Weber ex K. Schum.) } \\
\text { E.Y. Dawson }\end{array}$ & & \\
\hline Cactaceae & Neobuxbaumia & mezcalaensis & Bravo & & \\
\hline Cactaceae & Neobuxbaumia & tetetzo & $\begin{array}{l}\text { (F.A.C. Weber ex K. Schum.) } \\
\text { Backeb. }\end{array}$ & & \\
\hline Cactaceae & Nopalea & auberi & (Pfeiff.) Salm-Dyck & & \\
\hline Cactaceae & Nopalea & cochenillifera & (L.) Salm-Dyck & & \\
\hline Cactaceae & Opuntia & huajuapensis & Bravo & & \\
\hline Cactaceae & Opuntia & hyptiacantha & F.A.C. Weber & & \\
\hline Cactaceae & Opuntia & kleiniae & DC. & & \\
\hline Cactaceae & Opuntia & lasiacantha & Pfeiff. & & \\
\hline Cactaceae & Opuntia & pilifera & F.A.C. Weber & & \\
\hline
\end{tabular}




\begin{tabular}{|c|c|c|c|c|c|}
\hline Family & Genus & Specific epithet & Species authors & $\begin{array}{l}\text { Infraspecific } \\
\text { rank and epithet }\end{array}$ & $\begin{array}{l}\text { Infraspecific } \\
\text { taxon Authors }\end{array}$ \\
\hline Cactaceae & Opuntia & pumila & Rose & & \\
\hline Cactaceae & Opuntia & streptacantha & Lem. & & \\
\hline Cactaceae & Opuntia & tomentosa & Salm-Dyck & & \\
\hline Cactaceae & Opuntia & decumbens & Salm-Dyck & & \\
\hline Cactaceae & Opuntia & depressa & Rose & & \\
\hline Cactaceae & Opuntia & ficus-indica & (L.) Mill. & & \\
\hline Cactaceae & Opuntia & imbricata & (Haw.) DC. & & \\
\hline Cactaceae & Pachycereus & hollianus & $\begin{array}{l}\text { (F.A.C. Weber ex J.M. } \\
\text { Coult.) Buxb. }\end{array}$ & & \\
\hline Cactaceae & Pachycereus & marginatus & (DC.) Britton et Rose & & \\
\hline Cactaceae & Pachycereus & weberi & (J.M. Coult.) Backeb. & & \\
\hline Cactaceae & Pereskiopsis & rotundifolia & (DC.) Britton et Rose & & \\
\hline Cactaceae & Pilosocereus & chrysacanthus & $\begin{array}{l}\text { (F.A.C. Weber ex K. Schum.) } \\
\text { Byles et G.D. Rowley }\end{array}$ & & \\
\hline Cactaceae & Polaskia & chende & Gibson et Horak & & \\
\hline Cactaceae & Polaskia & chichipe & (Gosselin) Backeb. & & \\
\hline Cactaceae & Pseudomitrocereus & fulviceps & $\begin{array}{l}\text { (F.A.C. Weber ex K. Schum.) } \\
\text { Bravo et Buxb. }\end{array}$ & & \\
\hline Cactaceae & Stenocereus & griseus & (Haw.) Buxb & & \\
\hline Cactaceae & Stenocereus & pruinosus & (Otto ex Pfeiff.) Buxb. & & \\
\hline Cactaceae & Stenocereus & stellatus & (Pfeiff.) Riccob. & & \\
\hline Cactaceae & Stenocereus & treleasei & (Vaupel) Backeb. & & \\
\hline Campanulaceae & Diastatea & micrantha & (Kunth) McVaugh & & \\
\hline Campanulaceae & Lobelia & berlandieri & A.DC. & & \\
\hline Cannaceae & Canna & indica & L. & & \\
\hline Capparaceae & Forchhammeria & macrocarpa & Standl. & & \\
\hline Capparaceae & Polanisia & uniglandulosa & (Cav.) DC. & & \\
\hline Capparaceae & Quadrella & incana & (Kunth) Iltis et Cornejo & & \\
\hline Caprifoliaceae & Sambucus & mexicana & C. Presl ex DC. & & \\
\hline Caprifoliaceae & Vesalea & floribunda & M. Martens et Galeotti & & \\
\hline Caryophyllaceae & Dianthus & caryophyllus & L. & & \\
\hline Caryophyllaceae & Drymaria & laxiflora & Benth. & & \\
\hline Casuarinaceae & Casuarina & equisetifolia & L. & & \\
\hline Celastraceae & Pristimera & celastroides & (Kunth) A.C. Sm. & & \\
\hline Celastraceae & Wimmeria & microphylla & Radlk. & & \\
\hline Celastraceae & Wimmeria & pubescens & Radlk. & & \\
\hline Commelinaceae & Callisia & navicularis & (Ortgies) D.R. Hunt & & \\
\hline Commelinaceae & Commelina & clavata & C.B. Clarke & & \\
\hline Commelinaceae & Commelina & coelestis & Willd. & & \\
\hline Commelinaceae & Commelina & erecta & L. & & \\
\hline Commelinaceae & Commelina & tuberosa & L. & & \\
\hline Commelinaceae & Gibasis & consobrina & D.R. Hunt & & \\
\hline Commelinaceae & Gibasis & linearis & (Benth.) Rohweder & & \\
\hline Commelinaceae & Tradescantia & crassifolia & Cav. & & \\
\hline Commelinaceae & Tradescantia & sillamontana & Matuda & & \\
\hline
\end{tabular}




\begin{tabular}{|c|c|c|c|c|c|}
\hline Family & Genus & Specific epithet & Species authors & $\begin{array}{l}\text { Infraspecific } \\
\text { rank and epithet }\end{array}$ & $\begin{array}{l}\text { Infraspecific } \\
\text { taxon Authors }\end{array}$ \\
\hline Commelinaceae & Tradescantia & zebrina & Bosse & & \\
\hline Commelinaceae & Tradescantia & pallida & (Rose) D.R. Hunt & & \\
\hline Commelinaceae & Tripogandra & purpurascens & (Schauer) Handlos & & \\
\hline Compositae & Acourtia & lobulata & (Bacig.) Reveal et R.M. King & & \\
\hline Compositae & Acourtia & scapiformis & (Bacig.) B.L. Turner & & \\
\hline Compositae & Ageratina & espinosarum & $\begin{array}{l}\text { (A. Gray) R.M. King et H. } \\
\text { Rob. }\end{array}$ & & \\
\hline Compositae & Ageratina & hebes & $\begin{array}{l}\text { (B.L. Rob.) R.M. King et H. } \\
\text { Rob. }\end{array}$ & & \\
\hline Compositae & Ageratina & mairetiana & (DC.) R.M. King et H. Rob. & & \\
\hline Compositae & Ageratum & tehuacanum & R.M. King et H. Rob. & & \\
\hline Compositae & Archibaccharis & serratifolia & (Kunth) S.F. Blake & & \\
\hline Compositae & Artemisia & absinthium & L. & & \\
\hline Compositae & Artemisia & vulgaris & L. & & \\
\hline Compositae & Aster & novi-belgii & L. & & \\
\hline Compositae & Aster & subulatus & (Michx.) Hort. ex Michx. & & \\
\hline Compositae & Baccharis & conferta & Kunth & & \\
\hline Compositae & Baccharis & mexicana & Cuatrec. & & \\
\hline Compositae & Baccharis & salicina & Torr. et A. Gray & & \\
\hline Compositae & Barkleyanthus & salicifolius & (Kunth) H. Rob. et Brettell & & \\
\hline Compositae & Bidens & bigelovii & A. Gray & & \\
\hline Compositae & Bidens & bipinnata & L. & & \\
\hline Compositae & Bidens & pilosa & L. & & \\
\hline Compositae & Brickellia & scoparia & (DC.) A. Gray & & \\
\hline Compositae & Brickellia & veronicifolia & (Kunth) A. Gray & & \\
\hline Compositae & Calea & zacatechichi & Schltdl. & & \\
\hline Compositae & Calea & oliveri & B.L. Rob. et Greenm. & & \\
\hline Compositae & Calendula & officinalis & L. & & \\
\hline Compositae & Carminatia & alvarezii & Rzed. et Calderón & & \\
\hline Compositae & Chaptalia & nutans & (L.) Polák & & \\
\hline Compositae & Chrysactinia & mexicana & A. Gray & & \\
\hline Compositae & Chrysanthemum & indicum & Thunb. & & \\
\hline Compositae & Cirsium & mexicanum & DC. & & \\
\hline Compositae & Conyza & coronopifolia & Kunth & & \\
\hline Compositae & Cosmos & bipinnatus & Cav. & & \\
\hline Compositae & Dahlia & apiculata & (Sherff) P.D. Sørensen & & \\
\hline Compositae & Dahlia & coccinea & Cav. & & \\
\hline Compositae & Dahlia & merckii & Lehm. & & \\
\hline Compositae & Desmanthodium & ovatum & Benth. & & \\
\hline Compositae & Dyssodia & papposa & (Vent.) Hitchc. & & \\
\hline Compositae & Dyssodia & tagetiflora & Lag. & & \\
\hline Compositae & Erigeron & karvinskianus & DC. & & \\
\hline Compositae & Erigeron & longipes & DC. & & \\
\hline Compositae & Erigeron & bonariensis & L. & & \\
\hline
\end{tabular}




\begin{tabular}{|c|c|c|c|c|c|}
\hline Family & Genus & Specific epithet & Species authors & $\begin{array}{l}\text { Infraspecific } \\
\text { rank and epithet }\end{array}$ & $\begin{array}{l}\text { Infraspecific } \\
\text { taxon Authors }\end{array}$ \\
\hline Compositae & Erigeron & canadensis & L. & & \\
\hline Compositae & Flaveria & trinervia & (Spreng.) C. Mohr & & \\
\hline Compositae & Florestina & simplicifolia & B.L. Turner & & \\
\hline Compositae & Galinsoga & parviflora & Cav. & & \\
\hline Compositae & Gnaphalium & attenuatum & DC. & & \\
\hline Compositae & Gnaphalium & canescens & DC. & & \\
\hline Compositae & Gochnatia & hypoleuca & (DC.) A. Gray & & \\
\hline Compositae & Grindelia & inuloides & Willd. & & \\
\hline Compositae & Gymnolaena & oaxacana & (Greenm.) Rydb. & & \\
\hline Compositae & Gymnosperma & glutinosum & (Spreng.) Less. & & \\
\hline Compositae & Helenium & mexicanum & DC. & & \\
\hline Compositae & Helianthus & annuus & L. & & \\
\hline Compositae & Heterosperma & pinnatum & Cav. & & \\
\hline Compositae & Heterotheca & inuloides & Cass. & & \\
\hline Compositae & Laennecia & sophiifolia & (Kunth) G.L. Nesom & & \\
\hline Compositae & Lagascea & helianthifolia & Kunth & & \\
\hline Compositae & Launaea & intybacea & (Jacq.) Beauverd & & \\
\hline Compositae & Matricaria & chamomilla & L. & & \\
\hline Compositae & Melampodium & divaricatum & (Rich. ex Rich.) DC. & & \\
\hline Compositae & Melampodium & longifolium & Cerv. ex Cav. & & \\
\hline Compositae & Montanoa & mollissima & Brongn. ex Brongn. & & \\
\hline Compositae & Montanoa & tomentosa & Cerv. & & \\
\hline Compositae & Neurolaena & lobata & (L.) R.Br. ex Cass. & & \\
\hline Compositae & Parthenium & bipinnatifidum & (Ortega) Rollins & & \\
\hline Compositae & Parthenium & hysterophorus & Adans. & & \\
\hline Compositae & Parthenium & tomentosum & DC. & & \\
\hline Compositae & Perymenium & discolor & Sch.Bip. & & \\
\hline Compositae & Perymenium & mendezii & DC. & & \\
\hline Compositae & Philactis & zinnioides & Schrad. & & \\
\hline Compositae & Pinaropappus & roseus & (Less.) Less. & & \\
\hline Compositae & Piqueria & trinervia & Cav. & & \\
\hline Compositae & Pluchea & salicifolia & (Mill.) S.F. Blake & & \\
\hline Compositae & Podachaenium & eminens & (Lag.) Sch.Bip. ex Sch.Bip. & & \\
\hline Compositae & Porophyllum & linaria & (Cav.) DC. & & \\
\hline Compositae & Porophyllum & punctatum & (Mill.) S.F. Blake & & \\
\hline Compositae & Porophyllum & ruderale & M. Gómez & & \\
\hline Compositae & Porophyllum & viridiflorum & (Kunth) DC. & & \\
\hline Compositae & Psacalium & amplifolium & (DC.) H. Rob. et Brettell & & \\
\hline Compositae & Pseudelephantopus & spicatus & $\begin{array}{l}\text { (B. Juss. ex Aubl.) Rohr ex } \\
\text { C.F. Baker }\end{array}$ & & \\
\hline Compositae & Sanvitalia & fruticosa & Hemsl. & & \\
\hline Compositae & Sanvitalia & procumbens & Lam. & & \\
\hline Compositae & Schkuhria & pinnata & Cabrera & & \\
\hline Compositae & Senecio & deppeanus & Hemsl. & & \\
\hline
\end{tabular}




\begin{tabular}{|c|c|c|c|c|c|}
\hline Family & Genus & Specific epithet & Species authors & $\begin{array}{l}\text { Infraspecific } \\
\text { rank and epithet }\end{array}$ & $\begin{array}{l}\text { Infraspecific } \\
\text { taxon Authors }\end{array}$ \\
\hline Compositae & Senecio & salignus & DC. & & \\
\hline Compositae & Simsia & lagascaeformis & DC. & & \\
\hline Compositae & Simsia & sanguinea & A. Gray & & \\
\hline Compositae & Sonchus & oleraceus & (L.) L. & & \\
\hline Compositae & Stevia & lucida & Lag. & & \\
\hline Compositae & Stevia & microchaeta & Sch.Bip. ex Sch.Bip. & & \\
\hline Compositae & Stevia & origanoides & Kunth & & \\
\hline Compositae & Stevia & serrata & Cav. & & \\
\hline Compositae & Steviopsis & vigintiseta & (DC.) R.M. King et H. Rob. & & \\
\hline Compositae & Tagetes & erecta & L. & & \\
\hline Compositae & Tagetes & filifolia & Lag. & & \\
\hline Compositae & Tagetes & lucida & Cav. & & \\
\hline Compositae & Tagetes & micrantha & Cav. & & \\
\hline Compositae & Tanacetum & parthenium & (L.) Sch.Bip. & & \\
\hline Compositae & Taraxacum & campylodes & G.E. Haglund & & \\
\hline Compositae & Tithonia & tubaeformis & (Jacq.) Cass. & & \\
\hline Compositae & Tridax & coronopifolia & (Kunth) Hemsl. & & \\
\hline Compositae & Tridax & luisana & Brandegee & & \\
\hline Compositae & Tridax & mexicana & A.M. Powell & & \\
\hline Compositae & Trigonospermum & melampodioides & DC. & & \\
\hline Compositae & Trixis & pringlei & B.L. Rob. et Greenm. & & \\
\hline Compositae & Verbesina & gracilipes & B.L. Rob. & & \\
\hline Compositae & Verbesina & petrophila & Brandegee & & \\
\hline Compositae & Verbesina & serrata & Cav. & var. pringlei & $\begin{array}{l}\text { (B.L. Rob.) B.L. } \\
\text { Rob. et } \\
\text { Greenm. }\end{array}$ \\
\hline Compositae & Verbesina & virgata & Cav. & & \\
\hline Compositae & Vernonia & karvinskiana & DC. & & \\
\hline Compositae & Viguiera & cordata & (Hook. et Arn.) D'Arcy & & \\
\hline Compositae & Viguiera & dentata & (Cav.) Spreng. & & \\
\hline Compositae & Viguiera & grammatoglossa & DC. & & \\
\hline Compositae & Viguiera & pinnatilobata & (Sch.Bip.) S.F. Blake & & \\
\hline Compositae & Viguiera & purpusii & Brandegee & & \\
\hline Compositae & Zinnia & peruviana & (L.) L. & & \\
\hline Compositae & Zinnia & violacea & Cav. & & \\
\hline Convolvulaceae & Cuscuta & corymbosa & Ruiz et Pav. & & \\
\hline Convolvulaceae & Dichondra & sericea & Sw. & & \\
\hline Convolvulaceae & Iротоеа & arborescens & $\begin{array}{l}\text { (Humb. et Bonpl. ex Willd.) } \\
\text { G. Don }\end{array}$ & & \\
\hline Convolvulaceae & Iротоеа & batatas & (L.) Lam. & & \\
\hline Convolvulaceae & Ipomoea & cholulensis & Kunth & & \\
\hline Convolvulaceae & Iротоеа & coccinea & L. & & \\
\hline Convolvulaceae & Ipomoea & conzattii & Greenm. & & \\
\hline Convolvulaceae & Iротоеа & leptotoma & Torr. & & \\
\hline Convolvulaceae & Ipomoea & murucoides & Roem. et Schult. & & \\
\hline
\end{tabular}




\begin{tabular}{|c|c|c|c|c|c|}
\hline Family & Genus & Specific epithet & Species authors & $\begin{array}{l}\text { Infraspecific } \\
\text { rank and epithet }\end{array}$ & $\begin{array}{l}\text { Infraspecific } \\
\text { taxon Authors }\end{array}$ \\
\hline Convolvulaceae & Ipomoea & nil & (L.) Roth & & \\
\hline Convolvulaceae & Ipomoea & pauciflora & M. Martens et Galeotti & & \\
\hline Convolvulaceae & Ipomoea & purpurea & (L.) Roth & & \\
\hline Convolvulaceae & Ipomoea & tricolor & Cav. & & \\
\hline Convolvulaceae & Jacquemontia & smithii & B.L. Rob. et Greenm. & & \\
\hline Convolvulaceae & Turbina & corymbosa & (L.) Raf. & & \\
\hline Crassulaceae & Bryophyllum & pinnatum & (Lam.) Oken & & \\
\hline Crassulaceae & Echeveria & gibbiflora & DC. & & \\
\hline Crassulaceae & Echeveria & gracilis & Rose ex E. Walther & & \\
\hline Crassulaceae & Echeveria & heterosepala & Rose & & \\
\hline Crassulaceae & Echeveria & nodulosa & (Baker) Otto & & \\
\hline Crassulaceae & Echeveria & nuda & Lindl. & & \\
\hline Crassulaceae & Echeveria & peacockii & Croucher & & \\
\hline Crassulaceae & Echeveria & pulvinata & Rose & & \\
\hline Crassulaceae & Echeveria & purpusorum & (Rose) A. Berger & & \\
\hline Crassulaceae & Echeveria & setosa & Rose et Purpus & & \\
\hline Crassulaceae & Echeveria & pallida & E. Walther & & \\
\hline Crassulaceae & Graptopetalum & mexicanum & Matuda & & \\
\hline Crassulaceae & Kalanchoe & blossfeldiana & Poelln. & & \\
\hline Crassulaceae & Kalanchoe & daigremontiana & Raym.-Hamet et H. Perrier & & \\
\hline Crassulaceae & Kalanchoe & mortagei & Raym.-Hamet et H. Perrier & & \\
\hline Crassulaceae & Kalanchoe & pinnata & (Lam.) Pers. & & \\
\hline Crassulaceae & Sedum & calcicola & B.L. Rob. et Greenm. & & \\
\hline Crassulaceae & Sedum & mexicanum & Britton & & \\
\hline Crassulaceae & Sedum & morganianum & E. Walther & & \\
\hline Crassulaceae & Sedum & praealtum & A. DC. & & \\
\hline Crassulaceae & Sedum & allantoides & Rose & & \\
\hline Crassulaceae & Sedum & dendroideum & Moc. et Sessé ex DC. & & \\
\hline Crassulaceae & Thompsonella & minutiflora & (Rose) Britton et Rose & & \\
\hline Cucurbitaceae & Apodanthera & undulata & A. Gray & var. australis & McVaugh \\
\hline Cucurbitaceae & Citrullus & lanatus & (Thunb.) Matsum. et Nakai & & \\
\hline Cucurbitaceae & Cucumis & anguria & L. & & \\
\hline Cucurbitaceae & Cucumis & melo & L. & & \\
\hline Cucurbitaceae & Cucumis & sativus & L. & & \\
\hline Cucurbitaceae & Cucurbita & argyrosperma & C. Huber & & \\
\hline Cucurbitaceae & Cucurbita & ficifolia & Bouché & & \\
\hline Cucurbitaceae & Cucurbita & moschata & Duchesne & & \\
\hline Cucurbitaceae & Cucurbita & реро & L. & & \\
\hline Cucurbitaceae & Cyclanthera & dissecta & (Torr. et A. Gray) Arn. & & \\
\hline Cucurbitaceae & Echinopepon $X$ & pubescens & (Cogn.) Rose & & \\
\hline Cucurbitaceae & Lagenaria & siceraria & (Molina) Standl. & & \\
\hline Cucurbitaceae & Luffa & aegyptiaca & Mill. & & \\
\hline Cucurbitaceae & Melothria & pendula & L. & & \\
\hline Cucurbitaceae & Microsechium & palmatum & (Ser.) Cogn. & & \\
\hline
\end{tabular}




\begin{tabular}{|c|c|c|c|c|c|}
\hline Family & Genus & Specific epithet & Species authors & $\begin{array}{l}\text { Infraspecific } \\
\text { rank and epithet }\end{array}$ & $\begin{array}{l}\text { Infraspecific } \\
\text { taxon Authors }\end{array}$ \\
\hline Cucurbitaceae & Parasicyos & dieterleae & Lira et R. Torres & & \\
\hline Cucurbitaceae & Sicyos & laciniatus & Hillebr. & & \\
\hline Cucurbitaceae & Sicyos & parviflorus & Willd. & & \\
\hline Cupressaceae & Cupressus & lindleyi & Klotzsch ex Endl. & & \\
\hline Cupressaceae & Cupressus & lusitanica & Mill. & & \\
\hline Cupressaceae & Cupressus & lusitanica & Mill. & var. benthamii & (Endl.) Carrière \\
\hline Cupressaceae & Cupressus & sempervirens & L. & & \\
\hline Cupressaceae & Juniperus & communis & L. & & \\
\hline Cupressaceae & Juniperus & deppeana & Steud. & & \\
\hline Cupressaceae & Juniperus & flaccida & Schltdl. & & \\
\hline Cyperaceae & Bulbostylis & capillaris & (L.) Kunth ex C.B. Clarke & & \\
\hline Cyperaceae & Bulbostylis & junciformis & (Kunth) C.B. Clarke & & \\
\hline Cyperaceae & Bulbostylis & juncoides & (Vahl) Kük. ex Herter & & \\
\hline Cyperaceae & Carex & anisostachys & Liebm. & & \\
\hline Cyperaceae & Carex & humboldtiana & Steud. & & \\
\hline Cyperaceae & Carex & longicaulis & Boeckeler & & \\
\hline Cyperaceae & Carex & planostachys & Kunze & & \\
\hline Cyperaceae & Carex & scabrella & Wahlenb. & & \\
\hline Cyperaceae & Carex & schiedeana & Kunze & & \\
\hline Cyperaceae & Carex & standleyana & Steyerm. & & \\
\hline Cyperaceae & Carex & turbinata & Liebm. & & \\
\hline Cyperaceae & Carex & muehlenbergii & Willd. & var. xalapensis & (Kunth) Britton \\
\hline Cyperaceae & Cyperus & aggregatus & (Willd.) Endl. & & \\
\hline Cyperaceae & Cyperus & ciliatus & Jungh. & & \\
\hline Cyperaceae & Cyperus & elegans & L. & & \\
\hline Cyperaceae & Cyperus & esculentus & L. & & \\
\hline Cyperaceae & Cyperus & flavescens & L. & & \\
\hline Cyperaceae & Cyperus & hermaphroditus & (Jacq.) Standl. & & \\
\hline Cyperaceae & Cyperus & laevigatus & L. & & \\
\hline Cyperaceae & Cyperus & manimae & Kunth & & \\
\hline Cyperaceae & Cyperus & niger & Ruiz et Pav. & & \\
\hline Cyperaceae & Cyperus & ochraceus & Vahl & & \\
\hline Cyperaceae & Cyperus & odoratus & Burm.f. & & \\
\hline Cyperaceae & Cyperus & pycnostachyus & (Kunth) Kunth & & \\
\hline Cyperaceae & Cyperus & seslerioides & Kunth & & \\
\hline Cyperaceae & Cyperus & spectabilis & Link & & \\
\hline Cyperaceae & Cyperus & subambiguus & Kük. & & \\
\hline Cyperaceae & Cyperus & surinamensis & Rottb. & & \\
\hline Cyperaceae & Cyperus & tenerrimus & J. Presl et C. Presl & & \\
\hline Cyperaceae & Cyperus & thyrsiflorus & Boeckeler & & \\
\hline Cyperaceae & Cyperus & laxus & Lam. & & \\
\hline Cyperaceae & Eleocharis & acicularis & (L.) Roem. et Schult. & & \\
\hline Cyperaceae & Eleocharis & geniculata & (L.) Roem. et Schult. & & \\
\hline Cyperaceae & Eleocharis & macrostachya & Britton & & \\
\hline
\end{tabular}




\begin{tabular}{|c|c|c|c|c|c|}
\hline Family & Genus & Specific epithet & Species authors & $\begin{array}{l}\text { Infraspecific } \\
\text { rank and epithet }\end{array}$ & $\begin{array}{l}\text { Infraspecific } \\
\text { taxon Authors }\end{array}$ \\
\hline Cyperaceae & Eleocharis & montana & (Kunth) Roem. et Schult. & & \\
\hline Cyperaceae & Eleocharis & montevidensis & Kunth & & \\
\hline Cyperaceae & Fimbristylis & aestivalis & Vahl & & \\
\hline Cyperaceae & Fimbristylis & mexicana & Palla & & \\
\hline Cyperaceae & Fuirena & incompleta & Nees & & \\
\hline Cyperaceae & Fuirena & simplex & Vahl & & \\
\hline Cyperaceae & Pycreus & lanceolatus & (Poir.) C.B. Clarke & & \\
\hline Cyperaceae & Pycreus & niger & (Ruiz et Pav.) Cufod. & & \\
\hline Cyperaceae & Rhynchospora & macrochaeta & Steud. ex Boeckeler & & \\
\hline Cyperaceae & Schoenoplectus & americanus & (Pers.) Volkart & & \\
\hline Cyperaceae & Schoenus & nigricans & L. & & \\
\hline Cyperaceae & Scirpus & polyphyllus & Vahl & & \\
\hline Dioscoreaceae & Dioscorea & convolvulacea & Cham. et Schltdl. & & \\
\hline Ebenaceae & Diospyros & virginiana & L. & & \\
\hline Ebenaceae & Diospyros & oaxacana & Standl. & & \\
\hline Elaeocarpaceae & Muntingia & calabura & L. & & \\
\hline Ephedraceae & Ephedra & compacta & Rose & & \\
\hline Equisetaceae & Equisetum & hyemale & L. & & \\
\hline Equisetaceae & Equisetum & myriochaetum & Schltdl. et Cham. & & \\
\hline Ericaceae & Arbutus & xalapensis & Kunth & & \\
\hline Ericaceae & Arctostaphylos & pungens & Kunth & & \\
\hline Ericaceae & Comarostaphylis & polifolia & (Kunth) Zucc. ex Klotzsch & & \\
\hline Ericaceae & Vaccinium & confertum & Kunth & & \\
\hline Ericaceae & Vaccinium & leucanthum & Schltdl. & & \\
\hline Erythroxylaceae & Erythroxylum & compactum & Rose & & \\
\hline Euphorbiaceae & Acalypha & phleoides & Cav. & & \\
\hline Euphorbiaceae & Acalypha & purpurascens & Kunth & & \\
\hline Euphorbiaceae & Acalypha & monostachya & Cav. & & \\
\hline Euphorbiaceae & Cnidoscolus & tehuacanensis & Breckon & & \\
\hline Euphorbiaceae & Cnidoscolus & aconitifolius & (Mill.) I.M. Johnst. & & \\
\hline Euphorbiaceae & Croton & ciliatoglandulifer & Ortega & & \\
\hline Euphorbiaceae & Croton & morifolius & Willd. & & \\
\hline Euphorbiaceae & Euphorbia & antisyphilitica & Zucc. & & \\
\hline Euphorbiaceae & Euphorbia & cumbrae & Boiss. & & \\
\hline Euphorbiaceae & Euphorbia & dentata & Michx. & & \\
\hline Euphorbiaceae & Euphorbia & graminea & Schltdl. et Cham. & & \\
\hline Euphorbiaceae & Euphorbia & heterophylla & L. & & \\
\hline Euphorbiaceae & Euphorbia & lactea & Haw. & & \\
\hline Euphorbiaceae & Euphorbia & macropus & (Klotzsch et Garcke) Boiss. & & \\
\hline Euphorbiaceae & Euphorbia & peganoides & Boiss. & & \\
\hline Euphorbiaceae & Euphorbia & prostrata & Burch. ex Hemsl. & & \\
\hline Euphorbiaceae & Euphorbia & pulcherrima & Willd. ex Klotzsch & & \\
\hline Euphorbiaceae & Euphorbia & schlechtendalii & Boiss. & & \\
\hline Euphorbiaceae & Euphorbia & tirucalli & L. & & \\
\hline
\end{tabular}




\begin{tabular}{|c|c|c|c|c|c|}
\hline Family & Genus & Specific epithet & Species authors & $\begin{array}{l}\text { Infraspecific } \\
\text { rank and epithet }\end{array}$ & $\begin{array}{l}\text { Infraspecific } \\
\text { taxon Authors }\end{array}$ \\
\hline Euphorbiaceae & Euphorbia & tricolor & Greenm. & & \\
\hline Euphorbiaceae & Euphorbia & berteroana & Balb. ex Spreng. & & \\
\hline Euphorbiaceae & Euphorbia & cumbrae & Boiss. & & \\
\hline Euphorbiaceae & Euphorbia & cymbifera & (Schltdl.) V.W. Steinm. & & \\
\hline Euphorbiaceae & Euphorbia & dioeca & Kunth & & \\
\hline Euphorbiaceae & Euphorbia & milii & Des Moul. & var. splendens & $\begin{array}{l}\text { (Bojer ex } \\
\text { Hook.) Ursch } \\
\text { et Leandri }\end{array}$ \\
\hline Euphorbiaceae & Jatropha & dioica & Sessé & & \\
\hline Euphorbiaceae & Jatropha & neopauciflora & $\operatorname{Pax}$ & & \\
\hline Euphorbiaceae & Jatropha & spathulata & (Ortega) Müll.Arg. & & \\
\hline Euphorbiaceae & Manihot & pauciflora & Brandegee & & \\
\hline Euphorbiaceae & Ricinus & communis & L. & & \\
\hline Euphorbiaceae & Sebastiania & bilocularis & S. Watson & & \\
\hline Euphorbiaceae & Sebastiania & pavoniana & (Müll.Arg.) Müll.Arg. & & \\
\hline Fouquieriaceae & Fouquieria & formosa & Kunth & & \\
\hline Fouquieriaceae & Fouquieria & purpusii & Brandegee & & \\
\hline Garryaceae & Garrya & laurifolia & Benth. & & \\
\hline Garryaceae & Garrya & ovata & Benth. & & \\
\hline Geraniaceae & Erodium & cicutarium & (L.) L’Hér. & & \\
\hline Geraniaceae & Geranium & schiedeanum & Schltdl. & & \\
\hline Geraniaceae & Pelargonium & hortorum & L.H. Bailey & & \\
\hline Gesneriaceae & Episcia & cupreata & (Hook.) Hanst. & & \\
\hline Hernandiaceae & Gyrocarpus & mocinoi & Espejo & & \\
\hline Hypoxidaceae & Hypoxis & decumbens & Lam. & & \\
\hline Iridaceae & Crocosmia & crocosmiiflora & (Lemoine) N.E. Br. & & \\
\hline Iridaceae & Iris & germanica & L. & & \\
\hline Iridaceae & Tigridia & pavonia & (L.f.) DC. & & \\
\hline Krameriaceae & Krameria & cytisoides & Cav. & & \\
\hline Lamiaceae & Clinopodium & mexicanum & (Benth.) Govaerts & & \\
\hline Lamiaceae & Leonotis & nepetifolia & (L.) R. Br. & & \\
\hline Lamiaceae & Lepechinia & mexicana & (S. Schauer) Epling & & \\
\hline Lamiaceae & Marrubium & vulgare & L. & & \\
\hline Lamiaceae & Ocimum & basilicum & L. & & \\
\hline Lamiaceae & Plectranthus & scutellarioides & (L.) R. Br. & & \\
\hline Lamiaceae & Salvia & aspera & M. Martens et Galeotti & & \\
\hline Lamiaceae & Salvia & cacaliifolia & Benth. & & \\
\hline Lamiaceae & Salvia & candicans & M. Martens et Galeotti & & \\
\hline Lamiaceae & Salvia & hispanica & L. & & \\
\hline Lamiaceae & Salvia & oaxacana & Fernald & & \\
\hline Lamiaceae & Salvia & pannosa & Fernald & & \\
\hline Lamiaceae & Salvia & podadena & Briq. & & \\
\hline Lamiaceae & Salvia & purpurea & Sessé et Moc. & & \\
\hline Lamiaceae & Salvia & sessei & Benth. & & \\
\hline
\end{tabular}




\begin{tabular}{|c|c|c|c|c|c|}
\hline Family & Genus & Specific epithet & Species authors & $\begin{array}{l}\text { Infraspecific } \\
\text { rank and epithet }\end{array}$ & $\begin{array}{l}\text { Infraspecific } \\
\text { taxon Authors }\end{array}$ \\
\hline Lamiaceae & Salvia & thymoides & Benth. & & \\
\hline Lamiaceae & Salvia & tiliifolia & Vahl & & \\
\hline Lamiaceae & Salvia & villosa & Fernald & & \\
\hline Lamiaceae & Salvia & brevilabra & Franch. & & \\
\hline Lamiaceae & Salvia & circinnata & Cav. & & \\
\hline Lamiaceae & Stachys & inclusa & Epling & & \\
\hline Leguminosae & Acacia & acatlensis & Benth. & & \\
\hline Leguminosae & Acacia & angustissima & (Mill.) Kuntze & & \\
\hline Leguminosae & Acacia & bilimekii & J.F. Macbr. & & \\
\hline Leguminosae & Acacia & cochliacantha & Willd. & & \\
\hline Leguminosae & Acacia & compacta & Rose & & \\
\hline Leguminosae & Acacia & constricta & A. Gray & & \\
\hline Leguminosae & Acacia & coulteri & A. Gray & & \\
\hline Leguminosae & Acacia & farnesiana & (L.) Willd. & & \\
\hline Leguminosae & Acacia & macracantha & Willd. & & \\
\hline Leguminosae & Acacia & mammifera & Schltdl. & & \\
\hline Leguminosae & Acacia & pennatula & (Schltdl. et Cham.) Benth. & & \\
\hline Leguminosae & Acacia & pringlei & Rose & & \\
\hline Leguminosae & Acacia & schaffneri & (S. Watson) F.J. Herm. & & \\
\hline Leguminosae & Acacia & subangulata & Rose & & \\
\hline Leguminosae & Acacia & tequilana & S. Watson & & \\
\hline Leguminosae & Acacia & velvae & L. Rico & & \\
\hline Leguminosae & Aeschynomene & compacta & Rose & & \\
\hline Leguminosae & Aeschynomene & fascicularis & Cham. et Schltdl. & & \\
\hline Leguminosae & Aeschynomene & purpusii & Brandegee & & \\
\hline Leguminosae & Bauhinia & deserti & (Britton et Rose) Lundell & & \\
\hline Leguminosae & Bauhinia & divaricata & L. & & \\
\hline Leguminosae & Brongniartia & oligosperma & Baill. & & \\
\hline Leguminosae & Caesalpinia & cacalaco & Humb. et Bonpl. & & \\
\hline Leguminosae & Caesalpinia & melanadenia & (Rose) Standl. & & \\
\hline Leguminosae & Caesalpinia & pulcherrima & (L.) Sw. & & \\
\hline Leguminosae & Caesalpinia & velutina & (Britton et Rose) Standl. & & \\
\hline Leguminosae & Cajanus & cajan & (L.) Millsp. & & \\
\hline Leguminosae & Calliandra & eriophylla & Benth. & & \\
\hline Leguminosae & Calliandra & houstoniana & (Mill.) Standl. & var. anomala & $\begin{array}{l}\text { (Kunth) } \\
\text { Barneby }\end{array}$ \\
\hline Leguminosae & Calliandropsis & nervosus & $\begin{array}{l}\text { (Britton et Rose) H.M. Hern. } \\
\text { et P. Guinet }\end{array}$ & & \\
\hline Leguminosae & Canavalia & hirsutissima & J.D. Sauer & & \\
\hline Leguminosae & Canavalia & villosa & Benth. & & \\
\hline Leguminosae & Cologania & angustifolia & Kunth & & \\
\hline Leguminosae & Cologania & broussonetii & (Balb.) DC. & & \\
\hline Leguminosae & Conzattia & multiflora & (Robinson) Standl. & & \\
\hline Leguminosae & Conzattia & multiflora & (Robinson) Standl. & & \\
\hline Leguminosae & Coursetia & glandulosa & A. Gray & & \\
\hline
\end{tabular}




\begin{tabular}{|c|c|c|c|c|c|}
\hline Family & Genus & Specific epithet & Species authors & $\begin{array}{l}\text { Infraspecific } \\
\text { rank and epithet }\end{array}$ & $\begin{array}{l}\text { Infraspecific } \\
\text { taxon Authors }\end{array}$ \\
\hline Leguminosae & Crotalaria & incana & L. & & \\
\hline Leguminosae & Crotalaria & longirostrata & Hook. et Arn. & & \\
\hline Leguminosae & Crotalaria & pumila & Ortega & & \\
\hline Leguminosae & Crotalaria & rotundifolia & J.F. Gmel. & & \\
\hline Leguminosae & Crotalaria & sagittalis & L. & & \\
\hline Leguminosae & Dalea & bicolor & Willd. & & \\
\hline Leguminosae & Dalea & caeciliae & Harms & & \\
\hline Leguminosae & Dalea & carthagenensis & (Jacq.) J.F. Macbr. & & \\
\hline Leguminosae & Dalea & carthagenensis & J.F. Macbr. & var. capitulata & (Rydb.) Barneby \\
\hline Leguminosae & Dalea & greggii & A. Gray & & \\
\hline Leguminosae & Dalea & tomentosa & (Cav.) Willd. & & \\
\hline Leguminosae & Delonix & regia & (Hook.) Raf. & & \\
\hline Leguminosae & Desmanthus & painteri & (Britton et Rose) Standl. & & \\
\hline Leguminosae & Desmanthus & virgatus & (L.) Willd. & & \\
\hline Leguminosae & Desmodium & axillare & (Sw.) DC. & & \\
\hline Leguminosae & Desmodium & conzattii & Greenm. & & \\
\hline Leguminosae & Desmodium & glabrum & (Mill.) DC. & & \\
\hline Leguminosae & Desmodium & molliculum & (Kunth) DC. & & \\
\hline Leguminosae & Desmodium & orbiculare & Schltdl. & & \\
\hline Leguminosae & Desmodium & prehensile & Schltdl. & & \\
\hline Leguminosae & Desmodium & procumbens & (Mill.) Hitchc. & & \\
\hline Leguminosae & Desmodium & sericophyllum & Schltdl. & & \\
\hline Leguminosae & Desmodium & subsessile & Schltdl. & & \\
\hline Leguminosae & Desmodium & amplifolium & Hemsl. & & \\
\hline Leguminosae & Enterolobium & cyclocarpum & (Jacq.) Griseb. & & \\
\hline Leguminosae & Eriosema & pulchellum & (Kunth) G. Don & & \\
\hline Leguminosae & Erythrina & americana & Mill. & & \\
\hline Leguminosae & Erythrina & coralloides & DC. & & \\
\hline Leguminosae & Eysenhardtia & polystachya & (Ortega) Sarg. & & \\
\hline Leguminosae & Galactia & brachystachys & Benth. & & \\
\hline Leguminosae & Galactia & multiflora & Robinson & & \\
\hline Leguminosae & Haematoxylum & brasiletto & H. Karst. & & \\
\hline Leguminosae & Harpalyce & formosa & DC. & & \\
\hline Leguminosae & Hybosema & ehrenbergii & (Schltdl.) Harms & & \\
\hline Leguminosae & Indigofera & conzattii & Rose & & \\
\hline Leguminosae & Indigofera & densiflora & M. Martens et Galeotti & & \\
\hline Leguminosae & Indigofera & suffruticosa & Mill. & & \\
\hline Leguminosae & Leucaena & confertiflora & Zarate & & \\
\hline Leguminosae & Leucaena & diversifolia & (Schltdl.) Benth. & & \\
\hline Leguminosae & Leucaena & esculenta & (DC.) Benth. & & \\
\hline Leguminosae & Leucaena & lanceolata & S. Watson & & \\
\hline Leguminosae & Leucaena & leucocephala & (Lam.) de Wit & & \\
\hline Leguminosae & Leucaena & diversifolia & (Schltdl.) Benth. & & \\
\hline Leguminosae & Indigofera & miniata & Ortega & & \\
\hline
\end{tabular}




\begin{tabular}{|c|c|c|c|c|c|}
\hline Family & Genus & Specific epithet & Species authors & $\begin{array}{l}\text { Infraspecific } \\
\text { rank and epithet }\end{array}$ & $\begin{array}{l}\text { Infraspecific } \\
\text { taxon Authors }\end{array}$ \\
\hline Leguminosae & Lupinus & uncinatus & Schltdl. & & \\
\hline Leguminosae & Lysiloma & acapulcense & (Kunth) Benth. & & \\
\hline Leguminosae & Lysiloma & divaricatum & (Jacq.) J.F. Macbr. & & \\
\hline Leguminosae & Macroptilium & atropurpureum & (DC.) Urb. & & \\
\hline Leguminosae & Medicago & polymorpha & L. & & \\
\hline Leguminosae & Medicago & sativa & L. & & \\
\hline Leguminosae & Melilotus & indicus & (L.) All. & & \\
\hline Leguminosae & Mimosa & albida & Willd. & & \\
\hline Leguminosae & Mimosa & lacerata & Rose & & \\
\hline Leguminosae & Mimosa & luisana & Brandegee & & \\
\hline Leguminosae & Nissolia & fruticosa & Jacq. & & \\
\hline Leguminosae & Nissolia & microptera & Poir. & & \\
\hline Leguminosae & Pachyrhizus & erosus & Urb. & & \\
\hline Leguminosae & Parkinsonia & praecox & (Ruiz et Pav.) Hawkins & & \\
\hline Leguminosae & Phaseolus & vulgaris & L. & & \\
\hline Leguminosae & Phaseolus & coccineus & L. & & \\
\hline Leguminosae & Piscidia & grandifolia & (Donn. Sm.) I.M. Johnst. & & \\
\hline Leguminosae & Pisum & sativum & L. & & \\
\hline Leguminosae & Pithecellobium & dulce & (Roxb.) Benth. & & \\
\hline Leguminosae & Prosopis & laevigata & (Willd.) M.C. Johnst. & & \\
\hline Leguminosae & Rhynchosia & longeracemosa & M. Martens et Galeotti & & \\
\hline Leguminosae & Rhynchosia & pringlei & Rose & & \\
\hline Leguminosae & Rhynchosia & pyramidalis & (Lam.) Urb. & & \\
\hline Leguminosae & Rhynchosia & senna & Hook. & & \\
\hline Leguminosae & Senna & apiculata & $\begin{array}{l}\text { (M. Martens et Galeotti) H.S. } \\
\text { Irwin }\end{array}$ & & \\
\hline Leguminosae & Senna & atomaria & (L.) H.S. Irwin et Barneby & & \\
\hline Leguminosae & Senna & guatemalensis & $\begin{array}{l}\text { (Donn. Sm.) H.S. Irwin et } \\
\text { Barneby }\end{array}$ & & \\
\hline Leguminosae & Senna & unijuga & (Rose) H.S. Irwin et Barneby & & \\
\hline Leguminosae & Senna & wislizenii & (L.) Roxb. & & \\
\hline Leguminosae & Senna & holwayana & (Rose) H.S. Irwin et Barneby & & \\
\hline Leguminosae & Sophora & secundiflora & (Ortega) DC. & & \\
\hline Leguminosae & Sphinga & acatlensis & $\begin{array}{l}\text { (Benth.) Barneby et J.W. } \\
\text { Grimes }\end{array}$ & & \\
\hline Leguminosae & Tamarindus & indica & L. & & \\
\hline Leguminosae & Tephrosia & nicaraguensis & Oerst. & & \\
\hline Leguminosae & Vicia & faba & L. & & \\
\hline Leguminosae & Zapoteca & formosa & (Kunth) H.M. Hern. & & \\
\hline Leguminosae & Zornia & reticulata & Sm. & & \\
\hline Lentibulariaceae & Pinguicula & moranensis & Kunth & & \\
\hline Loasaceae & Eucnide & grandiflora & (Groenl.) Rose & & \\
\hline Loasaceae & Gronovia & scandens & L. & & \\
\hline Loasaceae & Mentzelia & hispida & Willd. & & \\
\hline Loganiaceae & Plocosperma & buxifolium & Benth. & & \\
\hline
\end{tabular}




\begin{tabular}{|c|c|c|c|c|c|}
\hline Family & Genus & Specific epithet & Species authors & $\begin{array}{l}\text { Infraspecific } \\
\text { rank and epithet }\end{array}$ & $\begin{array}{l}\text { Infraspecific } \\
\text { taxon Authors }\end{array}$ \\
\hline Loranthaceae & Phoradendron & californicum & Nutt. & & \\
\hline Loranthaceae & Phoradendron & dipterum & Eichler & & \\
\hline Lythraceae & Cuphea & aequipetala & Cav. & & \\
\hline Lythraceae & Cuphea & wrightii & A. Gray & & \\
\hline Lythraceae & Punica & granatum & L. & & \\
\hline Malpighiaceae & Bunchosia & biocellata & Schltdl. & & \\
\hline Malpighiaceae & Bunchosia & palmeri & S. Watson & & \\
\hline Malpighiaceae & Byrsonima & cinerea & (Poir.) DC. & & \\
\hline Malpighiaceae & Calcicola & parvifolia & $\begin{array}{l}\text { (A. Juss.) W.R. Anderson et } \\
\text { C. Davis }\end{array}$ & & \\
\hline Malpighiaceae & Echinopterys & eglandulosa & (A. Juss.) Small & & \\
\hline Malpighiaceae & Galphimia & glauca & Cav. & & \\
\hline Malpighiaceae & Gaudichaudia & galeottiana & (Nied.) Chodat & & \\
\hline Malvaceae & Althaea & officinalis & L. & & \\
\hline Malvaceae & Anoda & crenatiflora & Ortega & & \\
\hline Malvaceae & Anoda & cristata & (L.) Schltdl. & & \\
\hline Malvaceae & Anoda & guatemalensis & Fryxell & & \\
\hline Malvaceae & Bastardia & viscosa & (L.) Kunth & & \\
\hline Malvaceae & Ceiba & aesculifolia & (Kunth) Britten et Baker f. & & \\
\hline Malvaceae & Ceiba & aesculifolia & (Kunth) Britten et Baker f. & subsp. parvifolia & $\begin{array}{l}\text { (Rose) P.E. } \\
\text { Gibbs et Semir }\end{array}$ \\
\hline Malvaceae & Gossypium & hirsutum & L. & & \\
\hline Malvaceae & Guazuma & ulmifolia & Lam. & & \\
\hline Malvaceae & Heliocarpus & terebinthaceus & L. & & \\
\hline Malvaceae & Heliocarpus & velutina & L. & & \\
\hline Malvaceae & Herissantia & crispa & (L.) Brizicky & & \\
\hline Malvaceae & Hibiscus & elegans & Standl. & & \\
\hline Malvaceae & Hibiscus & phoenicus & L. & & \\
\hline Malvaceae & Hibiscus & rosa-sinensis & L. & & \\
\hline Malvaceae & Kearnemalvastrum & lacteum & (Aiton) D.M. Bates & & \\
\hline Malvaceae & Lavatera & trimestris & L. & & \\
\hline Malvaceae & Malva & parviflora & L. & & \\
\hline Malvaceae & Malvastrum & bicuspidatum & (S. Watson) Rose & & \\
\hline Malvaceae & Melochia & pyramidata & L. & & \\
\hline Malvaceae & Melochia & tomentosa & L. & & \\
\hline Malvaceae & Rhynchosida & physocalyx & (A. Gray) Fryxell & & \\
\hline Malvaceae & Robinsonella & chiangii & Fryxell & & \\
\hline Malvaceae & Robinsonella & speciosa & Fryxell & & \\
\hline Malvaceae & Sida & acuta & Burm.f. & & \\
\hline Malvaceae & Sida & ciliaris & L. & & \\
\hline Malvaceae & Sida & glabra & Mill. & & \\
\hline Malvaceae & Sida & rhombifolia & L. & & \\
\hline Malvaceae & Sidastrum & tehuacanum & (Brandegee) Fryxell & & \\
\hline Malvaceae & Waltheria & americana & L. & & \\
\hline
\end{tabular}




\begin{tabular}{|c|c|c|c|c|c|}
\hline Family & Genus & Specific epithet & Species authors & $\begin{array}{l}\text { Infraspecific } \\
\text { rank and epithet }\end{array}$ & $\begin{array}{l}\text { Infraspecific } \\
\text { taxon Authors }\end{array}$ \\
\hline Marantaceae & Maranta & leuconeura & E. Morren & & \\
\hline Marantaceae & Thalia & geniculata & L. & & \\
\hline Meliaceae & Cedrela & aoxacensis & C. DC. et Rose & & \\
\hline Meliaceae & Cedrela & odorata & L. & & \\
\hline Meliaceae & Melia & azedarach & L. & & \\
\hline Moraceae & Ficus & carica & L. & & \\
\hline Moraceae & Ficus & cotinifolia & Kunth & & \\
\hline Moraceae & Ficus & crocata & Mart. ex Miq. & & \\
\hline Moraceae & Ficus & petiolaris & Kunth & & \\
\hline Moraceae & Ficus & trigonata & L. & & \\
\hline Moraceae & Ficus & punctata & Thunb. & & \\
\hline Moraceae & Ficus & velutina & Humb. et Bonpl. ex Willd. & & \\
\hline Moraceae & Maclura & tinctoria & (L.) D. Don ex Steud. & & \\
\hline Moraceae & Morus & alba & L. & & \\
\hline Moraceae & Morus & celtidifolia & Kunth & & \\
\hline Myricaceae & Morella & cerifera & (L.) Small & & \\
\hline Myrtaceae & Eucalyptus & globulus & Labill. & & \\
\hline Myrtaceae & Psidium & guajava & L. & & \\
\hline Nephrolepidaceae & Nephrolepis & exaltata & (L.) Schott & & \\
\hline Nyctaginaceae & Boerhavia & scandens & L. & & \\
\hline Nyctaginaceae & Bougainvillea & spectabilis & Willd. & & \\
\hline Nyctaginaceae & Mirabilis & glabrifolia & (Ortega) I.M. Johnst. & & \\
\hline Nyctaginaceae & Mirabilis & jalapa & L. & & \\
\hline Nyctaginaceae & Okenia & hypogaea & Schltdl. et Cham. & & \\
\hline Oleaceae & Fraxinus & purpusii & Brandegee & & \\
\hline Oleaceae & Fraxinus & uhdei & (Wenz.) Lingelsh. & & \\
\hline Oleaceae & Jasminum & mesnyi & Hance & & \\
\hline Oleaceae & Jasminum & sambac & (L.) Aiton & & \\
\hline Oleaceae & Ligustrum & japonicum & Thunb. & & \\
\hline Onagraceae & Fuchsia & encliandra & (Zucc.) Steud. & & \\
\hline Onagraceae & Gaura & coccinea & Nutt. ex Pursh & & \\
\hline Onagraceae & Ludwigia & octovalvis & (Jacq.) P.H. Raven & & \\
\hline Onagraceae & Oenothera & laciniata & Hill & & \\
\hline Onagraceae & Oenothera & pubescens & Willd. ex Spreng. & & \\
\hline Opiliaceae & Agonandra & obtusifolia & Standl. & & \\
\hline Opiliaceae & Agonandra & racemosa & (DC.) Standl. & & \\
\hline Orchidaceae & Barkeria & lindleyana & Bateman ex Lindl. & & \\
\hline Orchidaceae & Dichromanthus & cinnabarinus & (Lex.) Garay & & \\
\hline Orchidaceae & Domingoa & purpurea & $\begin{array}{l}\text { (Lindl.) Van den Berg et Soto } \\
\text { Arenas }\end{array}$ & & \\
\hline Orchidaceae & Laelia & albida & Bateman ex Lindl. & & \\
\hline Orchidaceae & Prosthechea & pterocarpa & (Lindl.) W.E. Higgins & & \\
\hline Orchidaceae & Rhynchostele & aptera & (Lex.) Soto Arenas et Salazar & & \\
\hline Orchidaceae & Rhynchostele & maculata & (Lex.) Soto Arenas et Salazar & & \\
\hline
\end{tabular}




\begin{tabular}{|c|c|c|c|c|c|}
\hline Family & Genus & Specific epithet & Species authors & $\begin{array}{l}\text { Infraspecific } \\
\text { rank and epithet }\end{array}$ & $\begin{array}{l}\text { Infraspecific } \\
\text { taxon Authors }\end{array}$ \\
\hline Orobanchaceae & Conopholis & alpina & Liebm. & & \\
\hline Oxalidaceae & Oxalis & alpina & (Rose) Rose ex R. Knuth & & \\
\hline Oxalidaceae & Oxalis & bipartita & A. St.-Hil. & & \\
\hline Oxalidaceae & Oxalis & discolor & Klotzsch & & \\
\hline Oxalidaceae & Oxalis & divergens & Benth. ex Lindl. & & \\
\hline Papaveraceae & Argemone & mexicana & L. & & \\
\hline Papaveraceae & Bocconia & arborea & S. Watson & & \\
\hline Passifloraceae & Turnera & diffusa & Willd. ex Schult. & & \\
\hline Passifloraceae & Turnera & ulmifolia & L. & & \\
\hline Pedaliaceae & Martynia & аппиа & L. & & \\
\hline Pedaliaceae & Proboscidea & fragrans & (Lindl.) Decne. & & \\
\hline Pedaliaceae & Proboscidea & louisianica & (Mill.) Thell. & & \\
\hline Phytolaccaceae & Phytolacca & icosandra & L. & & \\
\hline Phytolaccaceae & Rivina & humilis & L. & & \\
\hline Pinaceae & Pinus & herrerae & Martínez & & \\
\hline Pinaceae & Pinus & lawsonii & Roezl ex Gordon & & \\
\hline Pinaceae & Pinus & montezumae & Lamb. & & \\
\hline Pinaceae & Pinus & oоcarpa & Schiede & & \\
\hline Pinaceae & Pinus & pringlei & Shaw & & \\
\hline Pinaceae & Pinus & pseudostrobus & Lindl. & & \\
\hline Pinaceae & Pinus & pseudostrobus & Lindl. & var. apulcensis & (Lindl.) Shaw \\
\hline Pinaceae & Pinus & strobus & L. & & \\
\hline Pinaceae & Pinus & devoniana & Lindl. & & \\
\hline Piperaceae & Peperomia & campylotropa & A.W. Hill & & \\
\hline Piperaceae & Peperomia & umbilicata & Ruiz et Pav. & & \\
\hline Piperaceae & Peperomia & urocarpa & Fisch. et C.A. Mey. & & \\
\hline Piperaceae & Piper & amalago & L. & & \\
\hline Piperaceae & Piper & auritum & Kunth & & \\
\hline Piperaceae & Piper & sanctum & (Miq.) Schltdl. ex C.DC. & & \\
\hline Plantaginaceae & Plantago & australis & Lam. & & \\
\hline Plantaginaceae & Plantago & major & L. & & \\
\hline Plumbaginaceae & Plumbago & pulchella & Boiss. & & \\
\hline Plumbaginaceae & Plumbago & zeylanica & L. & & \\
\hline Poaceae & Aegopogon & cenchroides & Humb. et Bonpl. ex Willd. & & \\
\hline Poaceae & Aegopogon & tenellus & (DC.) Trin. & & \\
\hline Poaceae & Agrostis & ghiesbreghtii & E. Fourn. & & \\
\hline Poaceae & Andropogon & glomeratus & $\begin{array}{l}\text { (Walter) Britton, Sterns et } \\
\text { Poggenb. }\end{array}$ & & \\
\hline Poaceae & Anthephora & hermaphrodita & (L.) Kuntze & & \\
\hline Poaceae & Aristida & adscensionis & L. & & \\
\hline Poaceae & Aristida & curvifolia & E. Fourn. & & \\
\hline Poaceae & Aristida & divaricata & Humb. et Bonpl. ex Willd. & & \\
\hline Poaceae & Aristida & glauca & (Nees) Walp. & & \\
\hline Poaceae & Aristida & jorullensis & Kunth & & \\
\hline
\end{tabular}




\begin{tabular}{|c|c|c|c|c|c|}
\hline Family & Genus & Specific epithet & Species authors & $\begin{array}{l}\text { Infraspecific } \\
\text { rank and epithet }\end{array}$ & $\begin{array}{l}\text { Infraspecific } \\
\text { taxon Authors }\end{array}$ \\
\hline Poaceae & Aristida & schiedeana & Trin. et Rupr. & & \\
\hline Poaceae & Aristida & ternipes & Cav. & & \\
\hline Poaceae & Aristida & flaccida & Trin. et Rupr. & & \\
\hline Poaceae & Arundo & donax & Forssk. & & \\
\hline Poaceae & Avena & fatua & L. & & \\
\hline Poaceae & Avena & sativa & L. & & \\
\hline Poaceae & Bothriochloa & barbinodis & (Lag.) Herter & & \\
\hline Poaceae & Bothriochloa & laguroides & (DC.) Herter & & \\
\hline Poaceae & Bothriochloa & saccharoides & (Sw.) Rydb. & & \\
\hline Poaceae & Bothriochloa & springfieldii & (Gould) Parodi & & \\
\hline Poaceae & Bouteloua & aristidoides & (Kunth) Griseb. & & \\
\hline Poaceae & Bouteloua & barbata & Lag. & & \\
\hline Poaceae & Bouteloua & chondrosioides & (Kunth) Benth. ex S. Watson & & \\
\hline Poaceae & Bouteloua & curtipendula & (Michx.) Torr. & & \\
\hline Poaceae & Bouteloua & distans & Swallen & & \\
\hline Poaceae & Bouteloua & media & (E. Fourn.) Gould et Kapadia & & \\
\hline Poaceae & Bouteloua & pedicellata & Swallen & & \\
\hline Poaceae & Bouteloua & radicosa & (E. Fourn.) Griffiths & & \\
\hline Poaceae & Bouteloua & repens & (Kunth) Scribn. et Merr. & & \\
\hline Poaceae & Bouteloua & simplex & Lag. & & \\
\hline Poaceae & Bouteloua & triaena & (Trin.) Scribn. & & \\
\hline Poaceae & Bouteloua & uniflora & Vasey & & \\
\hline Poaceae & Bouteloua & aristidoides & (Kunth) Griseb. & & \\
\hline Poaceae & Brachiaria & fasciculata & (Sw.) Parodi & & \\
\hline Poaceae & Brachiaria & meziana & Hitchc. & & \\
\hline Poaceae & Brachiaria & mollis & (Sw.) Parodi & & \\
\hline Poaceae & Brachiaria & fasciculata & (Sw.) Parodi & & \\
\hline Poaceae & Brachypodium & mexicanum & (Roem. et Schult.) Link & & \\
\hline Poaceae & Briza & minor & L. & & \\
\hline Poaceae & Briza & subaristata & Lam. & & \\
\hline Poaceae & Bromus & anomalus & E. Fourn. & & \\
\hline Poaceae & Bromus & carinatus & Hook. et Arn. & & \\
\hline Poaceae & Bromus & exaltatus & Bernh. & & \\
\hline Poaceae & Buchloe & dactyloides & (Nutt.) Engelm. & & \\
\hline Poaceae & Cathestecum & brevifolium & Swallen & & \\
\hline Poaceae & Cathestecum & erectum & Vasey et Hack. & & \\
\hline Poaceae & Cathestecum & prostratum & J.Presl & & \\
\hline Poaceae & Cathestecum & varium & Swallen & & \\
\hline Poaceae & Cenchrus & ciliaris & L. & & \\
\hline Poaceae & Cenchrus & echinatus & L. & & \\
\hline Poaceae & Cenchrus & incertus & M.A. Curtis & & \\
\hline Poaceae & Cenchrus & multiflorus & J. Presl & & \\
\hline Poaceae & Cenchrus & myosuroides & Kunth & & \\
\hline Poaceae & Cenchrus & pilosus & Kunth & & \\
\hline
\end{tabular}




\begin{tabular}{|c|c|c|c|c|c|}
\hline Family & Genus & Specific epithet & Species authors & $\begin{array}{l}\text { Infraspecific } \\
\text { rank and epithet }\end{array}$ & $\begin{array}{l}\text { Infraspecific } \\
\text { taxon Authors }\end{array}$ \\
\hline Poaceae & Cenchrus & tribuloides & L. & & \\
\hline Poaceae & Chloris & ciliata & Sw. & & \\
\hline Poaceae & Chloris & radiata & (L.) Sw. & & \\
\hline Poaceae & Chloris & rufescens & Steud. & & \\
\hline Poaceae & Chloris & submutica & Kunth & & \\
\hline Poaceae & Chloris & virgata & Sw. & & \\
\hline Poaceae & Chloris & rufescens & Lag. & & \\
\hline Poaceae & Chondrosum & scorpioides & (Lag.) Kunth & & \\
\hline Poaceae & Chondrosum & simplex & (Lag.) Kunth & & \\
\hline Poaceae & Chondrosum & hirsutum & (Lag.) Sweet & & \\
\hline Poaceae & Cottea & pappophoroides & Kunth & & \\
\hline Poaceae & Cymbopogon & citratus & (DC.) Stapf & & \\
\hline Poaceae & Cynodon & dactylon & (L.) Pers. & & \\
\hline Poaceae & Dactyloctenium & aegypticum & (L.) Willd. & & \\
\hline Poaceae & Deschampsia & liebmanniana & (E. Fourn.) Hitchc. & & \\
\hline Poaceae & Digitaria & bicornis & (Lam.) Roem. et Schult. & & \\
\hline Poaceae & Digitaria & californica & (Benth.) Henrard & & \\
\hline Poaceae & Digitaria & ciliaris & (Retz.) Koeler & & \\
\hline Poaceae & Digitaria & insularis & (L.) Mez ex Ekman & & \\
\hline Poaceae & Digitaria & leucitis & (Trin.) Henrard & & \\
\hline Poaceae & Distichlis & spicata & (L.) Greene & & \\
\hline Poaceae & Echinochloa & colona & (L.) Link & & \\
\hline Poaceae & Echinochloa & crus-galli & (L.) P. Beauv. & & \\
\hline Poaceae & Echinochloa & oplismenoides & (E. Fourn.) Hitchc. & & \\
\hline Poaceae & Eleusine & multiflora & Hochst. ex A. Rich. & & \\
\hline Poaceae & Elionurus & tripsacoides & Willd. & & \\
\hline Poaceae & Elymus & longifolius & (J.G. Sm.) Gould & & \\
\hline Poaceae & Elymus & repens & (L.) Gould & & \\
\hline Poaceae & Enneapogon & desvauxii & P. Beauv. & & \\
\hline Poaceae & Enteropogon & chlorideus & (J. Presl) Clayton & & \\
\hline Poaceae & Eragrostis & atrovirens & Lange & & \\
\hline Poaceae & Eragrostis & barrelieri & Daveau & & \\
\hline Poaceae & Eragrostis & cilianensis & (All.) Janch. & & \\
\hline Poaceae & Eragrostis & ciliaris & (L.) R. Br. & & \\
\hline Poaceae & Eragrostis & intermedia & Hitchc. & & \\
\hline Poaceae & Eragrostis & lugens & Nees & & \\
\hline Poaceae & Eragrostis & maypurensis & (Kunth) Steud. & & \\
\hline Poaceae & Eragrostis & mexicana & (Hornem.) Link & & \\
\hline Poaceae & Eragrostis & pectinacea & (Michx.) Nees & & \\
\hline Poaceae & Eragrostis & pilosa & (L.) P. Beauv. & & \\
\hline Poaceae & Eragrostis & swallenii & Hitchc. & & \\
\hline Poaceae & Eragrostis & tephrosanthos & Roem. et Schult. & & \\
\hline Poaceae & Eriochloa & nelsonii & Scribn. et J.G. Sm. & & \\
\hline
\end{tabular}




\begin{tabular}{|c|c|c|c|c|c|}
\hline Family & Genus & Specific epithet & Species authors & $\begin{array}{l}\text { Infraspecific } \\
\text { rank and epithet }\end{array}$ & $\begin{array}{l}\text { Infraspecific } \\
\text { taxon Authors }\end{array}$ \\
\hline Poaceae & Erioneuron & avenaceum & $\begin{array}{l}\text { (Humb., Bonpl. et Kunth) } \\
\text { Tateoka }\end{array}$ & & \\
\hline Poaceae & Erioneuron & avenaceum & $\begin{array}{l}\text { (Humb., Bonpl. et Kunth) } \\
\text { Tateoka }\end{array}$ & $\begin{array}{l}\text { var. } \\
\text { grandiflorum }\end{array}$ & (Vasey) Gould \\
\hline Poaceae & Festuca & amplissima & Rupr. ex Galeotti & & \\
\hline Poaceae & Festuca & callosa & (Piper) St.-Yves & & \\
\hline Poaceae & Festuca & lugens & $\begin{array}{l}\text { (E. Fourn.) Hitchc. ex Hern.- } \\
\text { Xol. }\end{array}$ & & \\
\hline Poaceae & Griffithsochloa & multifida & (Griffiths) G.J. Pierce & & \\
\hline Poaceae & Heteropogon & contortus & $\begin{array}{l}\text { (L.) P. Beauv. ex Roem. et } \\
\text { Schult. }\end{array}$ & & \\
\hline Poaceae & Hilaria & cenchroides & Kunth & & \\
\hline Poaceae & Hordeum & vulgare & L. & & \\
\hline Poaceae & Ichnanthus & pallens & (Sw.) Munro ex Benth. & & \\
\hline Poaceae & Lasiacis & divaricata & (L.) Hitchc. & & \\
\hline Poaceae & Lasiacis & nigra & Davidse & & \\
\hline Poaceae & Lasiacis & ruscifolia & (Kunth) Hitchc. ex Chase & & \\
\hline Poaceae & Leersia & hexandra & Sw. & & \\
\hline Poaceae & Leptochloa & dubia & (Kunth) Nees & & \\
\hline Poaceae & Leptochloa & fusca & (L.) Kunth & subsp. uninervia & $\begin{array}{l}\text { (J. Presl) } \\
\text { N.Snow }\end{array}$ \\
\hline Poaceae & Leptochloa & panicoides & (J. Presl) Hitchc. & & \\
\hline Poaceae & Leptochloa & mucronata & (Michx.) Kunth & & \\
\hline Poaceae & Lolium & perenne & L. & & \\
\hline Poaceae & Lycurus & phleoides & Kunth & & \\
\hline Poaceae & Melinis & repens & (Willd.) Zizka & & \\
\hline Poaceae & Metcalfia & mexicana & (Scribn.) Conert & & \\
\hline Poaceae & Microchloa & kunthii & Desv. & & \\
\hline Poaceae & Muhlenbergia & ciliata & (Kunth) Kunth & & \\
\hline Poaceae & Muhlenbergia & depauperata & Scribn. & & \\
\hline Poaceae & Muhlenbergia & distans & Swallen & & \\
\hline Poaceae & Muhlenbergia & distichophylla & (J. Presl) Kunth & & \\
\hline Poaceae & Muhlenbergia & emersleyi & Vasey & & \\
\hline Poaceae & Muhlenbergia & gigantea & (E. Fourn.) Hitchc. & & \\
\hline Poaceae & Muhlenbergia & implicata & (Kunth) Trin. & & \\
\hline Poaceae & Muhlenbergia & longiligula & Hitchc. & & \\
\hline Poaceae & Muhlenbergia & macroura & $\begin{array}{l}\text { (Humb., Bonpl. et Kunth) } \\
\text { Hitchc. }\end{array}$ & & \\
\hline Poaceae & Muhlenbergia & microsperma & (DC.) Trin. & & \\
\hline Poaceae & Muhlenbergia & montana & (Nutt.) Hitchc & & \\
\hline Poaceae & Muhlenbergia & pubescens & $\begin{array}{l}\text { (Humb., Bonpl. et Kunth) } \\
\text { Hitchc. }\end{array}$ & & \\
\hline Poaceae & Muhlenbergia & repens & (J. Presl) Hitchc. & & \\
\hline Poaceae & Muhlenbergia & rigida & (Kunth) Kunth & & \\
\hline Poaceae & Muhlenbergia & robusta & (E. Fourn.) Hitchc. & & \\
\hline
\end{tabular}




\begin{tabular}{|c|c|c|c|c|c|}
\hline Family & Genus & Specific epithet & Species authors & $\begin{array}{l}\text { Infraspecific } \\
\text { rank and epithet }\end{array}$ & $\begin{array}{l}\text { Infraspecific } \\
\text { taxon Authors }\end{array}$ \\
\hline Poaceae & Muhlenbergia & spiciformis & Trin. & & \\
\hline Poaceae & Muhlenbergia & tenella & (Kunth) Trin. & & \\
\hline Poaceae & Muhlenbergia & tenuifolia & (Kunth) Kunth & & \\
\hline Poaceae & Muhlenbergia & vaginata & Swallen & & \\
\hline Poaceae & Muhlenbergia & versicolor & Swallen & & \\
\hline Poaceae & Muhlenbergia & dubia & E. Fourn. & & \\
\hline Poaceae & Nassella & lepida & (Hitchc.) Barkworth & & \\
\hline Poaceae & Nassella & linearifolia & (E. Fourn.) R.W. Pohl & & \\
\hline Poaceae & Nassella & mucronata & (Kunth) R.W. Pohl & & \\
\hline Poaceae & Nassella & tenuissima & (Trin.) Barkworth & & \\
\hline Poaceae & Opizia & stolonifera & J. Presl & & \\
\hline Poaceae & Oplismenus & burmannii & (Retz.) P. Beauv. & & \\
\hline Poaceae & Oplismenus & compositus & (L.) P. Beauv. & & \\
\hline Poaceae & Otatea & acuminata & $\begin{array}{l}\text { (Munro) C.E. Calderón ex } \\
\text { Soderstr. }\end{array}$ & & \\
\hline Poaceae & Panicum & bulbosum & Kunth & & \\
\hline Poaceae & Panicum & decolorans & Kunth & & \\
\hline Poaceae & Panicum & ghiesbreghtii & E. Fourn. & & \\
\hline Poaceae & Panicum & hallii & Vasey & & \\
\hline Poaceae & Panicum & hirticaule & J. Presl & & \\
\hline Poaceae & Panicum & laxiflorum & Lam. & & \\
\hline Poaceae & Panicum & maximum & Jacq. & & \\
\hline Poaceae & Panicum & obtusum & Kunth & & \\
\hline Poaceae & Panicum & virgatum & L. & & \\
\hline Poaceae & Pappophorum & pappiferum & (Lam.) Kuntze & & \\
\hline Poaceae & Paspalum & botterii & (E. Fourn.) Chase & & \\
\hline Poaceae & Paspalum & conjugatum & P.J. Bergius & & \\
\hline Poaceae & Paspalum & distichum & L. & & \\
\hline Poaceae & Paspalum & humboldtianum & Flüggé & & \\
\hline Poaceae & Paspalum & langei & (E. Fourn.) Nash & & \\
\hline Poaceae & Paspalum & notatum & Flüggé & & \\
\hline Poaceae & Paspalum & pubiflorum & E. Fourn. & & \\
\hline Poaceae & Paspalum & denticulatum & Trin. & & \\
\hline Poaceae & Pennisetum & crinitum & (Kunth) Spreng. & & \\
\hline Poaceae & Pennisetum & distachyum & (E. Fourn.) Rupr. ex Chase & & \\
\hline Poaceae & Phalaris & canariensis & L. & & \\
\hline Poaceae & Piptochaetium & angustifolium & (Hitchc.) Valencia et Costas & & \\
\hline Poaceae & Piptochaetium & fimbriatum & $\begin{array}{l}\text { (Humb., Bonpl. et Kunth) } \\
\text { Hitchc. }\end{array}$ & & \\
\hline Poaceae & Piptochaetium & virescens & $\begin{array}{l}\text { (Humb., Bonpl. et Kunth) } \\
\text { Parodi }\end{array}$ & & \\
\hline Poaceae & Poa & аппиа & L. & & \\
\hline Poaceae & Polypogon & interruptus & Kunth & & \\
\hline Poaceae & Polypogon & viridis & (Gouan) Breistr. & & \\
\hline Poaceae & Pringleochloa & stolonifera & (E. Fourn.) Scribn. & & \\
\hline
\end{tabular}




\begin{tabular}{|c|c|c|c|c|c|}
\hline Family & Genus & Specific epithet & Species authors & $\begin{array}{l}\text { Infraspecific } \\
\text { rank and epithet }\end{array}$ & $\begin{array}{l}\text { Infraspecific } \\
\text { taxon Authors }\end{array}$ \\
\hline Poaceae & Saccharum & officinarum & L. & & \\
\hline Poaceae & Schizachyrium & sanguineum & (Retz.) Alston & & \\
\hline Poaceae & Schizachyrium & tenerum & Nees & & \\
\hline Poaceae & Setaria & italica & (L.) P. Beauv. & & \\
\hline Poaceae & Setaria & leucopila & (Scribn. et Merr.) K. Schum. & & \\
\hline Poaceae & Setaria & liebmannii & E. Fourn. & & \\
\hline Poaceae & Setaria & macrostachya & Kunth & & \\
\hline Poaceae & Setaria & parviflora & (Poir.) M. Kerguelen & & \\
\hline Poaceae & Setaria & tenax & Rich.) Desv. & & \\
\hline Poaceae & Setaria & viridis & (L.) P. Beauv. & & \\
\hline Poaceae & Setaria & grisebachii & E. Fourn. & & \\
\hline Poaceae & Setaria & verticillata & (L.) P. Beauv. & & \\
\hline Poaceae & Setariopsis & latiglumis & (Vasey) Scribn. & & \\
\hline Poaceae & Sorghastrum & nutans & (L.) Nash & & \\
\hline Poaceae & Sorghum & bicolor & (L.) Moench & & \\
\hline Poaceae & Sorghum & halepense & (L.) Pers. & & \\
\hline Poaceae & Sporobolus & airoides & (Torr.) Torr. & & \\
\hline Poaceae & Sporobolus & atrovirens & (Kunth) Kunth & & \\
\hline Poaceae & Sporobolus & buckleyi & Vasey & & \\
\hline Poaceae & Sporobolus & indicus & (L.) R. Br. & & \\
\hline Poaceae & Sporobolus & pyramidalis & P. Beauv. & & \\
\hline Poaceae & Sporobolus & pyramidatus & (Lam.) C.L. Hitchc. & & \\
\hline Poaceae & Sporobolus & trichodes & Hitchc. & & \\
\hline Poaceae & Stipa & constricta & Hitchc. & & \\
\hline Poaceae & Stipa & editorum & E. Fourn. & & \\
\hline Poaceae & Stipa & eminens & Cav. & & \\
\hline Poaceae & Stipa & $i c h u$ & (Ruiz et Pav.) Kunth & & \\
\hline Poaceae & Trachypogon & spicatus & (L.f.) Kuntze & & \\
\hline Poaceae & Tragus & berteronianus & Schult. & & \\
\hline Poaceae & Trichloris & pluriflora & E. Fourn. & & \\
\hline Poaceae & Tripsacum & dactyloides & (L.) L. & & \\
\hline Poaceae & Tripsacum & zopilotense & Hern.-Xol. et Randolph & & \\
\hline Poaceae & Trisetum & irazuense & (Kuntze) Hitchc. & & \\
\hline Poaceae & Triticum & aestivum & L. & & \\
\hline Poaceae & Zea & mays & L. & & \\
\hline Poaceae & Zeugites & americana & Willd. & & \\
\hline Polemoniaceae & Loeselia & coerulea & (Cav.) G. Don & & \\
\hline Polemoniaceae & Loeselia & glandulosa & (Cav.) G. Don & & \\
\hline Polemoniaceae & Loeselia & purpusii & Brandegee & & \\
\hline Polemoniaceae & Polemonium & caeruleum & L. & & \\
\hline Polygalaceae & Polygala & cuspidulata & S.F. Blake & & \\
\hline Polygalaceae & Polygala & scoparia & Kunth & & \\
\hline Polygonaceae & Antigonon & leptopus & Hook. et Arn. & & \\
\hline Polygonaceae & Polygonum & hydropiperoides & Michx. & & \\
\hline
\end{tabular}




\begin{tabular}{|c|c|c|c|c|c|}
\hline Family & Genus & Specific epithet & Species authors & $\begin{array}{l}\text { Infraspecific } \\
\text { rank and epithet }\end{array}$ & $\begin{array}{l}\text { Infraspecific } \\
\text { taxon Authors }\end{array}$ \\
\hline Polygonaceae & Polygonum & lapathifolium & L. & & \\
\hline Polygonaceae & Rumex & acetosella & L. & & \\
\hline Polygonaceae & Rumex & crispus & L. & & \\
\hline Polygonaceae & Ruprechtia & fusca & Fernald & & \\
\hline Portulacaceae & Portulaca & grandiflora & Hook. & & \\
\hline Portulacaceae & Portulaca & oleracea & L. & & \\
\hline Portulacaceae & Portulaca & pilosa & L. & & \\
\hline Portulacaceae & Talinum & paniculatum & Ruiz et Pav. & & \\
\hline Primulaceae & Anagallis & arvensis & L. & & \\
\hline Primulaceae & Myrsine & juergensenii & (Mez) Ricketson et Pipoly & & \\
\hline Ranunculaceae & Anemone & mexicana & Kunth & & \\
\hline Ranunculaceae & Ranunculus & petiolaris & $\begin{array}{l}\text { Humb., Bonpl. et Kunth ex } \\
\text { DC. }\end{array}$ & & \\
\hline Ranunculaceae & Thalictrum & gibbosum & Lecoy. & & \\
\hline Rhamnaceae & Ceanothus & greggii & A. Gray & & \\
\hline Rhamnaceae & Karwinskia & mollis & Schltdl. & & \\
\hline Rhamnaceae & Rhamnus & humboldtiana & Willd. ex Schult. & & \\
\hline Rhamnaceae & Ziziphus & amole & (Sessé et Moc.) M.C. Johnst. & & \\
\hline Rhamnaceae & Ziziphus & pedunculata & (Brandegee) Standl. & & \\
\hline Rosaceae & Crataegus & mexicana & D. Don & & \\
\hline Rosaceae & Crataegus & orientalis & Pall. ex M. Bieb. & subsp. presliana & K.I.Chr. \\
\hline Rosaceae & Malacomeles & denticulata & (Kunth) G.N. Jones & & \\
\hline Rosaceae & Prunus & dulcis & (Mill.) D.A. Webb & & \\
\hline Rosaceae & Prunus & armeniaca & L. & & \\
\hline Rosaceae & Prunus & persica & (L.) Stokes & & \\
\hline Rosaceae & Prunus & virginiana & L. & & \\
\hline Rosaceae & Rosa & centifolia & Lour. & & \\
\hline Rosaceae & Rosa & gallica & L. & & \\
\hline Rosaceae & Rubus & adenotrichus & Schltdl. & & \\
\hline Rosaceae & Rubus & liebmannii & Focke & & \\
\hline Rubiaceae & Bouvardia & longiflora & (Cav.) Kunth & & \\
\hline Rubiaceae & Bouvardia & ternifolia & (Cav.) Schltdl. & & \\
\hline Rubiaceae & Chiococca & alba & (L.) Hitchc. & & \\
\hline Rubiaceae & Crusea & diversifolia & (Kunth) W.R. Anderson & & \\
\hline Rubiaceae & Galium & fuscum & M. Martens et Galeotti & & \\
\hline Rubiaceae & Galium & mexicanum & Kunth & & \\
\hline Rubiaceae & Galium & triflorum & Michx. & & \\
\hline Rubiaceae & Randia & capitata & DC. & & \\
\hline Rubiaceae & Richardia & scabra & L. & & \\
\hline Rutaceae & Casimiroa & edulis & La Llave & & \\
\hline Rutaceae & Esenbeckia & macrantha & Rose & & \\
\hline Rutaceae & Ptelea & trifoliata & L. & & \\
\hline Rutaceae & Ruta & chalepensis & L. & & \\
\hline Salicaceae & Populus & alba & L. & & \\
\hline
\end{tabular}




\begin{tabular}{|c|c|c|c|c|c|}
\hline Family & Genus & Specific epithet & Species authors & $\begin{array}{l}\text { Infraspecific } \\
\text { rank and epithet }\end{array}$ & $\begin{array}{l}\text { Infraspecific } \\
\text { taxon Authors }\end{array}$ \\
\hline Salicaceae & Salix & bonplandiana & Kunth & & \\
\hline Salicaceae & Salix & humboldtiana & Willd. & & \\
\hline Salicaceae & Salix & nigra & Marshall & & \\
\hline Sapindaceae & Cardiospermum & halicacabum & L. & & \\
\hline Sapindaceae & Dodonaea & viscosa & (L.) Jacq. & & \\
\hline Sapindaceae & Sapindus & saponaria & L. & & \\
\hline Saxifragaceae & Pterostemon & rotundifolius & Ramírez & & \\
\hline Scrophulariaceae & Bacopa & monnieri & (L.) Wettst. & & \\
\hline Scrophulariaceae & Berendtiella & levigata & $\begin{array}{l}\text { (B.L. Rob. et Greenm.) } \\
\text { Thieret }\end{array}$ & & \\
\hline Scrophulariaceae & Buddleja & cordata & Kunth & & \\
\hline Scrophulariaceae & Buddleja & parviflora & Kunth & & \\
\hline Scrophulariaceae & Capraria & biflora & L. & & \\
\hline Scrophulariaceae & Castilleja & arvensis & Schltdl. et Cham. & & \\
\hline Scrophulariaceae & Lamourouxia & dasyantha & (Cham. et Schltdl.) W.R. Ernst & & \\
\hline Scrophulariaceae & Lamourouxia & nelsonii & B.L. Rob. et Greenm. & & \\
\hline Scrophulariaceae & Lamourouxia & viscosa & Kunth & & \\
\hline Scrophulariaceae & Penstemon & barbatus & (Cav.) Roth & & \\
\hline Scrophulariaceae & Penstemon & campanulatus & Cav.) Willd. & & \\
\hline Scrophulariaceae & Russelia & obtusata & S.F. Blake & & \\
\hline Scrophulariaceae & Schistophragma & pusillum & Benth. & & \\
\hline Scrophulariaceae & Veronica & polita & Fr. & & \\
\hline Simaroubaceae & Castela & tortuosa & Liebm. & & \\
\hline Solanaceae & Datura & discolor & Bernh. & & \\
\hline Solanaceae & Brugmansia & suaveolens & $\begin{array}{l}\text { (Humb. et Bonpl. ex Willd.) } \\
\text { Bercht. et J. Presl }\end{array}$ & & \\
\hline Solanaceae & Capsicum & аппиит & L. & & \\
\hline Solanaceae & Cestrum & nocturnum & L. & & \\
\hline Solanaceae & Datura & $\times$ candida & $\begin{array}{l}\text { (Pers.) } \\
\text { Saff. }\end{array}$ & & \\
\hline Solanaceae & Datura & innoxia & Mill. & & \\
\hline Solanaceae & Datura & stramonium & L. & & \\
\hline Solanaceae & Jaltomata & procumbens & (Cav.) J.L. Gentry & & \\
\hline Solanaceae & Lycianthes & acapulcensis & (Baill.) D'Arcy & & \\
\hline Solanaceae & Lycopersicon & esculentum & Mill. & & \\
\hline Solanaceae & Margaranthus & solanaceous & Schltdl. & & \\
\hline Solanaceae & Nicotiana & glauca & Graham & & \\
\hline Solanaceae & Nicotiana & tabacum & L. & & \\
\hline Solanaceae & Petunia & hybrida & Vilm. & & \\
\hline Solanaceae & Physalis & foetens & Poir. & & \\
\hline Solanaceae & Physalis & nicandroides & Schltdl. & & \\
\hline Solanaceae & Physalis & philadelphica & Lam. & & \\
\hline Solanaceae & Solandra & grandiflora & Sw. & & \\
\hline Solanaceae & Solandra & maxima & $\begin{array}{l}\text { (Moc. et Sessé ex Dunal) P.S. } \\
\text { Green }\end{array}$ & & \\
\hline
\end{tabular}




\begin{tabular}{|c|c|c|c|c|c|}
\hline Family & Genus & Specific epithet & Species authors & $\begin{array}{l}\text { Infraspecific } \\
\text { rank and epithet }\end{array}$ & $\begin{array}{l}\text { Infraspecific } \\
\text { taxon Authors }\end{array}$ \\
\hline Solanaceae & Solanum & adscendens & Sendtn. & & \\
\hline Solanaceae & Solanum & agrimoniifolium & Rydb. & & \\
\hline Solanaceae & Solanum & americanum & Mill. & & \\
\hline Solanaceae & Solanum & bulbocastanum & Dunal & & \\
\hline Solanaceae & Solanum & dulcamaroides & Dunal & & \\
\hline Solanaceae & Solanum & lanceolatum & Cav. & & \\
\hline Solanaceae & Solanum & nigrescens & M. Martens et Galeotti & & \\
\hline Solanaceae & Solanum & rostratum & Dunal & & \\
\hline Solanaceae & Solanum & tridynamum & Dunal & & \\
\hline Solanaceae & Solanum & verbascifolium & L. & & \\
\hline Solanaceae & Solanum & asperolanatum & Ruiz et Pav. & & \\
\hline Solanaceae & Solanum & erianthum & D. Don & & \\
\hline Solanaceae & Solanum & nigricans & M. Martens et Galeotti & & \\
\hline Styracaceae & Styrax & argenteus & C. Presl & & \\
\hline Taxodiaceae & Taxodium & huegelii & C. Lawso & & \\
\hline Tropaeolaceae & Tropaeolum & majus & L. & & \\
\hline Typhaceae & Typha & domingensis & Pers. & & \\
\hline Ulmaceae & Celtis & caudata & Planch. & & \\
\hline Ulmaceae & Celtis & pallida & Torr. & & \\
\hline Ulmaceae & Trema & micrantha & (L.) Blume & & \\
\hline Urticaceae & Boehmeria & macrophylla & Hornem. & & \\
\hline Urticaceae & Parietaria & debilis & G. Forst. & & \\
\hline Urticaceae & Phenax & mexicanus & Wedd. & & \\
\hline Urticaceae & Pilea & trianthemoides & (Sw.) Lindl. & & \\
\hline Verbenaceae & Bouchea & prismatica & (L.) Kuntze & & \\
\hline Verbenaceae & Glandularia & elegans & (Kunth) Umber & & \\
\hline Verbenaceae & Glandularia & corymbosa & $\begin{array}{l}\text { (Ruiz et Pav.) N. O'Leary et } \\
\text { P. Peralta }\end{array}$ & & \\
\hline Verbenaceae & Lantana & achyranthifolia & Desf. & & \\
\hline Verbenaceae & Lantana & camara & L. & & \\
\hline Verbenaceae & Lantana & involucrata & L. & & \\
\hline Verbenaceae & Lantana & urticoides & Hayek & & \\
\hline Verbenaceae & Lantana & velutina & M. Martens et Galeotti & & \\
\hline Verbenaceae & Lantana & horrida & Kunth & & \\
\hline Verbenaceae & Lippia & oaxacana & B.L. Rob. et Greenm. & & \\
\hline Verbenaceae & Lippia & graveolens & Kunth & & \\
\hline Verbenaceae & Phyla & scaberrima & (Juss. ex Pers.) Moldenke & & \\
\hline Verbenaceae & Vitex & mollis & Kunth & & \\
\hline Violaceae & Hybanthus & attenuatus & $\begin{array}{l}\text { (Humb. et Bonpl. ex Schult.) } \\
\text { Schulze-Menz }\end{array}$ & & \\
\hline Vitaceae & Cissus & tiliacea & Kunth & & \\
\hline Vitaceae & Vitis & vinifera & L. & & \\
\hline Xanthorrhoeaceae & Aloe & vera & (L.) Burm.f. & & \\
\hline Xanthorrhoeaceae & Asphodelus & fistulosus & L. & & \\
\hline
\end{tabular}




\begin{tabular}{|c|c|c|c|c|c|}
\hline Family & Genus & Specific epithet & Species authors & $\begin{array}{l}\text { Infraspecific } \\
\text { rank and epithet }\end{array}$ & $\begin{array}{l}\text { Infraspecific } \\
\text { taxon Authors }\end{array}$ \\
\hline Zamiaceae & Dioon & caputoi & $\begin{array}{l}\text { De Luca, Sabato et Vázq. } \\
\text { Torres }\end{array}$ & & \\
\hline Zamiaceae & Dioon & rzedowskii & De Luca et al. & & \\
\hline Zygophyllaceae & Kallstroemia & hirsutissima & Vail & & \\
\hline Zygophyllaceae & Kallstroemia & intermedia & Rydb. & & \\
\hline Zygophyllaceae & Morkillia & mexicana & (DC.) Rose et Painter & & \\
\hline
\end{tabular}

\section{Appendix 2: Seed germination experiments carried out at the Fes-I UNAM Seed Bank (Fes-I) and at the RBG Kew's Millennium Seed Bank (MSB)}

\begin{tabular}{|c|c|c|c|c|c|c|c|c|}
\hline Family & Taxon & $\begin{array}{l}\text { Seed- } \\
\text { bank }\end{array}$ & $\begin{array}{l}\text { Filled } \\
\text { seeds } \\
(\%)\end{array}$ & Pretreatment & $\begin{array}{l}\text { Temperature } \\
\left({ }^{\circ} \mathrm{C}\right)\end{array}$ & $\begin{array}{l}\text { Photo- } \\
\text { period } \\
(\mathrm{L} / \mathrm{D} ; \mathrm{h})\end{array}$ & $\begin{array}{l}\text { Germination } \\
(\%)\end{array}$ & $\begin{array}{l}\text { Dormancy } \\
\text { Index } \\
\text { (DI) }\end{array}$ \\
\hline Acanthaceae & $\begin{array}{l}\text { Gypsacanthus } \\
\text { nelsonii E.J. Lott, } \\
\text { V. Jaram. et Rzed. }\end{array}$ & Fes-I & & & 30 & $12 / 12$ & 58.9 & 0.4 \\
\hline Achatocarpaceae & $\begin{array}{l}\text { Phaulothamnus } \\
\text { spinescens A. } \\
\text { Gray }\end{array}$ & Fes-I & & & 30 & $12 / 12$ & 46.0 & 0.5 \\
\hline \multirow[t]{2}{*}{ Amaranthaceae } & $\begin{array}{l}\text { Chenopodium } \\
\text { murale L. }\end{array}$ & Fes-I & & & 30 & $12 / 12$ & 85.0 & 0.2 \\
\hline & & MSB & 100 & & 25 & $8 / 16$ & 75 & 0.25 \\
\hline Amaranthaceae & $\begin{array}{l}\text { Gomphrena serrata } \\
\text { L. }\end{array}$ & MSB & 14 & & & & & \\
\hline Amaranthaceae & $\begin{array}{l}\text { Iresine discolor } \\
\text { Greenm. }\end{array}$ & Fes-I & & & 30 & $12 / 12$ & 96.9 & 0.0 \\
\hline \multirow[t]{2}{*}{ Anacardiaceae } & $\begin{array}{l}\text { Actinocheita filicina } \\
\text { (Turckz.) Bullock }\end{array}$ & Fes-I & & & 30 & $12 / 12$ & 17.9 & 0.6 \\
\hline & & MSB & 85 & $\begin{array}{l}\text { Chipped with } \\
\text { scalpel }\end{array}$ & 25 & $8 / 16$ & 50 & 0.5 \\
\hline \multirow[t]{2}{*}{ Anacardiaceae } & $\begin{array}{l}\text { Amphipterygium } \\
\text { adstringens } \\
\text { (Schltdl.) Standl. }\end{array}$ & Fes-I & & & 30 & $12 / 12$ & 100.0 & 0.33 \\
\hline & & MSB & 27 & $\begin{array}{l}\text { Covering structure } \\
\text { partially removed }\end{array}$ & $35 / 20$ & $8 / 16$ & 67 & \\
\hline \multirow[t]{2}{*}{ Anacardiaceae } & $\begin{array}{l}\text { Cyrtocarpa procera } \\
\text { Kunth }\end{array}$ & Fes-I & & & 30 & $12 / 12$ & 50.0 & 0.5 \\
\hline & & MSB & 90 & $\begin{array}{l}\text { Scarify with mini } \\
\text { saw }\end{array}$ & 20 & $8 / 16$ & 90 & 0.1 \\
\hline Apocynaceae & $\begin{array}{l}\text { Matelea } \\
\text { trachyantha } \\
\text { (Greenm.) W.D. } \\
\text { Stevens }\end{array}$ & Fes-I & & & 30 & $12 / 12$ & 94.0 & 0.1 \\
\hline
\end{tabular}




\begin{tabular}{|c|c|c|c|c|c|c|c|c|}
\hline Family & Taxon & $\begin{array}{l}\text { Seed- } \\
\text { bank }\end{array}$ & $\begin{array}{l}\text { Filled } \\
\text { seeds } \\
(\%)\end{array}$ & Pretreatment & $\begin{array}{l}\text { Temperature } \\
\left({ }^{\circ} \mathrm{C}\right)\end{array}$ & $\begin{array}{l}\text { Photo- } \\
\text { period } \\
(\mathrm{L} / \mathrm{D} ; \mathrm{h})\end{array}$ & $\begin{array}{l}\text { Germination } \\
(\%)\end{array}$ & $\begin{array}{l}\text { Dormancy } \\
\text { Index } \\
\text { (DI) }\end{array}$ \\
\hline \multirow[t]{2}{*}{ Apocynaceae } & $\begin{array}{l}\text { Vallesia glabra } \\
\text { (Cav.) Link }\end{array}$ & Fes-I & & & 30 & $12 / 12$ & 43.3 & 0.5 \\
\hline & & MSB & 95 & & 25 & $8 / 16$ & 95 & 0.05 \\
\hline Asparagaceae & $\begin{array}{l}\text { Agave karwinskii } \\
\text { Zucc. }\end{array}$ & Fes-I & & & 30 & $12 / 12$ & 27.3 & 0.7 \\
\hline Asparagaceae & $\begin{array}{l}\text { Agave kerchovei } \\
\text { Lem. }\end{array}$ & Fes-I & & & 30 & $12 / 12$ & 82.2 & 0.2 \\
\hline \multirow[t]{2}{*}{ Asparagaceae } & $\begin{array}{l}\text { Agave } \\
\text { macroacantha } \\
\text { Zucc. }\end{array}$ & Fes-I & & & 30 & $12 / 12$ & 79.2 & 0.2 \\
\hline & & MSB & 85 & & 20 & $8 / 16$ & 62 & 0.38 \\
\hline Bignoniaceae & $\begin{array}{l}\text { Astianthus viminalis } \\
\text { (Kunth) Baill. }\end{array}$ & MSB & 100 & & 25 & $8 / 16$ & 55 & 0.45 \\
\hline \multirow[t]{2}{*}{ Bignoniaceae } & $\begin{array}{l}\text { Tecoma stans (L.) } \\
\text { Juss. ex Kunth }\end{array}$ & Fes-I & & & 30 & $12 / 12$ & 68.3 & 0.0 \\
\hline & & MSB & 30 & & 20 & $8 / 16$ & 38 & 0.62 \\
\hline \multirow[t]{2}{*}{ Boraginaceae } & $\begin{array}{l}\text { Cordia bullata (L.) } \\
\text { Roem. et Schult. } \\
\text { var. globosa (Jacq.) } \\
\text { Govaerts }\end{array}$ & Fes-I & & & 30 & $12 / 12$ & 23.1 & 0.8 \\
\hline & & MSB & 60 & & & & & \\
\hline \multirow[t]{2}{*}{ Boraginaceae } & $\begin{array}{l}\text { Cordia curassavica } \\
\text { (Jacq.) Roem. et } \\
\text { Schult. }\end{array}$ & Fes-I & & & 30 & $12 / 12$ & 6.4 & 0.9 \\
\hline & & MSB & 77 & $\begin{array}{l}\text { Covering structure } \\
\text { partially removed }\end{array}$ & 25 & $8 / 16$ & 100 & 0 \\
\hline \multirow[t]{2}{*}{ Bromeliaceae } & $\begin{array}{l}\text { Hechtia podantha } \\
\quad \mathrm{Mez}\end{array}$ & Fes-I & & & 30 & $12 / 12$ & 100.0 & 0.0 \\
\hline & & MSB & 54 & & 25 & $8 / 16$ & 100 & 0 \\
\hline Bromeliaceae & $\begin{array}{l}\text { Hechtia roseana } \\
\text { L.B.Sm. }\end{array}$ & Fes-I & & & 30 & $12 / 12$ & 13.3 & 0.9 \\
\hline \multirow[t]{2}{*}{ Burseraceae } & $\begin{array}{l}\text { Bursera aptera } \\
\text { Ramirez }\end{array}$ & Fes-I & & & 30 & $12 / 12$ & 0.0 & 1.0 \\
\hline & & MSB & 65 & & & & & \\
\hline \multirow[t]{2}{*}{ Burseraceae } & $\begin{array}{l}\text { Bursera fagaroides } \\
\text { (Kunth) Engl. }\end{array}$ & Fes-I & & & 30 & $12 / 12$ & 100.0 & 0.0 \\
\hline & & MSB & 50 & & & & & \\
\hline Burseraceae & $\begin{array}{l}\text { Bursera morelensis } \\
\text { Ramirez }\end{array}$ & MSB & 45 & & & & & \\
\hline \multirow[t]{2}{*}{ Burseraceae } & $\begin{array}{l}\text { Bursera } \\
\text { submoniliformis } \\
\text { Engl. }\end{array}$ & Fes-I & & & 30 & $12 / 12$ & 15.4 & 0.8 \\
\hline & & MSB & 30 & $\begin{array}{l}\text { Remove flesh from } \\
\text { fruit }\end{array}$ & 20 & $8 / 16$ & 17 & 0.83 \\
\hline Cactaceae & $\begin{array}{l}\text { Escontria chiotilla } \\
\text { (F.A.C. Weber) } \\
\text { Rose }\end{array}$ & Fes-I & & & 30 & $12 / 12$ & 96.7 & 0.0 \\
\hline
\end{tabular}




\begin{tabular}{|c|c|c|c|c|c|c|c|c|}
\hline Family & Taxon & $\begin{array}{l}\text { Seed- } \\
\text { bank }\end{array}$ & $\begin{array}{l}\text { Filled } \\
\text { seeds } \\
(\%)\end{array}$ & Pretreatment & $\begin{array}{l}\text { Temperature } \\
\left({ }^{\circ} \mathrm{C}\right)\end{array}$ & $\begin{array}{l}\text { Photo- } \\
\text { period } \\
(\mathrm{L} / \mathrm{D} ; \mathrm{h})\end{array}$ & $\begin{array}{l}\text { Germination } \\
(\%)\end{array}$ & $\begin{array}{l}\text { Dormancy } \\
\text { Index } \\
\text { (DI) }\end{array}$ \\
\hline & & MSB & 95 & & 20 & $8 / 16$ & 95 & 0.05 \\
\hline \multirow[t]{2}{*}{ Cactaceae } & $\begin{array}{l}\text { Ferocactus recurvus } \\
\text { (Karw. ex Pfeiff) } \\
\text { N.P. Taylor }\end{array}$ & Fes-I & & & 30 & $12 / 12$ & 70.0 & 0.2 \\
\hline & & MSB & 91 & & & & & \\
\hline \multirow[t]{2}{*}{ Cactaceae } & $\begin{array}{l}\text { Myrtillocactus } \\
\text { geometrizans } \\
\text { (Mart. ex Pfeiff) } \\
\text { Console }\end{array}$ & Fes-I & & & 30 & $12 / 12$ & 70.0 & 0.2 \\
\hline & & MSB & 68 & & & & & \\
\hline \multirow[t]{2}{*}{ Cactaceae } & $\begin{array}{l}\text { Opuntia decumbens } \\
\text { Salm-Dyck }\end{array}$ & Fes-I & & & 30 & $12 / 12$ & 30.0 & 0.7 \\
\hline & & MSB & 95 & & & & & \\
\hline Cactaceae & $\begin{array}{l}\text { Opuntia depressa } \\
\text { Rose }\end{array}$ & Fes-I & & & 30 & $12 / 12$ & 23.3 & 0.8 \\
\hline \multirow[t]{2}{*}{ Cactaceae } & $\begin{array}{l}\text { Opuntia pilifera } \\
\text { F.A.C. Weber }\end{array}$ & Fes-I & & & 30 & $12 / 12$ & 65.0 & 0.4 \\
\hline & & MSB & 95 & & & & & \\
\hline Cactaceae & $\begin{array}{l}\text { Opuntia velutina } \\
\text { F.A.C. Weber }\end{array}$ & Fes-I & & & 30 & $12 / 12$ & 23.3 & 0.8 \\
\hline Cactaceae & $\begin{array}{l}\text { Pachycereus weberi } \\
\text { (J.M. Coult) } \\
\text { Backeb. }\end{array}$ & Fes-I & & & 30 & $12 / 12$ & 81.7 & 0.2 \\
\hline Cactaceae & $\begin{array}{l}\text { Polaskia chichipe } \\
\text { (Gosselin) } \\
\text { Backeb. }\end{array}$ & Fes-I & & & 30 & $12 / 12$ & 98.2 & 0.0 \\
\hline Cactaceae & $\begin{array}{l}\text { Stenocereus } \\
\text { pruinosus (Otto ex } \\
\text { Pfeiff.) Buxb. }\end{array}$ & $\begin{array}{c}\text { Fes-I } \\
\text { I }\end{array}$ & & & 30 & $12 / 12$ & 90.0 & 0.0 \\
\hline \multirow[t]{2}{*}{ Cactaceae } & $\begin{array}{l}\text { Stenocereus } \\
\text { stellatus (Pfeiff.) } \\
\text { Riccob. }\end{array}$ & Fes-I & & & 30 & $12 / 12$ & 100.0 & 0.0 \\
\hline & & MSB & 89 & & & & & \\
\hline Cannabaceae & Celtis pallida Torr. & Fes-I & & & 30 & $12 / 12$ & 70.0 & 0.3 \\
\hline Cannabaceae & $\begin{array}{l}\text { Celtis iguanaea } \\
\text { (Jacq.) Sarg. }\end{array}$ & MSB & 95 & & $35 / 20$ & $8 / 16$ & 79 & 0.21 \\
\hline Celastraceae & $\begin{array}{l}\text { Schaefferia } \\
\text { stenophylla } \\
\text { Standl. }\end{array}$ & MSB & 85 & & $35 / 20$ & $8 / 16$ & 93 & 0.07 \\
\hline Compositae & $\begin{array}{l}\text { Acourtia oxylepis } \\
\text { (A. Gray) Reveal } \\
\text { et R.M.King }\end{array}$ & MSB & 100 & & $15-25$ & $8 / 16$ & 100 & 0 \\
\hline \multirow[t]{2}{*}{ Compositae } & $\begin{array}{l}\text { Flaveria cronquistii } \\
\text { A.M. Powell }\end{array}$ & Fes-I & & & 30 & $12 / 12$ & 59.6 & 0.4 \\
\hline & & MSB & 100 & & $20-25$ & $8 / 16$ & 100 & 0 \\
\hline Compositae & $\begin{array}{l}\text { Flaveria } \\
\quad \text { ramosissima Klatt }\end{array}$ & MSB & 95 & & $35 / 20$ & $8 / 16$ & 95 & 0.05 \\
\hline
\end{tabular}




\begin{tabular}{|c|c|c|c|c|c|c|c|c|}
\hline Family & Taxon & $\begin{array}{l}\text { Seed- } \\
\text { bank }\end{array}$ & $\begin{array}{l}\text { Filled } \\
\text { seeds } \\
(\%)\end{array}$ & Pretreatment & $\begin{array}{l}\text { Temperature } \\
\left({ }^{\circ} \mathrm{C}\right)\end{array}$ & $\begin{array}{l}\text { Photo- } \\
\text { period } \\
(\mathrm{L} / \mathrm{D} ; \mathrm{h})\end{array}$ & $\begin{array}{l}\text { Germination } \\
(\%)\end{array}$ & $\begin{array}{l}\text { Dormancy } \\
\text { Index } \\
\text { (DI) }\end{array}$ \\
\hline \multirow[t]{2}{*}{ Compositae } & $\begin{array}{l}\text { Gymnolaena } \\
\text { oaxacana } \\
\text { (Greenm.) Rydb. }\end{array}$ & Fes-I & & & 30 & $12 / 12$ & 38.3 & 0.4 \\
\hline & & MSB & 20 & & 25 & $8 / 16$ & 75 & 0.25 \\
\hline Compositae & $\begin{array}{l}\text { Parthenium } \\
\text { hysterophorus L. }\end{array}$ & MSB & 100 & & 20 & $8 / 16$ & 90 & 0.1 \\
\hline Compositae & $\begin{array}{l}\text { Porophyllum } \\
\text { ruderale (Jacq.) } \\
\text { Cass. } \\
\text { subsp. } \\
\text { macrocephalum } \\
\text { (DC.) R.R. } \\
\text { Johnson }\end{array}$ & MSB & 100 & & & & & \\
\hline \multirow[t]{2}{*}{ Compositae } & $\begin{array}{l}\text { Sanvitalia } \\
\quad \text { procumbens Lam. }\end{array}$ & Fes-I & & & 30 & $12 / 12$ & 50.0 & 0.5 \\
\hline & & MSB & 100 & & & & & \\
\hline Compositae & $\begin{array}{l}\text { Viguiera dentata } \\
\text { (Cav.) Spreng. }\end{array}$ & MSB & 100 & & 15 & $8 / 16$ & 100 & 0 \\
\hline \multirow[t]{2}{*}{ Compositae } & $\begin{array}{l}\text { Zinnia peruviana } \\
\text { (L.) L. }\end{array}$ & Fes-I & & & 30 & $12 / 12$ & 33.3 & 0.7 \\
\hline & & MSB & 65 & & & & & \\
\hline \multirow[t]{2}{*}{ Convolvulaceae } & $\begin{array}{l}\text { Ipomoea pauciflora } \\
\text { M. Martens et } \\
\text { Galeotti }\end{array}$ & Fes-I & & & 30 & $12 / 12$ & 100.0 & 0.0 \\
\hline & & MSB & 90 & $\begin{array}{l}\text { Chipped with } \\
\text { scalpel }\end{array}$ & $20-25$ & $8 / 16$ & 100 & 0 \\
\hline Cucurbitaceae & $\begin{array}{l}\text { Cucumis dipsaceus } \\
\text { Ehrenb. ex Spach }\end{array}$ & Fes-I & & & 30 & $12 / 12$ & 68.3 & 0.1 \\
\hline \multirow[t]{2}{*}{ Euphorbiaceae } & $\begin{array}{l}\text { Cnidoscolus } \\
\text { tehuacanensis } \\
\text { Breckon }\end{array}$ & Fes-I & & & 30 & $12 / 12$ & 41.7 & 0.5 \\
\hline & & MSB & 100 & & & & & \\
\hline Euphorbiaceae & $\begin{array}{l}\text { Croton mazapensis } \\
\text { Lund }\end{array}$ & Fes-I & & & 30 & $12 / 12$ & 31.3 & 0.6 \\
\hline \multirow[t]{2}{*}{ Euphorbiaceae } & $\begin{array}{l}\text { Jatropha } \\
\quad \text { neopauciflora Pax }\end{array}$ & Fes-I & & & 30 & $12 / 12$ & 4.4 & 0.0 \\
\hline & & MSB & 70 & Filed & 25 & $8 / 16$ & 43 & 0.57 \\
\hline \multirow[t]{2}{*}{ Euphorbiaceae } & $\begin{array}{l}\text { Jatropha rzedowskii } \\
\text { J. Jiménez Ram. }\end{array}$ & Fes-I & & & 30 & $12 / 12$ & 4.7 & 1.0 \\
\hline & & MSB & 70 & & 25 & $8 / 16$ & 100 & 0 \\
\hline \multirow[t]{2}{*}{ Euphorbiaceae } & $\begin{array}{l}\text { Manihot pauciflora } \\
\text { Brandegee }\end{array}$ & Fes-I & & & 30 & $12 / 12$ & 60.0 & 0.4 \\
\hline & & MSB & 90 & & 25 & $8 / 16$ & 90 & 0.1 \\
\hline \multirow[t]{2}{*}{ Fouqueriaceae } & $\begin{array}{l}\text { Fouquieria formosa } \\
\text { Kunth }\end{array}$ & Fes-I & & & 30 & $12 / 12$ & 91.4 & 0.1 \\
\hline & & MSB & 94 & & $15-25$ & $8 / 16$ & 100 & 0 \\
\hline Hernandiaceae & $\begin{array}{l}\text { Gyrocarpus mocinoi } \\
\text { Espejo }\end{array}$ & Fes-I & & & 30 & $12 / 12$ & 18.3 & 0.8 \\
\hline
\end{tabular}




\begin{tabular}{|c|c|c|c|c|c|c|c|c|}
\hline Family & Taxon & $\begin{array}{l}\text { Seed- } \\
\text { bank }\end{array}$ & $\begin{array}{l}\text { Filled } \\
\text { seeds } \\
(\%)\end{array}$ & Pretreatment & $\begin{array}{l}\text { Temperature } \\
\left({ }^{\circ} \mathrm{C}\right)\end{array}$ & $\begin{array}{l}\text { Photo- } \\
\text { period } \\
(\mathrm{L} / \mathrm{D} ; \mathrm{h})\end{array}$ & $\begin{array}{l}\text { Germination } \\
(\%)\end{array}$ & $\begin{array}{l}\text { Dormancy } \\
\text { Index } \\
\text { (DI) }\end{array}$ \\
\hline & & MSB & 90 & $\begin{array}{l}\text { Chip both radicle } \\
\text { tip and cotyledon } \\
\text { ends of seed }\end{array}$ & $20-25$ & $8 / 16$ & 100 & 0 \\
\hline Leguminosae & $\begin{array}{l}\text { Acacia angustissima } \\
\text { (Mill.) Kuntze }\end{array}$ & Fes-I & & Chipping & 30 & $12 / 12$ & 100.0 & 0.0 \\
\hline \multirow[t]{2}{*}{ Leguminosae } & $\begin{array}{l}\text { Acacia } \\
\text { cochliacantha } \\
\text { Humb. et Bonpl. } \\
\text { ex Willd. }\end{array}$ & Fes-I & & Chipping & 30 & $12 / 12$ & 100.0 & 0.0 \\
\hline & & MSB & 96 & $\begin{array}{l}\text { Chipped with } \\
\text { scalpel }\end{array}$ & $20-25$ & $8 / 16$ & 100 & 0 \\
\hline Leguminosae & $\begin{array}{l}\text { Acacia compacta } \\
\text { Rose }\end{array}$ & MSB & 50 & $\begin{array}{l}\text { Chipped with } \\
\text { scalpel }\end{array}$ & $15-25$ & $8 / 16$ & 100 & 0 \\
\hline \multirow[t]{2}{*}{ Leguminosae } & $\begin{array}{l}\text { Acacia farnesiana } \\
\text { (L.) Willd. }\end{array}$ & Fes-I & & Chipping & 30 & $12 / 12$ & 81.7 & 0.0 \\
\hline & & MSB & 66 & $\begin{array}{l}\text { Chipped with } \\
\text { scalpel }\end{array}$ & 20 & $8 / 16$ & 100 & 0 \\
\hline \multirow[t]{2}{*}{ Leguminosae } & $\begin{array}{l}\text { Caesalpinia } \\
\text { melanadenia } \\
\text { (Rose) Standl. }\end{array}$ & MSB & 100 & $\begin{array}{l}\text { Chipped with } \\
\text { scalpel }\end{array}$ & $15-20$ & $8 / 16$ & 70 & 0.3 \\
\hline & & Fes-I & & Chipping & 30 & $12 / 12$ & 78.3 & 0.0 \\
\hline \multirow[t]{2}{*}{ Leguminosae } & $\begin{array}{l}\text { Coursetia caribaea } \\
\text { (Jacq.) Lavin }\end{array}$ & Fes-I & & Chipping & 30 & $12 / 12$ & 0.0 & 1.0 \\
\hline & & MSB & 100 & $\begin{array}{l}\text { Chipped with } \\
\text { scalpel }\end{array}$ & $20-25$ & $8 / 16$ & 100 & 0 \\
\hline \multirow[t]{2}{*}{ Leguminosae } & $\begin{array}{l}\text { Coursetia } \\
\text { glandulosa A. } \\
\text { Gray }\end{array}$ & Fes-I & & Chipping & 30 & $12 / 12$ & 94.6 & 0.1 \\
\hline & & MSB & 100 & $\begin{array}{l}\text { Chipped with } \\
\text { scalpel }\end{array}$ & 25 & $8 / 16$ & 100 & 0 \\
\hline Leguminosae & $\begin{array}{l}\text { Enterolobium } \\
\text { cyclocarpum } \\
\text { (Jacq.) Griseb. }\end{array}$ & Fes-I & & Chipping & 30 & $12 / 12$ & 100.0 & 0.0 \\
\hline \multirow[t]{2}{*}{ Leguminosae } & $\begin{array}{l}\text { Indigofera conzattii } \\
\text { Rose }\end{array}$ & Fes-I & & Chipping & 30 & $12 / 12$ & 76.7 & 0.0 \\
\hline & & MSB & 100 & $\begin{array}{l}\text { Chipped with } \\
\text { scalpel }\end{array}$ & $20-25$ & $8 / 16$ & 100 & 0 \\
\hline Leguminosae & $\begin{array}{l}\text { Leucaena } \\
\text { leucocephala } \\
\text { (Lam.) de Wit }\end{array}$ & MSB & 100 & $\begin{array}{l}\text { Chipped with } \\
\text { scalpel }\end{array}$ & 15 & $8 / 16$ & 90 & 0.1 \\
\hline \multirow[t]{2}{*}{ Leguminosae } & $\begin{array}{l}\text { Mimosa luisana } \\
\text { Brandegee }\end{array}$ & Fes-I & & Chipping & 30 & $12 / 12$ & 88.3 & 0.0 \\
\hline & & MSB & 100 & $\begin{array}{l}\text { Chipped with } \\
\text { scalpel }\end{array}$ & 20 & $8 / 16$ & 100 & 0 \\
\hline \multirow[t]{2}{*}{ Leguminosae } & $\begin{array}{l}\text { Mimosa polyantha } \\
\text { Benth. }\end{array}$ & Fes-I & & Chipping & 30 & $12 / 12$ & 3.3 & 1.0 \\
\hline & & MSB & 95 & $\begin{array}{l}\text { Chipped with } \\
\text { scalpel }\end{array}$ & 20 & $8 / 16$ & 100 & 0 \\
\hline
\end{tabular}




\begin{tabular}{|c|c|c|c|c|c|c|c|c|}
\hline Family & Taxon & $\begin{array}{l}\text { Seed- } \\
\text { bank }\end{array}$ & $\begin{array}{l}\text { Filled } \\
\text { seeds } \\
(\%)\end{array}$ & Pretreatment & $\begin{array}{l}\text { Temperature } \\
\left({ }^{\circ} \mathrm{C}\right)\end{array}$ & $\begin{array}{l}\text { Photo- } \\
\text { period } \\
(\mathrm{L} / \mathrm{D} ; \mathrm{h})\end{array}$ & $\begin{array}{l}\text { Germination } \\
(\%)\end{array}$ & $\begin{array}{l}\text { Dormancy } \\
\text { Index } \\
\text { (DI) }\end{array}$ \\
\hline \multirow[t]{2}{*}{ Leguminosae } & $\begin{array}{l}\text { Parkinsonia } \\
\text { praecox } \\
\text { (Ruiz et Pav.) } \\
\text { Hawkins }\end{array}$ & Fes-I & & Chipping & 30 & $12 / 12$ & 100.0 & 0.0 \\
\hline & & MSB & 90 & $\begin{array}{l}\text { Chipped with } \\
\text { scalpel }\end{array}$ & $20-25$ & $8 / 16$ & 100 & 0 \\
\hline Leguminosae & $\begin{array}{l}\text { Pithecellobium } \\
\text { dulce (Roxb.) } \\
\text { Benth. }\end{array}$ & Fes-I & & Chipping & 30 & $12 / 12$ & 100.0 & 0.0 \\
\hline \multirow[t]{2}{*}{ Leguminosae } & $\begin{array}{l}\text { Prosopis laevigata } \\
\text { (Willd.) M.C. } \\
\text { Johnst. }\end{array}$ & Fes-I & & Chipping & 30 & $12 / 12$ & 100.0 & 0.0 \\
\hline & & MSB & 40 & $\begin{array}{l}\text { Covering structure } \\
\text { removed and seed } \\
\text { coat chipped }\end{array}$ & 25 & $8 / 16$ & 100 & 0 \\
\hline \multirow[t]{2}{*}{ Leguminosae } & $\begin{array}{l}\text { Senna wislizeni } \\
\text { (Rose) H.S. Irwin } \\
\text { et Barneby }\end{array}$ & Fes-I & & Chipping & 30 & $12 / 12$ & 100.0 & 0.0 \\
\hline & & MSB & 100 & $\begin{array}{l}\text { Chipped with } \\
\text { scalpel }\end{array}$ & 25 & $8 / 16$ & 100 & 0 \\
\hline Loasaceae & $\begin{array}{l}\text { Mentzelia hispida } \\
\text { Willd. }\end{array}$ & Fes-I & & & 30 & $12 / 12$ & 13.8 & 0.9 \\
\hline Malvaceae & $\begin{array}{l}\text { Allowissadula rosei } \\
\text { (R.E.Fr.) D.M. } \\
\text { Bates }\end{array}$ & MSB & 90 & $\begin{array}{l}\text { Chipped with } \\
\text { scalpel }\end{array}$ & 25 & $8 / 16$ & 100 & 0 \\
\hline \multirow[t]{2}{*}{ Malvaceae } & $\begin{array}{l}\text { Ceiba aesculifolia } \\
\text { (Rose) P.E. Gibbs } \\
\text { et Semir }\end{array}$ & Fes-I & & & 30 & $12 / 12$ & 46.2 & 0.4 \\
\hline & & MSB & 70 & & 20 & $8 / 16$ & 45 & 0.55 \\
\hline Malvaceae & $\begin{array}{l}\text { Guazuma ulmifolia } \\
\text { Lam. }\end{array}$ & MSB & 84 & $\begin{array}{l}\text { Chipped with } \\
\text { scalpel }\end{array}$ & 30 & $8 / 16$ & 100 & 0 \\
\hline Malvaceae & $\begin{array}{l}\text { Heliocarpus } \\
\text { terebinthinaceus } \\
\text { (DC.) Hochr. }\end{array}$ & MSB & 40 & & & & & \\
\hline Malvaceae & $\begin{array}{l}\text { Heliocarpus } \\
\text { terebinthinaceus } \\
\mathrm{L} .\end{array}$ & Fes-I & & & 30 & $12 / 12$ & 2.2 & 0.0 \\
\hline Malvaceae & $\begin{array}{l}\text { Herissantia crispa } \\
\text { (L.) Brizicky }\end{array}$ & Fes-I & & & 30 & $12 / 12$ & 1.7 & 1.0 \\
\hline \multirow[t]{2}{*}{ Malvaceae } & $\begin{array}{l}\text { Melochia tomentosa } \\
\text { L. }\end{array}$ & Fes-I & & & 30 & $12 / 12$ & 0.0 & 1.0 \\
\hline & & MSB & 95 & $\begin{array}{l}\text { Chipped with } \\
\text { scalpel }\end{array}$ & 20 & $8 / 16$ & 100 & 0 \\
\hline Malvaceae & Waltheria indica $\mathrm{L}$. & Fes-I & & & 30 & $12 / 12$ & 5.4 & 0.9 \\
\hline Martyniaceae & $\begin{array}{l}\text { Proboscidea } \\
\text { fragrans (Lindl.) } \\
\text { Decne. }\end{array}$ & MSB & 100 & & & & & \\
\hline Papaveraceae & $\begin{array}{l}\text { Argemone mexicana } \\
\mathrm{L} .\end{array}$ & Fes-I & & & 30 & $12 / 12$ & 1.7 & 1.0 \\
\hline
\end{tabular}




\begin{tabular}{|c|c|c|c|c|c|c|c|c|}
\hline Family & Taxon & $\begin{array}{l}\text { Seed- } \\
\text { bank }\end{array}$ & $\begin{array}{l}\text { Filled } \\
\text { seeds } \\
(\%)\end{array}$ & Pretreatment & $\begin{array}{l}\text { Temperature } \\
\left({ }^{\circ} \mathrm{C}\right)\end{array}$ & $\begin{array}{l}\text { Photo- } \\
\text { period } \\
(\mathrm{L} / \mathrm{D} ; \mathrm{h})\end{array}$ & $\begin{array}{l}\text { Germination } \\
(\%)\end{array}$ & $\begin{array}{l}\text { Dormancy } \\
\text { Index } \\
\text { (DI) }\end{array}$ \\
\hline Passifloraceae & Passiflora foetida $\mathrm{L}$. & Fes-I & & & 30 & $12 / 12$ & 0.0 & 1.0 \\
\hline \multirow[t]{2}{*}{ Rhamnaceae } & $\begin{array}{l}\text { Karwinskia mollis } \\
\text { Schldl. }\end{array}$ & Fes-I & & & 30 & $12 / 12$ & 27.9 & 0.7 \\
\hline & & MSB & 83 & $\begin{array}{l}\text { Covering structure } \\
\text { partially removed }\end{array}$ & 15 & $8 / 16$ & 45 & 0.55 \\
\hline Rhamnaceae & $\begin{array}{l}\text { Ziziphus mexicana } \\
\text { Rose }\end{array}$ & Fes-I & & & 30 & $12 / 12$ & 10.0 & 0.9 \\
\hline Rhamnaceae & $\begin{array}{l}\text { Ziziphus } \\
\text { pedunculata } \\
\text { (Brandegee) } \\
\text { Standl. }\end{array}$ & MSB & 83 & $\begin{array}{l}\text { Covering structure } \\
\text { removed or } \\
\text { chipped with } \\
\text { scalpel }\end{array}$ & $20-25$ & $8 / 16$ & 45 & 0.55 \\
\hline Rubiaceae & $\begin{array}{l}\text { Randia nelsonii } \\
\text { Greenm. }\end{array}$ & MSB & 90 & & 25 & $8 / 16$ & 100 & 0 \\
\hline Rubiaceae & $\begin{array}{l}\text { Randia thurberi } \\
\text { S.Watson }\end{array}$ & Fes-I & & & 30 & $12 / 12$ & 100.0 & 0.0 \\
\hline \multirow[t]{2}{*}{ Sapindaceae } & $\begin{array}{l}\text { Cardiospermum } \\
\text { halicacabum L. }\end{array}$ & Fes-I & & & 30 & $12 / 12$ & 0.0 & 1.0 \\
\hline & & MSB & 60 & $\begin{array}{l}\text { Covering structure } \\
\text { partially removed }\end{array}$ & $35 / 20$ & $8 / 16$ & 100 & 0 \\
\hline \multirow[t]{2}{*}{ Simaroubaceae } & $\begin{array}{l}\text { Castela tortuosa } \\
\text { Liebm. }\end{array}$ & Fes-I & & & 30 & $12 / 12$ & 50.0 & 0.5 \\
\hline & & MSB & 90 & GA3 $250 \mathrm{mg} / \mathrm{L}$ & 25 & $8 / 16$ & 82 & 0.18 \\
\hline Solanaceae & $\begin{array}{l}\text { Datura innoxia } \\
\text { Mill. }\end{array}$ & Fes-I & & & 30 & $12 / 12$ & 23.9 & 0.7 \\
\hline Solanaceae & $\begin{array}{l}\text { Nicotiana glauca } \\
\text { Graham }\end{array}$ & MSB & 95 & & & & & \\
\hline Solanaceae & $\begin{array}{l}\text { Solanum } \\
\text { elaeagnifolium } \\
\text { Cav. }\end{array}$ & MSB & 75 & & & & & \\
\hline Solanaceae & $\begin{array}{l}\text { Solanum houstonii } \\
\text { Martyn }\end{array}$ & MSB & 100 & $\begin{array}{l}\text { GA3 } 250 \mathrm{mg} / \\
\text { 1 + Chipped with } \\
\text { scalpel }\end{array}$ & $35 / 20$ & $8 / 16$ & 75 & 0.25 \\
\hline Solanaceae & $\begin{array}{l}\text { Solanum } \\
\text { lanceolatum Cav. }\end{array}$ & Fes-I & & & 30 & $12 / 12$ & 5.4 & 0.9 \\
\hline Solanaceae & $\begin{array}{l}\text { Solanum rostratum } \\
\text { Dunal }\end{array}$ & MSB & 80 & & & & & \\
\hline Solanaceae & $\begin{array}{l}\text { Solanum } \\
\quad \text { tridynamum Dunal }\end{array}$ & Fes-I & & & 30 & $12 / 12$ & 10.3 & 0.9 \\
\hline \multirow[t]{2}{*}{ Verbenaceae } & Lantana camara $\mathrm{L}$. & Fes-I & & & 30 & $12 / 12$ & 43.3 & 0.6 \\
\hline & & MSB & 50 & & & & & \\
\hline \multirow[t]{2}{*}{ Verbenaceae } & $\begin{array}{l}\text { Lippia graveolens } \\
\text { Kunth }\end{array}$ & Fes-I & & & 30 & $12 / 12$ & 51.4 & 0.5 \\
\hline & & MSB & 95 & & 25 & $8 / 16$ & 40 & 0.6 \\
\hline
\end{tabular}




\section{References}

Ågren J (1996) Population size, pollinator limitation, and seed set in the self-incompatible herb Lythrum salicaria. Ecology 77:1779-1790

Alui Konan A, Ballo Koffi C, Yapi A, Kouadio Konan-Kan H, Kouadio Koffi P, Touré N, N'Guessan Kouamé A, Kwadjo Koffi E, Yao-Kouamé A (2013) Improvement tests on the germination in Lippia multiflora: influence of some factors related to soil on germination and seedling development. Asian J Agric Rural Dev 3(1):18-29

Álvarez-Espino R, Godínez-Álvarez H, De la Torre-Almaráz R (2014) Seed banking in the columnar cactus Steneocereus stellatus: distribution, density and longevity of seeds. Seed Sci Res 24(4):315-320

Alves RRN, Rosa IML (2007) Biodiversity, traditional medicine and public health: where do they meet? J Ethnobiol Ethnomed 3:14

Baskin CC, Baskin JM (2014) Seeds. Ecology, biogeography, and evolution of dormancy and germination, 2nd edn. Academic Press, San Diego

Baskin CC, Thompson K, Baskin JM (2006) Mistakes in germination ecology and how to avoid them. Seed Sci Res 16:165-168

Blanckaert I, Swennen RL, Paredes Flores M, Rosas López R, Lira Saade R (2004) Floristic composition, plant uses and management prctices in homegardens of San Rafael Coxcatlán, Valley of Thuacán-Cuicatlán, Mexico. J Arid Environ 57:39-62

Blanckaert I, Vancraeynest K, Swennen RL, Espinosa-García FJ, Piñero D, Lira-Saade R (2007) Non-crop resources and the role of indigenous knowledge in semi-arid production of Mexico. Agric Ecosyst Environ 119:39-48

Caballero J, Casas A, Cortés L, Mapes C (1998) Patrones en el conocimiento, uso y manejo de plantas en pueblos de México. Estudios Atacameños 16:1-15

Camargo-Ricalde SL, Dhillion Shivcharn S, Grether R (2002) Community structure of endemic Mimosa species and environmental heterogeneity in a semi-arid Mexican valley. J Veg Sci 13:693-704

Casas A, Viveros JL, Caballero J (1994) Etnobotánica Mixteca: Sociedad, recursos naturales y subsistencia en la Montaña de Guerrero. Consejo Nacional Para la Cultura y las Artes/ Instituto Nacional Indigenista, Mexico City

Casas A, Valiente-Banuet A, Viveros JL, Caballero J, Cortés L, Dávila P, Lira R, Rodríguez-Arévalo I (2001) Plant resources of the Tehuacán-Cuicatlán Valley, México. Econ Bot 55:129-166

Castañeda-Álvarez NP, Khoury CK, Achicanoy HA, Bernau V, Dempewolf H, Eastwood RJ, Guarino L, Harker RH, Jarvis A, Maxted N, Müller JV, Ramirez Villegas J, Sosa CC, Struik PC, Vincent H, Toll J (2016) Global conservation priorities for crop wild relatives. Nat Plants. doi:10.1038/ nplants.2016.22

CBD (2002) Global strategy for plant conservation. The Secretariat of the Convention on Biological Diversity, Montreal

Cook FEM (1995) Economic botany data collection standard. Royal Botanic Gardens, Kew
Dávila P, Arizmendi MC, Valiente-Banuet A, Villaseñor JL, Casas A, Lira R (2002) Biological diversity in the TehuacánCuicatlán Valley, Mexico. Biodivers Conserv 11:421-442

ENSCONET (2009) ENSCONET seed collecting manual for wild species. http://www.luomus.fi. Accessed 2 Aug 2015

Fenner M, Thompson K (2005) The ecology of seeds. Cambridge University Press, Cambridge

Fischer M, Matthies D (1998) Effects of population size on performance in the rare plant Gentianella germanica. J Ecol 86:195-203

Galíndez G, Seal C, Daws MI, Lindow L, Ortega-Baes P, Pritchard HW (2016) Alternating temperature combined with darkness resets base temperature for germination $(\mathrm{Tb})$ in photoblastic seeds of Lippia and Aloysia (Verbenaceae). Plant Biol. doi: 10.1111/plb.12449

Garcia-Chávez JH, Montaña C, Perroni Y, Sosa VJ, GarcíaLicona JB (2014) The relative importance of solar radiation and soil origin in cactus seedling survivorship at two spatial scales: plant association and microhabitat. J Veg Sci 25:668-680

Godefroid S, Van de Vyver A, Vanderborght T (2010) Germination capacity and viability of threatened species collections in seed banks. Biodivers Conserv 19:1365-1383

Gonzalez-Benito ME, Perez-Ruiz C (1992) Cryopreservation of Quercus faginea embryonic axes. Cryobiology 29(6):685-690

Hay FR, Probert RJ (2013) Advances in seed conservation of wild plant species: a review of recent research. Conserv Physiol. doi:10.1093/conphys/cot030

Hernández-Xolocotzi E (1993) Aspects of plant domestication in Mexico: a personal view. In: Ramamoorthy TP, Bye R, Lot A, Fa J (eds) Biological diversity of Mexico, origins and distribution. Oxford University Press, New York, pp 733-753

Hong TD, Linington S, Ellis RH (1998) Compendium of information on seed storage behaviour, vol I. Royal Botanic Gardens, Kew

Iriondo JM, Pérez C (1999) Propagation from seeds and seed preservation. In: Bowes BG (ed) A colour atlas of plant propagation and conservation. Manson Publishing, London, pp 46-57

IUCN (2015) The IUCN red list of threatened species. Version 2014.3. www.iucnredlist.org. Downloaded on 13 Feb 2015

Jacquemyn H, Brys R, Hermy M (2002) Patch occupancy, population size and reproductive success of a forest herb (Primula elatior) in a fragmented landscape. Oecologia 130:617-625

Jankowska-Blaszczuk M, Daws MI (2007) Impact of red: far red ratios on germination of temperate forest herbs in relation to shade tolerance, seed mass and persistence in the soil. Funct Ecol 21:1055-1062

León-Lobos P, Way M, Davila Aranda P, Lima-Junior M (2012) The role of ex situ seed banks in the conservation of plant diversity and in ecological restoration in Latin America. Plant Ecol Divers 5(2):245-258

Li D-Z, Pritchard HW (2009) The science and economics of ex situ plant conservation. Trends Plant Sci 14:614-621

Linington SH (2003) The Design of Seed Banks. In: Smith RD, Dickie JB, Linington SH, Pritchard HW, Probert RJ (eds) 
Seed conservation: turning science into practice. Royal Botanic Gardens, Kew, pp 591-636

Lira R, Casas A, Rosas-López R, Paredes-Flores M, PérezNegrón E, Rangel-Landa S, Solís L, Torres I, Dávila P (2009a) Traditional knowledge and useful plant richness in the Tehuacán-Cuicatlán Valley, Mexico. Econ Bot 63(3):271-287

Lira R, Téllez O, Dávila P (2009b) The effects of climate change on the geographic distribution of Mexican wild relatives of domesticated Cucurbitaceae. Genet Resour Crop Evol 56:691-703

MacNeish RS (1992) The origins of agriculture and settled life. University of Oklahoma Press, Norman

Mandujano MC, Flores-Martínez A, Golubov J, Excurra E (2002) Spatial distribution of three globose cacti in relation to different nurse-plant canopies and bare areas. Southwest Nat 47(2):162-168

Mata-González R, Meléndez-González R (2005) Growth characteristics of Mexican oregano (Lippia berlandieri Schauer) under salt stress. Southwest Nat 50(1):1-6

Mattana E, Stuppy WH, Fraser R, Waller J, Pritchard HW (2014) Dependency of seed dormancy types on embryo traits and environmental conditions in Ribes species. Plant Biol 16:740-747

Medina J (2000) Determinación del vigor y el estado reproductivo de Stenocereus stellatus (Cactaceae) a lo largo de una cronosecuencia edáfica en un abanico aluvial en Coxcatlán, Valle de Tehuacán, Tésis Profesional, Facultad de Estudios Superiores Iztacala, Universidad Nacional Autónoma de México, México D.F., México

Menges ES, Guerrant EO Jr, Hamzé S (2004) Effects of seed collection on the extinction risk of perennials plants. In: Guerrant EO Jr, Havens K, Maunder M (eds) Ex situ plant conservation. Island Press, London, Supporting species survival in the wild, pp 305-324

Morello-Calles AI, Casas A (2010) Agroforestry systems: restoration of semiarid zones in the Tehuacán-Cuicatlán Valley, Central Mexico. Ecol Restor 28(3):361-368

Newton R, Hay F, Probert RJ (2014) Protocol for comparative seed longevity testing. In: Technical information sheet 01 . Board of Trustees of the Royal Botanic Gardens, Kew, London

Offord CA, Mckensy ML, Cuneo PV (2004) Critical review of threatened species collections in the NSW Seedbank: implications for ex situ conservation of biodiversity. Pac Conserv Biol 10:221-236

Ordõnez-Salanueva CA, Seal CE, Pritchard HW, Orozco-Segovia A, Canales-Martínez M, Flores-Ortiz CM (2015) Cardinal temperatures and thermal time in Polaskia Backeb (Cactaceae) species: effect of projected soil temperature increase and nurse interaction on germination timing. J Arid Environ 115:73-80

Padulosi S, Hodgkin T, Williams JT, Haq N (2002) Underutilized crops: trends, challenges and opportunities in the 21st century. In: Engels JMM, Rao VR, Jackson M (eds) Managing plant genetic diversity. CAB International, Wallingford, pp 323-338

Pardo J (2001) Diagnóstico de las plantas silvestres, arvenses y ruderales que son empleadas como alimentos por habitantes de cuatro localidades del Valle de Tehuacán-Cuicatlán. Tésis Profesional, Facultad de Estudios Superiores
Iztacala, Universidad Nacional Autónoma de México, México D.F., México

Pence VC (2013) In vitro methods and the challenge of exceptional species for target 8 of the global strategy for plant conservation. Ann Mo Bot Gard 99(2):214-220

Pérez-García F, González-Benito ME, Gómez-Campo C (2007) High viability recored in ultra-dry seeds of 37 species of Brassicaceae after almost 40 years of storage. Seed Sci Technol 35:143-153

Pimm SL, Russel GJ, Gittleman JL, Brooks TM (1995) The future of biodiversity. Science 269:347-350

Probert RJ (2000) The role of temperature in the regulation of seed dormancy and germination. In: Fenner M (ed) Seeds: the ecology of regeneration in plant communities, 2nd edn. CAB International, Wallingford, pp 261-292

Probert RJ, Daws MI, Hay FR (2009) Ecological correlates of ex situ seed longevity: a comparative study on 195 species. Ann Bot 104:57-69

R Development Core Team (2011) R: a language and environment for statistical computing. R Foundation for Statistical Computing, Vienna, Austria. http://www.R-project.org

Ramos-Ordoñez MF, Márquez-Guzman J, del Coro Arizmendi M (2008) Parthenocarpy and seed predation by insects in Bursera morelensis. Ann Bot 102:713-722

Ramos-Ordoñez MF, del Coro Arizmendi M, Márquez-Guzmán J (2012) The fruit of Bursera: structure, maturation and parthenocarpy. AoB Plants pls027d. doi:10.193/aobpla/pls027

Roberts EH (1973) Predicting the storage life of seeds. Seed Sci Technol 1:499-514

Roberts EH (1988) Temperature and seed germination. In: Long SP, Woodward FI (eds) Plants and temperature. Symposia of the society of experimental biology. Company of Biologists, Cambridge, pp 109-132

Rosas R (2003) Estudios Etnobotánicos de San Rafael-Coxcatlán. Tésis Profesional, Facultad de Estudios Superiores Iztacala, Universidad Nacional Autónoma de México, México D.F., México

Royal Botanic Gardens Kew (2014) Seed information database (SID). Version 7.1. http://data.kew.org/sid/. Accessed 03 Apr 2014

Rzedowski J (1993) Diversity and origins of the phanerogamic flora of Mexico. In: Ramamoorthy TP, Bye R, Lot A, Fa J (eds) Biological diversity of Mexico, origins and distribution. Oxford University Press, New York, pp 129-144

Terry J, Probert RJ, Linington SH (2003) Processing and maintenance of the millennium seed bank collections. In: Smith RD, Dickie JB, Linington SH, Pritchard HW, Probert RJ (eds) Seed Conservation: turning science into practice. Royal Botanic Gardens, Kew, pp 307-325

The Plant List (2013) Version 1.1. Published on the internet; http://www.theplantlist.org/. Accessed 3 Apr 2014

Toledo VM, Rzedowski J, Villalobos J (1997) Regional overview: Middle America. In: Davis SD, Heywood VH, Herrera-MacBryde O, Villa-Lobos J, Hamilton AC (eds) Centres of plant diversity. A guide and strategy for their conservation, vol 3: the Americas, vol. IUCN Publications Unit, Cambridge, pp 97-124

Ulian T, Sacande M, Hudson A, Mattana E (2016) Conservation of indigenous plants to support community livelihoods: the MGU-Useful Plants Project. J Environ Plann Man (in press). doi:10.1080/09640568.2016.1166101 
Valiente-Banuet A, Bolongaro-Crevenna A, Briones O, Excurra E, Rosas M, Nuñez H, Barnard G, Vazquez E (1991) Spatial realtionships between cacti and nurse shrubs in a semi-arid environment in central Mexico. J Veg Sci 2:15-20

Vandelook F, Janssens SB, Probert RJ (2012) Relative embryo length as an adaptation to habitat and life cycle in Apiaceae. New Phytol 195:479-487

Way MJ (2003) Collecting seeds from non-domesticated plants for long-term conservation. In: Smith RD, Dickie JB,
Linington SH, Pritchard HW, Probert RJ (eds) Seed conservation: turning science into practice. Royal Botanic Gardens, Kew, pp 163-201

Westengen OT, Jeppson S, Guarino L (2013) Global ex-situ crop diversity conservation and the Svalbard Global Seed Vault: assessing the current status. PLoS One 8(5):e64146

Xia K, Daws MI, Stuppy W, Zhou Z-K, Pritchard HW (2012) Rates of water loss and uptake in recalcitrant fruits of quercus species are determined by pericarp anatomy. PLoS One 7(10):e47368 